\title{
SUPLEMENTAÇÃO DE PROPILENO GLICOL E MONENŞINA SÓDICA PARA VACAS LEITEIRAS NO PERÍODO DE TRANSIÇÃO
}

\author{
SÉRGIO DE OLIVEIRA JUCHEM
}

Médico Veterinário

Orientador : Prof. Dr.Flávio Augusto Portela Santos

Dissertação apresentada à Escola Superior de Agricultura "Luiz de Queiroz" da Universidade de Sảo Paulo, para obtenção do título de Mestre em Agronomia, Área de Concentração: Ciência Animal e Pastagens.

PIR A C I C A B A

Estado de São Paulo - Brasil

Dezembro - 2000 
Juchem, Sérgio de O. Suplementação de propileno glicol e monensina sódica para vacas leiteiras no período de transição. Piracicaba, 2000. 99p.

\section{ERRATA \& CORRIGENDA}

Ficha Catalográfica:

Item 2. onde se lê Mononsina, leia-se Monensina.

\begin{tabular}{ccccc}
\hline p. & item & linha & onde se lê & leia-se \\
\hline xiii & Resumo & 03 & $(\mathrm{P}=0,047)$ & $(\mathrm{P}=0,0047)$ \\
xv & Summary & 19 & $(\mathrm{P}=0,047)$ & $(\mathrm{P}=0.0047)$ \\
59 & Tabela 11 & 06 & Insulina $(\mu \mathrm{mol} / \mathrm{ml})$ & Insulina $(\mu \mathrm{UL} / \mathrm{ml})$ \\
60 & Tabela 13 & 03 & Insulina $(\mu \mathrm{mol} / \mathrm{ml})$ & Insulina $(\mu \mathrm{UI} / \mathrm{ml})$ \\
60 & Tabela 13 & 05 & Insulina $(\mu \mathrm{mol} / \mathrm{ml})$ & Insulina $(\mu \mathrm{UL} / \mathrm{ml})$ \\
\hline
\end{tabular}




\title{
Dados Internacionais de catalogação na Publicação (CIP) DIVISÃO DE BIBLIOTECA E DOCUMENTAÇÃO - Campus "Luiz de Queiroz"/USP
}

\author{
Juchem, Sérgio de Oliveira \\ Suplementação de propileno glicol e monensina sódica para vacas no periodo de \\ transição / Sérgio de Oliveira Juchem. - - Piracicaba, 2000. \\ 99 p. : il. \\ Dissertação (mestrado) - - Escola Superior de Agricultura Luiz de Queiroz, 2000. \\ Bibliografia. \\ 1. Distúrbio metabólico 2. Mononsina 3. Nutrição animal 4. Período pré-parto 5. \\ Reprodução animal 6. Vaca leiteira I. Título
}

CDD 636.2085

Permitida a copha toti on parcial deste documento, desde que citada a fonte -0 autor: 


\title{
Aos meus jovens pais, Marta e Roque Juchem, pelo amor, dedicação e apoio aos filhos durante este longo percurso.
}

\author{
A minha irmã, \\ pelo amor e a amizade.
}

\author{
À Juliana, \\ pelo carinho, incentivo e \\ paciência durante estes três anos.
}

Ao meu Tio, colega e amigo, o Médico Veterinário Hermeto José Martins de Oliveira (in memorian).

Ao velho e grande amigo, Alessandro da Silva Bonetti, pelo exemplo de bondade e perseverança que ensinou a todos nós (in memorian). 


\section{AGRADECIMENTOS}

Ao Prof. Dr. Flávio Augusto Portela Santos, pelas oportunidades concedidas e conhecimentos transmitidos. Pela confiança, amizade e respeito profissional com que sempre tem tratado seus orientados.

A Fundação de Amparo à Pesquisa do Estado de São Paulo (FAPESP), pela concessão da bolsa de estudos, financiamento do projeto de pesquisa e também, pelo exemplo de profissionalismo e seriedade na administração dos recursos públicos a ela confiados.

Ao Prof. Dr. Wilson Mattos, pela oportunidade de participar do Programa de Apoio ao Ensino (PAE).

Ao Prof. Dr. José Eduardo P. Santos (UCDAVIS-EUA), que apesar da distância, muito contribui para a qualidade final deste trabalho.

Ao Dr. José Manuel Corrêa de Simas, pelo auxílio técnico na execução das análises de sangue.

Ao Prof. Alexandre Vaz Pires, pelo incentivo e auxilio na área veterinária.

Aos demais professores do Departamento de Produção Animal, pela qualidade das disciplinas oferecidas e pela acessibilidade constante.

A todos amigos e colegas de curso, pela companhia agradável e troca de experiências. Em especial a Carla M. Bittar Nussio e Éberson de C. Barnabé, pela amizade e auxílio na condução do experimento de campo e análises laboratoriais. Ao colega, Hugo Imaizumi, pelo auxílio na condução dos experimentos de campo, sem o qual não teria sido possivel a realização dos exames de ultrassonografia.

Aos estagiários Flamarion Barboza (Bizarro) e Marcos de Ben (Simental), pela maneira responsável com que ajudaram na condução do experimento.

Aos funcionários, Carlos César Alves, "Seu" Laureano, Benedito, "Seu" Toneli e "Nequinho", pela companhia agradável, pela maneira responsável e profissional com que desempenham suas respectivas funções.

À Regina M. S: Mirandola, pelo auxílio na condução das análises de sangue, ensinamentos transmitidos e pela extrema boa vontade demonstrada.

Ao Prof. Dr. Paulo Henrique Mazza Rodrigues, pela paciência no auxílio das análises estatísticas.

Aos pós-graduandos André M. da Rocha e Eduardo A. Dias, pela amizade e auxílio na realização das determinações de progesterona.

À Profa. Sílvia Ricci (Dep. de Clínica Médica - HOVET -USP) e ao Prof. Cláudio Alvarenga (Lab. de Dosagens Hormonais - VRA-FMVZ-USP), pela oportunidade de realizar as análises nos respectivos departamentos. 
À Profa. Elizabeth Costa e equipe do NAPGAMA - USP, pela realização dos exames microbiológicos.

Aos Profs. Mário Penz Jr., Sérgio L. Vieira e colegas do Lab. de Ensino Zootécnico (LEZO-UFRGS), pela amizade e ensinamentos transmitidos, os quais foram de grande valia durante o mestrado.

Ao Prof. Dr. Luiz Fernando Laranja, pela amizade e por transmitir aqueles conhecimentos que os livros não ensinam.

A Universidade Federal do Rio Grande do Sul (UFRGS), pela minha formação acadêmica.

À Empresa Elanco Saúde Animal, pela doação das cápsulas de monensina sódica. 


\section{SUMÁRIO}

LISTA DE ABREVIATURAS.................................................................. vii

ÍNDICE DE TABELAS ...........................................................................iii

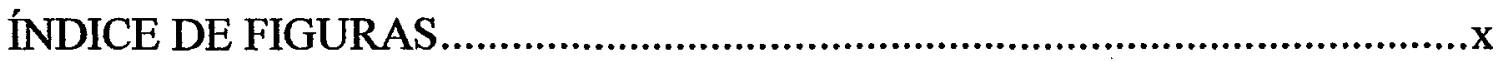

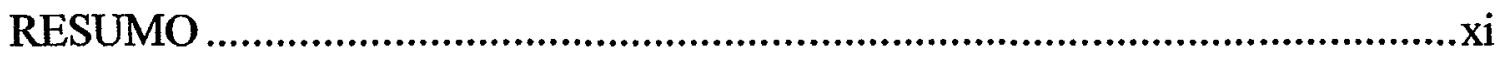

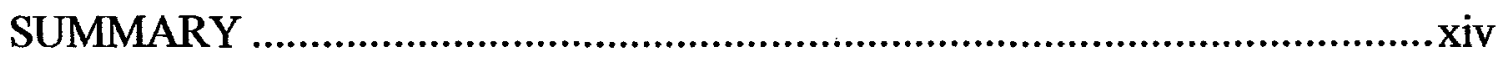

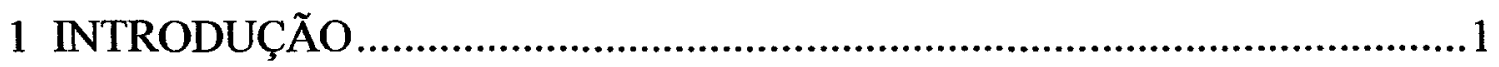

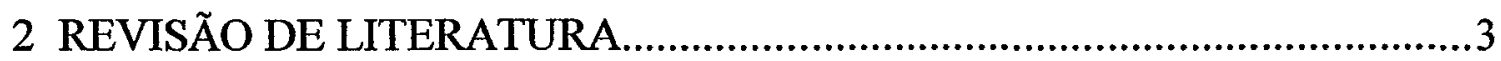

2.1 Período de Transição ....................................................................................

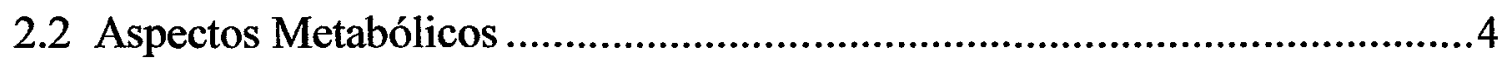

2.3 Aspectos Nutricionais ......................................................................... 8

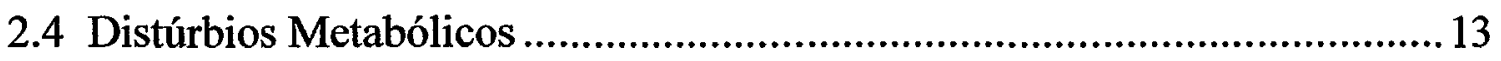

2.5 Utilização de aditivos no período de transição ............................................20

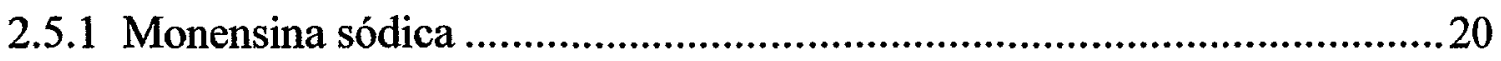

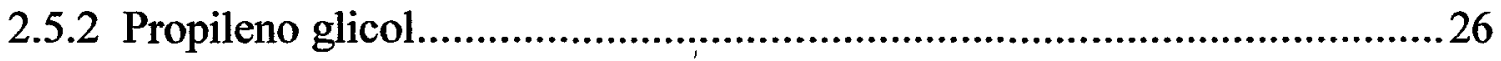

2.6 Balanço energético e desempenho reprodutivo.........................................31

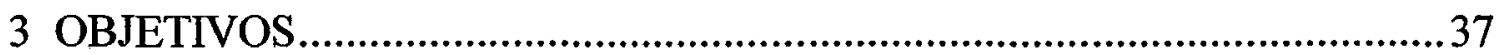

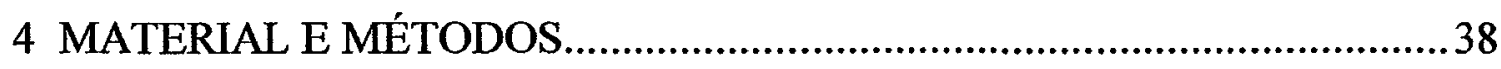

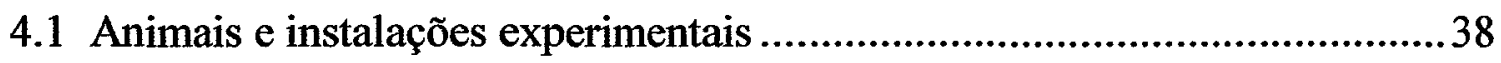

4.2 Tratamentos e delineamento experimental.....................................................38

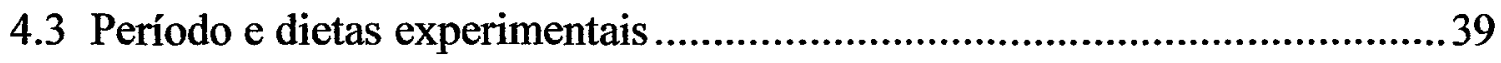

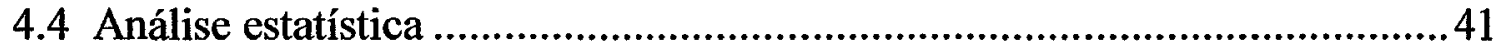

4.5 Procedimentos de coleta e métodos analíticos ...........................................4 
4.5.1 Metodologia de coleta de sangue para as análises de glicose, AGL,

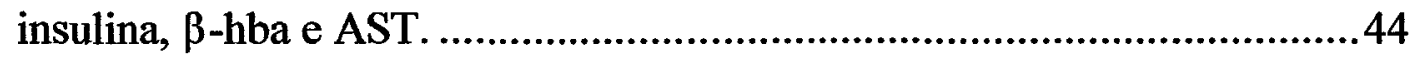

4.5.2 Metodologia para determinação de glicose ................................................45

4.5.3 Metodologia para determinação de insulina ...........................................45

4.5.4 Metodologia para determinação de AGL ..................................................46

4.5.5 Metodologia para determinação de $\beta$-hba.............................................47

4.5.6 Metodologia para determinação de AST.......................................................48

4.5.7 Metodologia de coleta de sangue para determinação de progesterona......49

4.5.8 Metodologia para determinação de progesterona plasmática. ...................49

4.5.9 Metodologia de coleta de dados e cálculo das taxas de incidência de

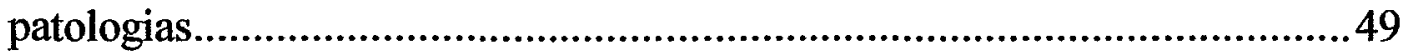

4.5.9.1 Distúrbios Metabólicos ................................................................50

4.5.9.2 Parâmetros reprodutivos....................................................................50

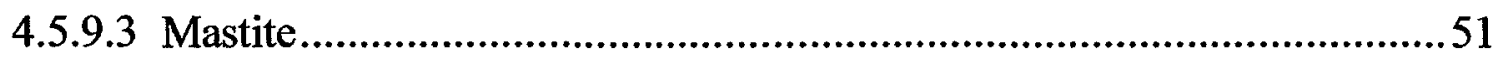

4.5.10 Pesagem e amostragem de leite .........................................................55

4.5.11 Avaliação do escore de condição corporal............................................52

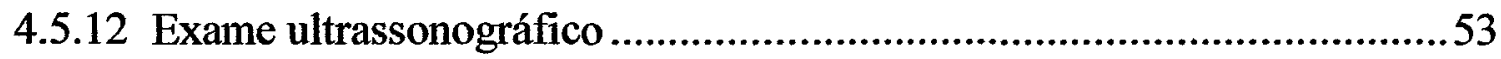

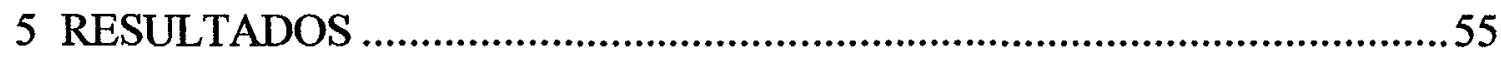

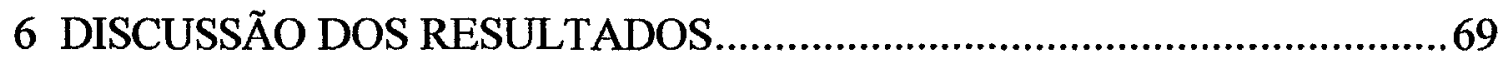

6.1 Produção e composição do leite ....................................................................69

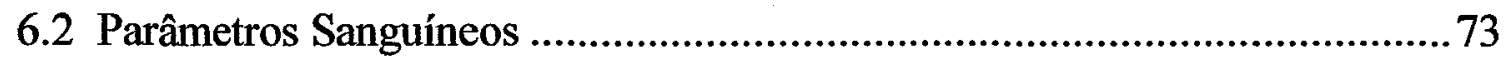

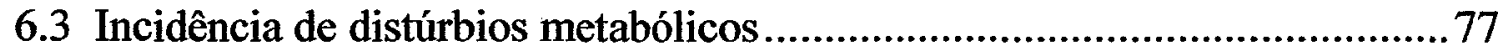

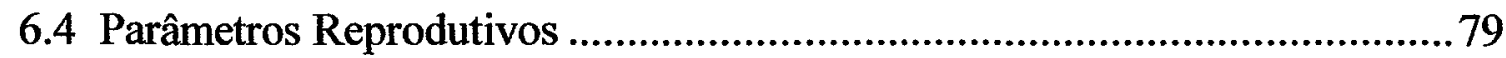

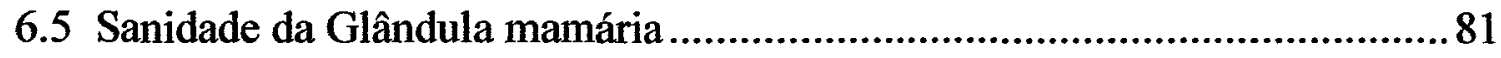

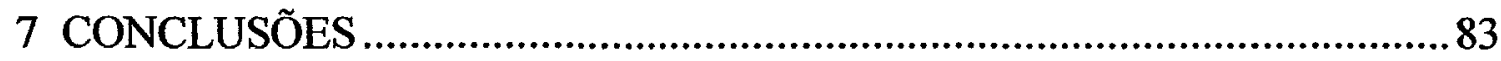

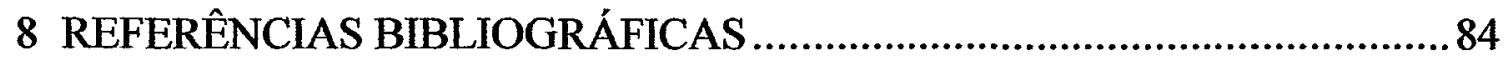




\section{LISTA DE ABREVIATURAS}

\author{
AGL ácidos graxos livres \\ AGV- ácidos graxos voláteis \\ AST aspartato aminotransferase \\ BE balanço energético \\ BEN balanço energético negativo \\ B-HBA $\beta$-hidroxibutirato \\ BST somatotropina bovina \\ C controle \\ CCS contagem de células somáticas \\ CLL cápsula de liberação lenta \\ CNE carboidrato não estrutural \\ ECC escore de condição corporal \\ EE- extrato etéreo \\ $E L_{L}$ - energia líquida de lactação \\ FDA- fibra em detergente ácido \\ FDN- fibra em detergente neutro \\ HC hormônio do crescimento \\ IGF insulin growth factor
}

LCG leite corrigido para gordura

LH hormônio luteinizante

LHRH hormônio liberador de LH

LSH lipase sensivel a hormônio

M monensina sódica

LCE leite corrigido para energia

MM- matéria mineral

MS- matéria seca

NDT- nutrientes digestiveis totais

NRC national research council

PB- proteína bruta

PDR- Proteína degradável no rúmen

PG propileno glicol

PNDR- proteína não degradável no rúmen

PV peso vivo

RP retenção de placenta

TG triglicerídeos

VLDL lipoproteína de muito baixa densidade 


\section{ÍNDICE DE TABELAS}

TABELA 1: Características físico-químicas do Propileno glicol ${ }^{+}$.

TABELA 2: Composição (média \pm EPM) das dietas totais fornecidas nos respectivos períodos.

TABELA 3: Composição das dietas experimentais

TABELA 4: Análise de variância para as variáveis de produção e composição do leite.

TABELA 5: Análise de variância para as variáveis com resposta do tipo tudo ou nada.

TABELA 6: Análise de variância para os parâmetros sanguíneos.

TABELA 7: Produção média de leite ( $\mathrm{kg} / \mathrm{vaca} / \mathrm{dia})$, por semana, para as primeiras nove semanas de lactação.

TABELA 8: Produção, produção corrigida para $3,5 \%$ de gordura (LCG $3,5 \%)$ e composição do leite, média das nove primeiras semanas de lactação

TABELA 9: Dias médios, em relação ao dia do parto, das amostras utilizadas para análise de glicose, insulina, AGL e $\beta$-hba.

TABELA 10: Valores médios utilizados como covariável (-35dias), conforme o parâmetro sanguíneo e o tratamento.

TABELA 11: Concentrações plasmáticas médias para os diferentes parâmetros sanguíneos analisados. 
TABELA 12: Concentrações plasmáticas médias de glicose $(\mathrm{mg} / \mathrm{dl})$ ao longo do período experimental, segundo os dias de coleta.

TABELA 13: Concentrações plasmáticas médias de insulina ( $\mu \mathrm{mol} / \mathrm{ml})$ ao longo do período experimental, segundo os dias de coleta

TABELA 14: Concentrações plasmáticas médias de ácidos graxos livres (AGL) ao longo do período experimental, segundo os dias de coleta.

TABELA 15: Concentrações plasmáticas médias de $\beta$-hidroxibutirato ( $\beta$-hba) ao longo do período experimental, segundo os dias de coleta.

TABELA 16: Incidência de cetose subclínica $(\beta-\mathrm{hba} \geq 10 \mathrm{mg} / \mathrm{dl})$ durante as primeiras 9 semanas de lactação.

TABELA 17: Incidência de retenção de placenta (RP), metrite, anestro, cisto ovariano, corpo lúteo persistente, tempo para involução uterina (Inv $U$ ), dias para primeira ovulação e número de ciclos estrais curtos ao longo das nove primeiras semanas de lactação.

TABELA 19: Incidência de mastite clínica utilizando como unidade experimental a vaca ou um quarto mamário, escore médio de mastite clínica e contagem de células somáticas (CCS) no leite.

TABELA 20: Distribuição dos quartos mamários (\%) por tratamento, segundo o escore de mastite clínica 


\section{ÍNDICE DE FIGURAS}

FIGURA 1: Fórmula estrutural da monensina sódica.

FIGURA 2: Fórmula estrutural do Propileno Glicol (PG).

FIGURA 3: Níveis plasmáticos de AGL (-口-) e $\beta$-hba (- - - - -) ao longo do período experimental para o tratamento controle, monensina sódica e propileno glicol.

FIGURA 4: Variação de $E C^{1}$ ao longo do período experimental para o

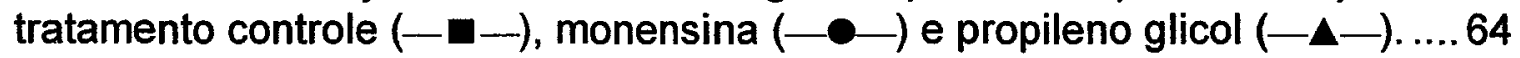




\section{SUPLEMENTAÇÃO DE PROPILENO GLICOL E MONENSINA SÓDICA PARA VACAS LEITEIRAS NO PERIODO DE TRANSIÇÃO}

Autor: Sérgio de Oliveira Juchem Orientador: Prof. Dr. Flávio Augusto Portela Santos

\section{RESUMO}

Foram avaliadas 44 vacas holandesas em um delineamento em blocos casualisados, onde cada bloco foi constituído de três vacas, submetidas a três tratamentos durante o período pré-parto: controle, monensina sódica e propileno glicol.

O período de avaliação estendeu-se do dia da secagem até a nona semana de lactação e as amostras de sangue dos dias $-35,-21,-14,-7,-3$, parto, 7, 14 e 21 foram utilizadas para análise de glicose, insulina, ácidos graxos livres, $\beta$-hidroxibutirato e aspartato aminotransferase. A monensina sódica foi fornecida a partir de 35 dias antes da data prevista para o parto sob a forma de cápsulas de liberação lenta (Rumensin $A B C^{\circledR 1}$ ) e o propileno glicol (300 ml) a partir de 21 dias, sob a forma de "drench". Com o objetivo de comparar o fornecimento destes dois aditivos exclusivamente durante o período pré-parto, as vacas do tratamento controle e propileno glicol também receberam cápsulas de monensina sódica ao parto.

\footnotetext{
${ }^{1}$ Elanco Saúde Animal, Eli Lilly do Brasil Lida.
} 
Não houve diferença $(P=0,72)$ para produção de leite $(31,07 ; 31,57$; $31,18 \mathrm{~kg} / \mathrm{v} / \mathrm{d}$ ), respectivamente para os tratamentos controle $(C)$, monensina sódica (M) e propileno glicol (PG). O tratamento monensina sódica $(31,27$ $\mathrm{kg} / \mathrm{v} / \mathrm{d}$ ) apresentou tendência de maiores produções de leite corrigido para $3,5 \%$ de gordura $(P=0,15)$ quando comparado ao controle $(29,93 \mathrm{~kg} / \mathrm{v} / \mathrm{d})$, porém semelhante ao propileno glicol $(30,36 \mathrm{~kg} / \mathrm{v} / \mathrm{d})$.

$O$ percentual de gordura do leite foi maior $(P=0,056)$ para as vacas que receberam $M(3,46 \%)$ antes do parto quando comparado ao $C(3,27 \%)$, sendo semelhante ao PG $(3,37 \%)$. Resultado semelhante $(P=0,10)$ ocorreu em relação a produção de gordura do leite $(1084 ; 1017$ e $1040 \mathrm{~g} / \mathrm{v} / \mathrm{d})$, respectivamente. Os teores de proteína no leite foram menores $(P=0,0006)$ no tratamento $M(2,92 \%)$ em relação aos demais $(3,02 \%)$, não havendo diferença para produção de proteína do leite. O percentual de lactose foi superior $(P=0,0006)$ para $C(4,7 \%)$ e semelhante entre $M$ e $P G, 4,63$ e $4,60 \%$, respectivamente.

As vacas que receberam $P G$ tiveram maior concentração de glicose e menores concentrações de $\beta$-hidroxibutirato $(P<0,05)$, havendo efeito da interação tempo $x$ tratamento. $O P G$ apresentou maiores $(P=0,007)$ concentrações de insulina e menor $(P=0,034)$ atividade de aspartato aminotransferase que os demais tratamentos. As concentrações de ácidos graxos livres foram menores $(P=0,009)$ para $P G$ quando comparado a $M$, entretanto não diferiram de $C$.

Não houve efeito significativo sobre os parâmetros reprodutivos avaliados e incidência de distúrbios metabólicos, nem tão pouco sobre escore de condição corporal. $O$ tratamento $P G$ apresentou maiores $(P=0,0062)$ concentrações de progesterona plasmática que $\mathrm{C}$ no primeiro ciclo estral, no entanto menor $(P=0,0062)$ que este no segundo, não havendo diferenças em relação a $M$.

$O$ tratamento controle apresentou maior $(P=0,0001)$ contagem de células 
somáticas no leite $\left(602 \times 10^{3}\right.$ células $\left./ \mathrm{ml}\right)$ que os tratamentos $M\left(506 \times 10^{3}\right.$ células $/ \mathrm{ml})$ e PG $\left(335 \times 10^{3}\right.$ células $\left./ \mathrm{ml}\right)$. O escore médio de mastite clínica foi menor $(P=0,047)$ para $P G(1,20)$ que para $M(1,57)$ e $C(1,58)$, como também foi menor $(P=0,042)$ a incidência de quartos mamários afetados clinicamente $(16,66 ; 35$ e $32,08 \%)$, respectivamente, entretanto não diferindo quanto a incidência de vacas com mastite clínica $(P=0,66)$. 


\title{
SUPPLEMENTATION OF PROPYLENE GLYCOL AND SODIUM MONENSIN TO DAIRY COWS IN THE TRANSITION PERIOD
}

\author{
Author: Sérgio de Oliveira Juchem \\ Adviser: Prof. Dr. Flávio Augusto Portela Santos
}

\section{SUMMARY}

Forty-four multiparous Holstein cows were evaluated on a randomized block design, with three cows per block. The objective was to compare the effect of sodium monensin (M) and propylene glycol (PG) during the prepartum period on milk production and composition, incidence of metabolic diseases and reproduction, through the first nine weeks of lactation.

The evaluation period started at drying off and extended up to the ninth week of lactation. Blood samples from days $-35,-21,-14,-7,-3$, parturition, 7 , 14 e 21 were used in analysis. Sodium monensin was administered via a slow releasing capsule (Rumensin $A B C^{\circledR 1}$ ) at 35 days before the expected calving date and propylene glycol $(300 \mathrm{ml})$ through oral drench, starting 21 days before the expected calving date. To ensure that treatments would be restricted to prepartum period, control $(\mathrm{C})$ and propylene glycol cows received a monensin capsule within 24 hours after calving.

There was no difference on milk production $(31,07 ; 31,57 ; 31,18 \mathrm{~kg} / \mathrm{c} / \mathrm{d})$ and milk protein yield, respectively for control, sodium monensin and propylene 
glycol treatments. Sodium monensin group $(31,27 \mathrm{~kg} / \mathrm{d})$ tended $(P=0,15)$ to produce more $3,5 \%$ fat corrected milk compared to control $(29,93 \mathrm{~kg} / \mathrm{d})$, but similar to $P G(30,36 \mathrm{~kg} / \mathrm{c} / \mathrm{d})$. Milk fat content was greater $(P=0,056)$ for cows receiving $M$ before calving $(3,46 \%)$ than for $C$ cows $(3,27 \%)$, but PG cows $(3,37 \%)$ showed no difference from both. The same trend $(P=0,10)$ was observed for milk fat yield (1084; 1017 e $1040 \mathrm{~g} / \mathrm{c} / \mathrm{d})$, respectively. Milk protein content was lower $(P=0,0006)$ for monensin group $(2,92 \%)$ than the other ones $(3,02 \%)$. Control cows $(4,72 \%)$ showed grater $(P=0,0006)$ lactose in milk than $M$ $(4,63 \%)$ or PG $(4,60 \%)$ cows.

PG treated cows had greater blood glucose and lower $\beta$-hidroxybutyrate $(P<0,05)$, greater blood insulin $(P=0,007)$ and lower $(P<0,034)$ aspartate aminotransferase activity than the other groups. Blood free fatty acids were lower $(P=0,009)$ for $P G$ than $M$ treated cows, but similar to $C$ cows.

There was no effect on reproduction and incidence of metabolic diseases, neither in body condition score. Blood progesterone was greater $(P=0,0062)$ for $P G$ than $C$ cows in the first estrus cycle, but lower in the second.

Somatic cell count was greater $(P=0,0001)$ for $C$ cows $\left(602 \times 10^{3}\right.$ cells $\left./ \mathrm{ml}\right)$ than $M\left(506 \times 10^{3}\right.$ cells $\left./ \mathrm{ml}\right)$ and $P G$ cows $\left(335 \times 10^{3}\right.$ cells $\left./ \mathrm{ml}\right)$. The average clinical mastitis score, per quarter, was lower $(P=0,047)$ for $P G(1,20)$ treated cows than $M$ and $C$ cows $(1,57$ and 1,58$)$, respectively. There were less $(P=0,042)$ clinical affected quarters in $P G$ treated cows than in $M$ and $C$ cows $(16,66 ; 35,00$ and $32,08 \%)$, respectively. 


\section{INTRODUÇÃO}

Alguns autores (Drackley, 1998b; Mallard et al., 1998; Goff \& Horst, 1997b; Bell,1995; Grummer, 1995) têm abordado a importância da relação entre nutrição, ambiente, reprodução e saúde animal, no entanto, devido à complexidade do tema, a obtenção de recomendações técnicas precisas é um processo demorado, embora algumas diretrizes básicas já estejam disponíveis.

Um dos principais objetivos do manejo de vacas durante o período préparto é minimizar o processo de mobilização de gordura corpórea e assim, reduzir os efeitos negativos que este evento possa causar sobre o desempenho da vaca leiteira (Grummer, 1995).

A maximização do consumo de matéria seca constitui-se em ferramenta importante no controle da mobilização de gordura em vacas em transição, entretanto, não é suficiente para solucionar o problema completamente. A utilização de aditivos gliconeogênicos como a monensina sódica e o propileno glicol vem sendo estudada com o objetivo de minimizar estes efeitos, característicos desta fase (Laranja da Fonseca et al., 1998; Duffield et al., 1999).

Segundo Drackley (1998b), o correto manejo da vaca leiteira durante o periodo pré-parto é fundamental para a eficiência econômica de uma propriedade leiteira, já que problemas durante esta fase podem resultar em aumento nos custos com veterinário e medicamentos. Associado a isto, problemas metabólicos durante 0 início de lactação podem diminuir 0 desempenho reprodutivo e provocar perdas na produção de leite, da ordem de 
900 a $1800 \mathrm{~kg}$ de leite por lactação.

Mallard et al. (1998) em recente revisão abordaram a característica imunodepressiva em vacas no período de transição, destacando mais especificamente, os efeitos negativos sobre a sanidade da glândula mamária. Segundo Goff \& Horst (1997b) "a incidência de distúrbios metabólicos e infecciosos é aumentada quando uma ou mais funções fisiológicas estão comprometidas".

O manejo de vacas durante o final de gestação e início de lactação representa uma importante área de atuação para produtores e técnicos, a fim de viabilizar economicamente uma propriedade leiteira e, ao mesmo tempo, produzir um produto de melhor qualidade, seja pela menor contagem de células somáticas, ou pela ausência de resíduos medicamentosos indesejados no leite. 


\section{REVISÃO DE LITERATURA}

\subsection{Período de Transição}

Este é um periodo caracterizado por suas particularidades no que se refere à exigência nutricional, consumo de alimento, padrões hormonais e metabólicos. As alteraçōes que ocorrem durante o final da gestação e início de lactação caracterizam muito bem o termo homeorrese, definido por Bauman \& Currie (1980) como "as alterações coordenadas ou orquestradas no metabolismo tecidual, necessárias para atender a um estágio fisiológico predominante". E este é realmente o caso de vacas em final de gestação e início de lactação, as quais dependem de alternativas fisiológicas que permitam o atendimento das altas exigências, em glicose principalmente, do feto e da glândula mamária, sem no entanto, comprometer a saúde geral do animal.

Grummer (1995) definiu o período de transição como a fase compreendida entre as três semanas que antecedem ao parto e as três primeiras semanas de lactação, salientando as alterações no metabolismo, implícitas no processo de adaptação do organismo animal para uma situação adversa, o início de lactação.

Os cuidados na alimentação de vacas durante esta fase são de extrema importância, pois têm implicações sobre o desempenho produtivo, sobre a incidência de distúrbios metabólicos, desempenho reprodutivo, eficiência do sistema imunológico e saúde geral do animal (Drackley, 1998a, 1998b; Mallard 
et al., 1998; Goff \& Horst, 1997b; Bell,1995; Grummer, 1995; Holtenius, 1993; Bauman \& Currie, 1980). Estes fatores por fim têm impacto direto ou indireto na rentabilidade econômica de um sistema de produção de leite (Drackley, 1998b).

\subsection{Aspectos Metabólicos}

O período final da gestação traz consigo modificações no metabolismo e na dinâmica hormonal, conseqüência de um controle homeorrético que possibilita ao organismo coordenar a partição de nutrientes entre os diferentes órgãos e tecidos, favorecendo neste caso, o útero e a glândula mamária.

Compilando dados de diferentes autores, Bell (1995) concluiu que a oxidação fetal de glicose e lactato seriam suficientes para atender 50 a $60 \%$ do seu gasto energético, 10 a $15 \%$ seriam provenientes do acetato e os restantes 30 a $40 \%$, seriam, em grande parte, decorrentes da oxidação de aminoácidos. A quantidade depositada como proteína fetal representa em torno de $50 \%$ do total de aminoácidos extraídos pelo feto de vacas, sugerindo que parte destes aminoácidos seja utilizada com outro propósito, que não exclusivamente deposição tecidual (Reynolds et. al., 1986). Durante o final de gestação, o útero pode extrair da circulação materna até $72 \%$ do total de aminoácidos circulantes (Sniffen et al., 1992).

O transporte transplacentário de corpos cetônicos, ácidos graxos de cadeia curta e longa é bastante restrito em ruminantes (Bell, 1993), o que justifica a grande demanda por glicose e aminoácidos. O requerimento energético fetal para síntese de gordura no final da gestação é bastante baixo, representando ao redor de $5 \%$ do requerimento total (Bell, 1992). Embora os tecidos placentários e uterinos representem apenas $20 \%$ do peso de um útero grávido, estes tecidos consomem pelo menos $58 \%$ da glicose retirada da circulação materna (Reynolds et al., 1986), sendo 60 a $70 \%$ oxidada completamente e o restante parcialmente a lactato, o qual é liberado 
novamente na circulação materna. Fica claro então, que além do maior aporte de nutrientes exigidos, o útero grávido exerce um poder seletivo, apresentando altas exigências em nutrientes nobres, também essenciais para a vaca prenhe, fundamentalmente glicose e aminoácidos.

No intuito de aumentar a disponibilidade destes nutrientes ao útero e feto, o organismo lança mão de algumas alternativas. Nas últimas semanas antes do parto a vaca já mostra sinais de mobilização de gordura corpórea, caracterizada por aumento nos niveis sanguineos de ácidos graxos livres (AGL) e mobilização de glicogênio hepático (Grummer, 1995). Segundo Bell (1995), "a massiva mobilização de AGL do tecido adiposo durante e após o parto é a marca registrada do período de transição, entre final de gestação e inicio de lactação".

Os AGL são a principal fonte de energia durante o final de gestação e início de lactação (Drackley, 1998a), atuando como um mecanismo de economia de glicose, ou seja, os tecidos periféricos utilizam-nos preferencialmente à glicose e aos aminoácidos. Os niveis de AGL no plasma seguem um padrão crescente a partir da terceira semana pré-parto, apresentando um pico próximo ao parto e decrescendo ao longo da lactação.

Esta dinâmica na concentração plasmática tem sido observada em diferentes avaliações (Tesfa et al., 1999; Vazquez-Anon et al., 1994; Bertics et al., 1992; Skaar et al., 1989), no entanto a sua magnitude varia entre os trabalhos, uma vez que sofre influência de diversos fatores, como horário da coleta de sangue em relação ao fornecimento do alimento (Christensen et al., 1997; Borrebaek et al., 1990), estresse calórico (Collier et al., 1982), composição da dieta (Minor et al., 1998), condição corporal (Reid et al., 1986) e quaisquer outros fatores que possam influenciar o consumo voluntário. Por outro lado, as concentrações séricas de insulina seguem um padrão inverso, diminuindo consideravelmente a medida que o parto se aproxima (Moorby et al., 2000; Studer et al., 1993), estando em parte envolvida no processo de 
aumento de AGL (Petterson et al., 1994; Holtenius, 1993).

Com a proximidade do parto, outros hormônios também têm suas concentrações alteradas. Nos últimos dias de gestação há uma queda nas concentrações plasmáticas de progesterona e aumento nas de estrógeno e cortisol, este último mais proeminente ao redor do parto (Tucker, 1985). As concentrações de hormônio do crescimento $(\mathrm{HC})$ aumentam na última semana de gestação com um pico característico ao parto e a partir de então decrescem gradualmente, apresentando concentrações relativamente altas durante o início de lactação (Moorby et al., 2000; Bauman, 1999; Bell \& Bauman, 1996; Burton et al., 1994; Tucker, 1985).

Jaster \& Wegner (1981), citados por Santos, J. (1996), observaram aumento no número de receptores $\beta$-adrenérgicos nos adipócitos durante esta fase, enquanto McNamara (1988) detectou maior susceptibilidade do tecido adiposo à lipólise, devido a maior responsividade aos hormônios lipolíticos, epinefrina e noraepinefrina. Vazquez-Anon et al. (1996) observaram também menor resposta ao efeito lipogênico da insulina, assim como Petterson et al. (1994). Jaster \& Wegner (1981) sugeriram que o aumento de receptores poderia ser mediado pelo aumento nos niveis circulantes de hormônio do crescimento, já que este aumenta a atividade da enzima lípase sensivel a hormônio (LSH), estimulando o processo de lipólise durante períodos de balanço energético negativo (Lanna, et al., 1995). As baixas taxas de lipogênese próximas ao parto são provavelmente, conseqüência da ação antagônica à insulina exercida pelas altas concentrações de $\mathrm{HC}$ e às baixas concentrações daquele hormônio (Hart et al., 1978). A administração exógena de somatotropina produz efeitos semelhantes aos observados em vacas no período periparto, sugerindo o seu envolvimento chave na partição de nutrientes (Bell \& Bauman, 1996).

A queda no consumo nas semanas que antecedem ao parto, mais intensamente na última semana, intensifica o grau de lipólise, porém este não é 
o único fator responsável (Grummer, 1995). Bertics et al. (1992) observaram que quando não permitiram a redução de consumo pré-parto através do fornecimento das sobras via fístula ruminal, estas vacas apresentaram concentrações de AGL semelhantes aos animais que tiveram depressão de consumo, porém foi observado menor concentração de triglicerídeos (TG) no fígado, comparativamente. Os altos níveis de estrógeno no final da gestação têm sido relacionados como um dos fatores envolvidos na diminuição do consumo voluntário (Forbes, 1995; Grummer, 1993).

Nos últimos dias de gestação, às exigências para crescimento fetal são acrescidas as exigências para sintese de colostro (Grummer, 1995), a qual é considerada um processo de duas fases. A primeira fase envolve diferenciação celular, pouca síntese e secreção de leite semanas antes do parto, enquanto que a segunda fase envolve a síntese do colostro propriamente dito, iniciando alguns dias antes do parto (Bell, 1995). Davis et al. (1979) avaliaram o fluxo sanguíneo, exigência de glicose e acetato pela glândula mamária de cabras no final de gestação e início de lactação. A demanda por glicose um dia após o parto foi nove vezes superior ao medido sete dias antes e cinco vezes ao medido dois dias antes do parto.

Estes dados ilustram bem o crescimento na demanda de glicose pela glândula mamária a medida que se aproxima o parto e inicia a sintese de colostro, como também o drástico aumento nas exigências tão logo se inicia a lactação. As concentrações de HC continuam elevadas durante 0 inicio de lactação e as concentrações de insulina aumentam ao longo deste periodo. A predominância do catabolismo em relação ao anabolismo persiste até o pico de lactação (McNamara, 1991).

Komaragiri \& Erdman (1997) observaram mobilização média de $54 \mathrm{~kg}$ de gordura e $21 \mathrm{~kg}$ proteína em vacas holandesas, de 2 semanas antes do parto até a quinta semana de lactação. Segundo Moe (1965), citado por Drackley (1998b), a energia proveniente da mobilização de lipídios pode representar até 
$33 \%$ da energia utilizada para síntese do leite.

A gliconeogênese hepática está aumentada em função do maior nivel de corticosteróides próximo ao parto (Bell, 1995), evidenciado por glicemias mais elevadas neste período (Vazquez-Anon et al., 1994; Studer et al., 1993). Os níveis de corticosteróides têm sua influência mais restrita ao parto, porém outros autores têm relatado aumentos na gliconeogênese hepática no início de lactação como um todo (Ingvartsen \& Andersen, 2000). Parte é devido ao aumento no aporte de substratos, propionato e aminoácidos, conseqüentes ao maior consumo, maior teor de CNE e proteína da dieta. As alterações hormonais, sobretudo referentes aos niveis de HC circulantes nesta fase, podem também estar envolvidas (Bauman, 1999). Knapp et al. (1992) observaram aumento na gliconeogênese quando incubaram tecido hepático in vitro, coletado de vacas que receberam $\mathrm{HC}$ exógeno, comparativamente a vacas que receberam placebo.

A presente situação de favorecimento do útero grávido e da glândula mamária em relação à vaca é uma situação de risco, onde falhas em algum destes mecanismos de controle podem resultar em efeitos negativos sobre a saúde e o desempenho animal.

\subsection{Aspectos Nutricionais}

Originalmente, produtores, técnicos e pesquisadores mantiveram seu foco principal no manejo e nutrição de vacas lactantes (Grummer, 1995), visto serem, aparentemente, as principais responsáveis pelo retorno financeiro de uma propriedade leiteira. Talvez o conhecimento mais antigo sobre a relação entre nutrição pré-parto e desempenho lactacional seja referente a homeostase do cálcio e incidência de febre do leite (Horst et al., 1997), no entanto, outros aspectos foram pouco estudados até então.

$\mathrm{Na}$ década de 90 , o interesse pelo período que antecede ao parto 
ganhou atenção especial dos pesquisadores e atualmente dispomos de um grande volume de informações na literatura científica sobre o assunto. Alguns trabalhos mais antigos (Curtis et al., 1985) já apontavam uma possivel relação entre a nutrição durante o período pré-parto e a ocorrência de distúrbios metabólicos e reprodutivos, o que despertou 0 interesse de alguns pesquisadores, como Ric Grummer (Wisconsin, EUA), Paul Holtenius (Uppsala, Suécia), Gabriela Varga (Pennsylvania, EUA), entre outros.

O Conselho Nacional de Pesquisa Americano, NRC, é certamente a referência, em exigência nutricional de gado leiteiro, mais utilizada nos Estados Unidos e em muitos outros paises, como é o caso do Brasil. A última edição data de 1989 e, nos últimos 5 anos, tem sido freqüentemente questionada e criticada por diversos autores, os quais propõe um aumento nos niveis de energia (Varga \& Vallimont, 2000; Drackley, 1998a e 1998b; Grummer, 1995 e 1998; Van Saun \& Sniffen 1996; Hutjens, 1996) e proteína (Van Saun \& Sniffen 1996; Hutjens, 1996; Grummer, 1995) nas dietas de vacas nas 3 a 4 últimas semanas de gestação. As recomendações do NRC (1989) prevêem, para determinado peso vivo, uma exigência energética e protéica constantes durante todo o período seco, assim como assumem um crescimento fetal e consumo de alimento constantes durante esta fase.

A depressão no consumo de alimento nas últimas semanas antes do parto é um dos acontecimentos mais característicos dentre as inúmeras alterações a que o organismo animal é submetido durante esta fase. Ela é mais intensa durante a última semana pré-parto, podendo reduzir o consumo em $30 \%$ ou mais do observado aos 21 dias antes do parto(Santos, J., 1996; Vazquez-Anon et al., 1994; Van Saun et al., 1993; Bertics et. al., 1992).

Analisando os dados de 300 animais de 8 estudos diferentes, Grummer (1998) estimou o consumo de novilhas e vacas durante o período pré-parto. As novilhas ( $n=141)$ consumiram $1,77 \%$ do peso vivo (PV) $(10,6 \mathrm{~kg} \mathrm{MS})$ aos 21 dias e as vacas ( $n=158), 1,99 \%$ PV (14,6 $\mathrm{kg} \mathrm{MS})$. Um dia antes do parto, os 
consumos reduziram para 1,29\% PV (7,7 kg MS) e 1,37\% PV (10,0 kg MS) para novilhas e vacas, respectivamente. A redução de consumo foi ligeiramente superior em vacas $(31,3 \%)$ que em novilhas $(27,2 \%)$, bem semelhante ao observado por Bertics et al. (1992).

Bell et al. (1995) abateram 18 vacas holandesas multíparas gestantes entre os dias 190 e 270 de gestação. Estes autores observaram que a taxa de acréscimo de energia ao útero grávido aumentou de $567 \mathrm{kcal} / \mathrm{dia}$ aos 190 dias para $821 \mathrm{kcal} / \mathrm{dia}$ aos 270 dias de gestação. A mesma tendência foi observada para $\mathrm{PB}$, de $62 \mathrm{~g} / \mathrm{dia}$ para $117 \mathrm{~g} / \mathrm{dia}$, ou seja, um aumento aproximado de $88 \%$ para proteína e $44 \%$ para energia. Portanto, Grummer $(1995 ; 1998)$ e outros autores (Van Saun \& Sniffen, 1996; Hutjens, 1996) participam da opinião que as recomendações do NRC (1989) subestimam as exigências energéticas de uma vaca no terço final de gestação.

Dirksen et al. (1985) observaram que o aumento no nível de concentrado na dieta estimulava o crescimento das papilas ruminais, de $0,3 \mathrm{~mm}^{2}$ para 1,2 $\mathrm{mm}^{2}$ de área, necessitando de 4 a 6 semanas para completa adaptação. A superfície das papilas ruminais está diretamente relacionada à capacidade de absorção de ácidos graxos voláteis (AGV), evitando o acúmulo excessivo de ácidos no rúmen, que pode predispor o animal à acidose ruminal (Van Soest, 1994). Portanto, vacas no período pré-parto deveriam receber dietas mais ricas em carboidratos não estruturais (CNE) em torno de 4 semanas antes do parto, a fim de iniciar a adaptação da mucosa para a próxima fase (Santos, J. \& Santos, F., 1998; Hutjens, 1996). O incremento nos teores de CNE em dietas pré-parto, seja pela inclusão de concentrado ou aumento na participação de silagem de milho na fração volumoso, irá aumentar o teor energético da dieta assim como promover a adaptação da mucosa ruminal (Bell, 1992).

Vandehaar et al. (1999) avaliaram 4 niveis energéticos e protéicos durante o período pré-parto, variando de 1,30 a 1,61 Mcal/kg de $E L_{L}$ e de 12,2 a $16,2 \%$ de PB. As vacas do tratamento alta energia, quando comparadas ao 
controle (1,30 Mcal/kg), ganharam mais condição corporal, apresentaram níveis de AGL sanguíneo inferiores durante o período pré-parto e menor concentração de triglicerídeo (TG) hepático ao parto, não sendo observado efeito em produção de leite pós-parto. Não houve benefício em suplementar proteina acima dos níveis recomendados pelo NRC (1989). Tesfa et al. (1999) avaliaram três níveis energéticos $(0,75 ; 1,0$ e 1,25 da exigência em energia metabolizável, segundo ARC) e suplementação com dois níveis de farelo de canola $(0,3$ ou $1,5 \mathrm{~kg} / \mathrm{vaca} / \mathrm{dia})$ durante 0 periodo pré-parto, em um delineamento fatorial. As vacas do tratamento alta energia tiveram um consumo médio pré-parto de 29,38 Mcal EM/dia e apresentaram produção inferior aos demais tratamentos durante os 60 dias de lactação, porém significativo apenas na sexta e sétima semana. Minor et al. (1998) forneceram dois niveis energéticos durante o pré-parto (1,34 e 1,63 Mcal EL $L_{L} / \mathrm{kgMS} ; 23,5$ e 43,8\% de CNE) mantendo as diferenças em CNE (41,7 e 46,5\%) durante a lactação, porém com densidades energéticas semelhantes (1,70 e 1,74 Mcal EL $/ \mathrm{kgMS}$ ). As vacas que receberam o tratamento com alto teor de CNE apresentaram maior consumo pré-parto (1,9 vs $1,5 \%$ PV), menor concentração plasmática de AGL, $\beta$-hba e menor teor de TG hepático aos 28 dias de lactação.

Durante os primeiros 25 a 50 dias de lactação, a vaca encontra-se em balanço energético e protéico negativos. Durante esta fase é indispensável a utilização de reservas corporais para manutenção da produção de leite até que as exigências sejam completamente atendidas através do consumo de alimento (Komaragiri \& Erdman, 1997; Putnam \& Varga, 1997).

Na última edição do NRC, de 1989, a exigência protéica sugerida para vacas leiteiras no período seco (682 $\mathrm{kg}$ de peso vivo) é de $12 \%$ de PB, baseando-se em um consumo de $11,075 \mathrm{~kg}$ de MS/dia, portanto equivalente a $1329 \mathrm{~g}$ de proteína/dia, não havendo nenhuma recomendação quanto aos niveis de PNDR. Alguns autores (Grummer, 1995; Hutjens, 1996; Van Saun \& Sniffen, 1996) têm sugerido que estas recomendações estariam aquém do 
necessário, podendo desta forma expor os animais a um balanço protéico negativo durante a última semana de gestação. As observações destes autores encontram respaldo em levantamentos como o feito por Curtis et al. (1985), avaliando 31 fazendas e 1374 vacas, que observaram menor risco de ocorrência de retenção de placenta e casos clínicos de cetose primária, quando o nível protéico da dieta, nas últimas 3 semanas de gestação, foi superior aos requerimentos estabelecidos pelo NRC (1989).

Vandehaar et al. (1999) não encontraram nenhum efeito, produtivo ou metabólico, quando forneceram diferentes niveis de proteína $(12,2$ a 16,2\% PB) a partir dos 25 dias antes do parto, porém as dietas apresentavam níveis crescentes de energia, tornando confusa a interpretação dos resultados. Mais recentemente, outros trabalhos (Varga et al. 2000; Grummer 1998; Putnam \& Varga, 1997) têm sugerido que as recomendações protéicas do NRC (1989) seriam suficientes para atender às exigências de vacas nas últimas semanas de gestação, podendo inclusive estar em excesso em alguns casos (Putnam \& Varga, 1997). Possivelmente, vacas primiparas pudessem estar expostas a um balanço protéico negativo nos últimos três dias antes do parto (Grummer, 1998). O fornecimento de maiores níveis de PB $(12,4$ e $15,3 \%)$ para novilhas prenhes, provenientes da inclusão de farinha de sangue, aumentou o teor de proteína do leite e diminui $(P<0,10)$ o número de inseminações por prenhes (Van Saun, 1993). Santos, J. et al. (1999) observaram benefício da suplementação protéica pré-parto acima das recomendações do NRC (1989) (14 vs $12 \%$ PB) apenas para novilhas, mas não para vacas.

Putnam \& Varga (1998) observaram um aumento na retenção de proteína em vacas no final de gestação a medida que aumentaram o nível protéico da dieta (1172; 1331 e $1582 \mathrm{~g}$ de proteína/vaca/dia), no entanto não houve diferença em produção de leite e todos os animais apresentaram balanço protéico positivo durante a avaliação. Os níveis plasmáticos de glicose aumentaram linearmente a medida que aumentou a PB da dieta, não havendo 
diferença para AGL e insulina. Putnam et al. (1999) avaliaram dois niveis protéicos (13,3 e 17,8\% PB) e administração de somatotropina bovina (BST) a partir dos 28 dias pré-parto até os 42 dias de lactação. A utilização de BST diminui os niveis plasmáticos de AGL e $\beta$-hba, aumentou os níveis de glicose e produção de leite, porém não houve efeito do fornecimento de maiores níveis de proteína.

As respostas ao aumento do nível de energia nas 3 semanas pré-parto, sobretudo proveniente de CNE, têm mostrado resultados mais coerentes entre os trabalhos, sobretudo no que se refere a parâmetros metabólicos. Os resultados inconsistentes relativos a utilização de maiores niveis de PB no préparto ou de maior teor de PNDR suportam, até o momento, as recomendações tradicionais, no entanto o estudo mais aprofundado sobre as exigências em aminoácidos de vacas no período de transição pode fornecer maiores esclarecimentos sobre o assunto (Putnam \& Varga, 2000; Grummer, 1998).

Em trabalho recente (Xu et al., 1998) foi observado que o ajuste das dietas em proteína metabolizável, lisina e metionina para vacas no período de transição aumentou significativamente o desempenho lactacional, constituindose um campo ainda pouco explorado na área de nutrição.

\subsection{Distúrbios Metabólicos}

A maior parte dos distúrbios metabólicos como hipocalcemia, cetose, esteatose hepática e deslocamento de abomaso ocorrem durante as duas primeiras semanas de lactação (Goff \& Horst, 1997b). O início de lactação expõe a vaca leiteira a uma drástica modificação no seu metabolismo, parte já iniciada durante o período pré-parto. A fim de atender as exigências para produção de leite em um momento onde o consumo de alimento não é capaz de atendê-las em plenitude, o animal faz uso de suas reservas corporais (Butler, 2000; Komaragiri \& Erdman, 1997; Santos, J., 1996), porém este 
artifício é de resultado limitado. A falta de sincronia entre os AGL mobilizados e o fornecimento de glicose e seus precursores através do trato digestivo é o ponto chave na ocorrência de alterações patológicas do metabolismo energético, possibilitando a ocorrência de cetose, esteatose hepática e outras patologias secundárias.

A retirada dos $A G L$ da circulação sanguínea pelo figado está diretamente relacionada a sua concentração na corrente sanguínea (Bauchart, 1993; Grummer 1993; Lean et al., 1992). Uma vez absorvidos pelo fígado, podem ter três destinos básicos diferentes: oxidação completa, incompleta ou síntese de triglicerídeos.

A oxidação completa dos AGL produz energia em forma de ATP e $\mathrm{CO}_{2}$ via Ciclo de Krebs e cadeia respiratória, exigindo para isto a disponibilidade de oxalacetato, para que a Acetil CoA possa ser oxidada. A oxidação incompleta da Acetil CoA produz como produto final os corpos cetônicos, acetoacetato e $\beta$-hidroxibutirato (Lean et al., 1992; Reynolds et al., 1988).

O butirato absorvido no rúmen é, total ou parcialmente, oxidado pelo epitélio ruminal a $\mathrm{CO}_{2}$ e $\beta$-hba, podendo também servir de precursor para síntese de $\beta$-hba no fígado, quando for o caso. Aproximadamente $50 \%$ ou mais do butirato ruminal é metabolizado a $\beta$-hba pelas células epiteliais do rúmen (Hird \& Symons, 1961), citados por Lean et al. (1992). Portanto, figado e epitélio ruminal são as fontes mais importantes de cetogênese nos ruminantes. $\mathrm{Em}$ animais alimentados, em condições de balanço energético positivo, o principal substrato para cetogênese hepática é o butirato. Em períodos de alta demanda energética e balanço negativo de energia, caracterizado por aumento na mobilização de reserva corpórea e conseqüente aumento de $A G L$ sanguíneo, estes ácidos graxos tornam-se os precursores cetogênicos mais importantes (Zammit, 1990).

Propionato e aminoácidos são os principais precursores de glicose nos ruminantes, embora lactato e glicerol também sejam utilizados (Reynolds et al., 
1994). O reduzido consumo de alimento no início de lactação fornece quantidades insuficientes de aminoácidos e de propionato que devem atender, primariamente, as exigências de glicose da glândula mamária, portanto criando uma situação crônica de baixa disponibilidade de oxalacetato e seus precursores.

A $\beta$-oxidação dos ácidos graxos de cadeia longa, entre eles os $A G L$, ocorre no interior da mitocôndria e sua entrada é mediada pelos transportadores carnitina palmitoiltransferase I (CAT I) e II (CAT II). Uma vez no interior da mitocôndria, a $\beta$-oxidação produz Acetil-CoA e NADH. $O$ aumento de Acetil-CoA proveniente da oxidação dos ácidos graxos e a baixa disponibilidade de oxalacetato durante 0 início de lactação, favorecem o direcionamento no sentido da formação de acetoacetil-CoA e posteriormente, acetoacetato e $\beta$-hba (Drackley, 1999; Lean et al., 1992).

Brindle et al. (1985), citado por Drackley (1999), observaram efeito inibitório de malonil-CoA sobre CAT I e efeito semelhante foi produzido por metilmalonil-CoA, intermediário na gliconeogênese a partir de propionato (Drackley, 1999). Portanto, o propionato pode ter ação inibitória sobre cetogênese hepática, a partir do aumento de metilmalonil-CoA, do aumento intra mitocondrial de oxalacetato e aumento de insulina (Lean et al., 1992).

O aumento excessivo de corpos cetônicos no sangue é denominado de cetose, podendo apresentar-se sob a forma clinica ou subclínica (Lean et al., 1991). A cetose tem sido relacionada com perdas em produção de leite e predisposição à ocorrência de outras patologias, como metrite e mastite. Os sintomas clínicos são caracterizados por anofagia (redução no consumo de alimento), temperatura corpórea normal, hálito cetótico característico e, em quadros mais avançados, sintomas nervosos, coma e morte (Guard, 1995). A forma subclínica é diagnosticada em função das concentrações sanguíneas de $\beta$-hba, considerado pela maioria dos autores (Green et al., 1999; Santos, M., 1998; Lago, 1997; Santos, J., 1996), positivo para concentraçōes acima de 10 
$\mathrm{mg} / \mathrm{dl}$, embora outros valores também tenham sido utilizados (Duffield et al., 1998b; Emery et al. 1964).

Os dados sobre incidência de cetose clínica e subclínica no Brasil são restritos. Lago (1997) encontrou uma incidência de $13,56 \%$ de cetose subclínica e $0,84 \%$ ( 1 vaca) de cetose clínica. Magalhães e Belém (1995) relataram uma incidência de $18,18 \%$ de casos subclínicos, enquanto que Castillo et al. (1994) não observaram nenhum caso, segundo informações reportadas por Lago (1997).

Jordan \& Fourdraine (1993) analisaram, através de um questionário, os dados dos 61 melhores produtores americanos, com média de produção de leite de $11.359,9 \mathrm{~kg} / \mathrm{vaca} / 305$ dias de lactação. A incidência média de cetose clínica foi de $3,7 \%$, porém variou de 0 a $20 \%$, o mesmo se repetiu para outras patologias, $7,2 \%$ de febre do leite ( 0 a $44,1 \%$ ) e $3,3 \%$ de deslocamento de abomaso (0 a 14\%). Os dados de Santos, M. (1998), obtidos em rebanhos do Estado de São Paulo, também mostraram um alto efeito de rebanho sobre as concentrações médias de $\beta$-hba. Portanto, em rebanhos de alto potencial produtivo, onde a incidência de cetose poderia ser mais alta, os valores médios foram semelhantes ao reportado em rebanhos com produção inferior (Olsson, 1993). A variação nos índices observados indica que diferenças de manejo e nutrição, dentro de cada propriedade, influenciaram positiva ou negativamente estes índices.

Detilleux et al. (1994) avaliaram o efeito da ocorrência de cetose clínica sobre a produção de leite até 17 dias após o diagnóstico, em 60.851 vacas Ayrshires em propriedades leiteiras na Finlândia. Estes autores encontraram quedas na produção de leite de 33,9 a $52,6 \mathrm{~kg}$ durante este período, ou seja, 2 a $3 \mathrm{~kg}$ de leite/vaca/dia. As perdas foram menores em vacas de primeira e segunda cria, no entanto, quando analisaram a produção da lactação inteira (305 dias), as vacas que apresentaram quadro clínico de cetose tiveram uma produção de leite superior, produzindo $141,1 \mathrm{~kg}$ a mais, sugerindo uma maior 
predisposição a este tipo de distúrbio de vacas com potencial produtivo mais elevado (Ostergaard \& Sorensen, 1998).

Gröhn (1996) analisou os dados de 8.070 vacas holandesas do estado de Nova York com o intuito de avaliar a relação entre potencial produtivo e a ocorrência de cetose, deslocamento de abomaso e outras cinco patologias. Não encontrou efeito significativo entre produção de leite e as duas patologias citadas, ao contrário do publicado por Olsson (1993), que observou $2 \%$ de incidência de cetose clínica para vacas produzindo entre 4.000 e $5.500 \mathrm{~kg}$ LCE (leite corrigido para energia) e 3,3\% para o nível de produção de 7.500 a 8.500 kg de LCE . Apesar de não encontrar relação com produção de leite, Gröhn (1996) observou que a possibilidade de ocorrência de cetose aumentou 2,8 vezes para vacas que já apresentavam metrite, 2,1 vezes para casos de hipocalcemia clínica e 4 vezes para animais com deslocamento de abomaso, quando comparados a vacas sadias. Por outro lado, animais cetóticos tiveram maior chance de desenvolver metrite $(1,8 \mathrm{vez})$ e deslocamento de abomaso (4,5 vezes). Lean et al. (1991) destacaram a natureza bidirecional entre cetose e deslocamento de abomaso, conforme também mostram os dados de outros levantamentos (Grönh, 1996; Detilleux et al., 1997), ou seja, a ocorrência de uma das patologias propicia o aparecimento da outra e vice-versa.

Os triglicerídeos sintetizados no fígado podem ser exportados para a circulação ou armazenados no parênquima hepático, mais especificamente na forma de vacúolos de gordura no citoplasma dos hepatócitos (MacLachlan \& Cullen, 1990). Os triglicerídeos necessitam de uma proteína sintetizada no fígado chamada de VLDL (proteína de densidade muito baixa) para que possam ser lançados na corrente sanguínea e utilizados nos tecidos periféricos. A capacidade do fígado da vaca leiteira em sintetizar VLDL é limitada e pouco responsiva aos aumentos na taxa de esterificação de ácidos graxos no fígado. Segundo Grummer (1993) e Vazquez-Añon et al. (1994), a esteatose hepática, popularmente conhecida como fígado gordo, ocorre 
quando a taxa de síntese de triglicerídios no fígado excede a taxa de desaparecimento, seja por hidrólise ou por liberação na corrente sanguinea por sob a forma de VLDL. Os fatores que regulam o destino dos. AGL no fígado são pouco conhecidos, no entanto fatores que diminuem a oxidação geralmente aumentam a esterificação (Grummer, 1993).

Gerloff et al. (1986) avaliaram 80 vacas em 9 rebanhos no estado de Michigan, as quais foram biopsiadas antes e após o parto, onde $20 \%$ dos animais apresentaram lipidose hepática moderada, 5 a $10 \%$ de TG (triglicerídeo) e 15\% apresentaram lipidose severa, acima de $10 \%$ de TG no tecido hepático. Os animais com lipidose severa apresentaram concentrações de AGL no soro superior aos demais durante o pré e pós-parto, enquanto que os animais com lipidose moderada apresentaram concentrações superiores aos com lipidose branda (<5\% TG) apenas no pós-parto. Dos 12 casos de lipidose severa encontrados, $75 \%$ ( 9 casos) foram encontrados em apenas três propriedades.

Gröhn et al. (1987) separaram 102 animais segundo o percentual de gordura no tecido hepático, maior ou menor que $9 \%$, observando que as vacas com mais de $9 \%$ apresentavam níveis sanguíneos de AST superior $(96,30$; $113,80 \mathrm{UI} / \mathrm{L})$, não sendo observado diferença nos níveis de glicose e $\beta$-hba. Este tipo de diagnóstico é baseado na análise do tecido hepático, portanto é indispensável a execução de biópsia. $O$ alto custo, tempo e a necessidade de profissionais experientes dificultam levantamentos amplos sobre 0 assunto.

Alguns autores (Cebra et al. 1997; West, 1990; West, 1989; Reid et al. 1983) têm tentado relacionar a infiltração gordurosa com parâmetros sanguíneos, no entanto os resultados não são encorajadores até o presente momento, sob o ponto de vista de diagnóstico. Reid et al. (1983) desenvolveu uma fórmula baseada nas concentrações de glicose, AGL e AST. Comparando os resultados obtidos por biópsia hepática, a utilização da fórmula diagnosticou corretamente $75 \%$ dos animais. Pechova et al. (1997), utilizando diferentes 
parâmetros sanguíneos, diagnosticaram corretamente $90 \%$ dos casos quando se basearam na relação sanguínea AGL/TG (positivo se $>4$ ) e $60 \%$ quando utilizaram a fórmula de Reid et. al. (1983), porém estes autores avaliaram apenas 10 animais. West (1990) encontrou correlação positiva $(0,44)$ entre AST sanguíneo e esteatose hepática.

Na grande maioria dos casos, a incidência de hipocalcemia é restrita aos primeiros dias de lactação (Horst et al., 1997), já que está intimamente relacionada à incapacidade da vaca em manter níveis fisiológicos mínimos de cálcio em uma situação de alta demanda para síntese do leite, de ocorrência abrupta, como é o início da lactação. Durante muito tempo as pesquisas deram grande importância para os níveis de cálcio e fósforo nas dietas pré-parto, no entanto, outro mineral foi identificado como crucial para a manutenção de niveis baixos de incidência desta enfermidade, o potássio.

Goff \& Horst (1997a), em um trabalho clássico sobre o assunto, observaram que níveis baixos de cálcio ( $0,5 \% \mathrm{Ca}$ na MS) diminuíam os casos de hipocalcemia, porém associados a níveis altos de potássio $(2,1$ ou $3,1 \% \mathrm{~K}$ na MS) aumentavam a ocorrência da doença a patamares superiores aos observados em dietas com alto nível de cálcio (1,5\% Ca na MS). Em situações onde não é possível fornecer dietas com niveis baixos de cálcio e potássio, sobretudo em função do tipo de volumoso disponível, a utilização de sais aniônicos pode ser uma alternativa (Horst et al. 1997; Beede, 1992).

A incidência de febre do leite é bastante variável entre rebanhos e entre trabalhos, como mostram os dados de Jordan \& Fourdraine (1993), que relatou uma incidência média de $7,2 \%$, porém com uma variação de 0 a $44 \%$. Domecq et al. (1997) relataram uma incidência de 1,4\% em uma fazenda comercial nos EUA, valor próximo a média reportada por Markusfeld (1993) em rebanhos de Israel, porém com uma variação entre 3,5\% (1983) e 1,0\% (1986). 


\subsection{Utilização de aditivos no periodo de transição}

\subsubsection{Monensina sódica}

Por muito tempo tem-se tentado identificar ferramentas que pudessem auxiliar no controle do metabolismo microbiano ruminal, uma vez que a alteração de alguns processos fermentativos no rúmen poderia gerar benefícios na eficiência energética e protéica de ruminantes. Extensivas triagens, através de incubações in vitro e avaliações in vivo, foram realizadas até conseguir identificar moléculas possíveis de produzir os efeitos buscados (Beede \& Farlin, 1977).

Os resultados com antibióticos do grupo dos ionóforos mostraram-se bastante encorajadores neste sentido. As pesquisas evoluíram muito na década de 80 e hoje temos mais de 70 ionóforos identificados, dos quais a monensina sódica (Figura 1) e a lasalocida têm sido os mais amplamente utilizados.

FIGURA 1: Fórmula estrutural da monensina sódica.

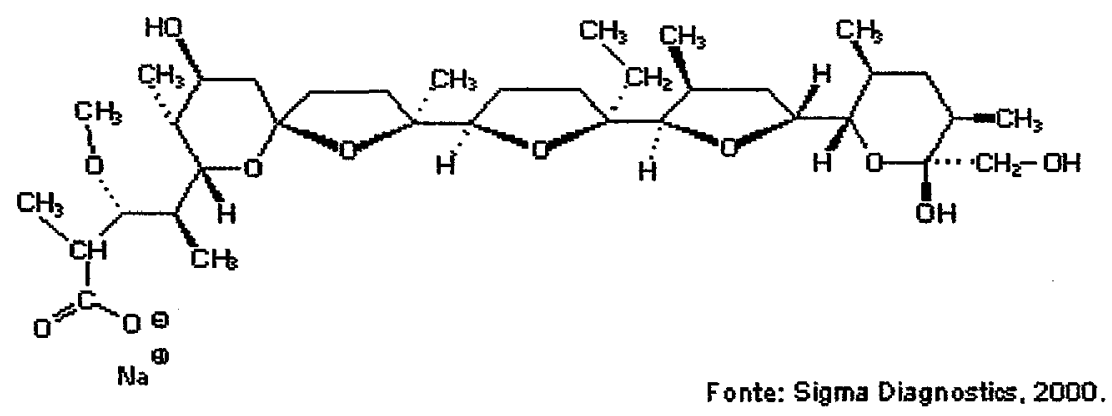

Fórmula química: $\quad \mathrm{C}_{36} \mathrm{H}_{61} \mathrm{O}_{11} \mathrm{Na} \quad$ Peso molecular: $\quad 692,90 \mathrm{~g}$

Os ionóforos são produtos da fermentação de vários actinomicetos, 
geralmente Streptomyces sp. (Bagg, 1997) e, no caso especifico da monensina sódica, o Streptomyces cinnamonensis (Russel, 1997).

O modo de ação dos ionóforos difere da maioria dos antibióticos, basicamente alterando o movimento de íons através de membranas biológicas, podendo então afetar bactérias, protozoários e fungos (Russel, 1997; Schelling, 1984). Em animais ruminantes, a ação se dá sobre bactérias e coccídeos encontrados no rúmen e intestino (Bagg, 1997), mais especificamente, bactérias Gram +, devido à característica menos complexa da membrana plasmática (Russel, 1997; Schelling, 1984). Segundo Schelling (1984), o modo característico de ação originou a nomenclatura deste grupo de antibióticos, "ionophore" ou "ion bearer", transportador de ions.

Os benefícios atribuídos à utilização de ionóforos através da modificação da população microbiana são extensos e, às vezes contraditórios, quando comparamos diferentes autores. Os principais efeitos seriam a diminuição da relação acetato:propionato no rúmen, melhoria da eficiência energética no rúmen através da diminuição na produção de gás metano, diminuição da proteólise e deaminação microbiana e um certo controle do $\mathrm{pH}$ ruminal em dietas com alto teor de carboidratos rapidamente fermentescíveis no rúmen (Russel 1997; Bagg 1997; Sauer et al. 1989; Schelling 1984). Estas alterações são de extremo interesse para ruminantes em geral. No caso de vacas leiteiras, além da possibilidade de proporcionar aumentos em desempenho, poderia ter grande utilidade para animais no período de transição, principalmente no que se refere à prevenção de doenças metabólicas, como cetose e acidose ruminal.

Sauer et al. (1989) avaliaram a utilização de dois níveis de monensina sódica (210 e $400 \mathrm{mg} / \mathrm{vaca} / \mathrm{dia}$ ) fornecidos gradualmente no concentrado, a partir de 1 a 2 semanas antes do parto até a terceira semana de lactação. Estes autores observaram aumento na proporção de propionato, diminuição de acetato e butirato, assim como diminuição na relação acetato:propionato (A:P). A magnitude destes efeitos esteve diretamente relacionada ao nivel de 
monensina empregado, exceto butirato, que foi semelhante para as duas doses empregadas. Green et al. (1999) também encontraram valores menores de butirato, porém apenas uma tendência de menor relação A:P para os animais tratados e pH ruminal superior para o grupo monensina. Os níveis de glicose sanguínea foram semelhantes entre os tratamentos, enquanto os niveis de $\beta$ hba foram menores para as vacas que receberam $400 \mathrm{mg}$.

Ramanzin et al. (1997), em um delineamento fatorial, observaram que a resposta em aumento de propionato ruminal foi maior em vacas que receberam dietas com baixa forragem $(50 \%)$ do que em vacas recebendo $70 \%$ de forragem. Rodrigues (2000) observou comportamento semelhante avaliando três doses de monensina $(0,150$ e $300 \mathrm{mg} / \mathrm{v} / \mathrm{d})$ e três níveis de inclusão de concentrado na dieta $(25,50$ e $75 \%)$. As respostas em propionato ruminal foram maiores, dentro da maior dose de monensina, para vacas em dietas com alto teor de concentrado e o inverso ocorrendo para a dose mais baixa, ou seja, respostas maiores com alta inclusão de forragem na dieta.

Sauer et al. (1989) observaram diminuição de consumo para o nivel mais alto de monensina (400 mg), embora não tenha havido diferença em produção de leite, peso corpóreo e teor de proteína no leite. As vacas que receberam $210 \mathrm{mg}$ apresentaram menor teor de gordura no leite nas três primeiras semanas de lactação, mantendo esta tendência durante toda avaliação. Thomas et al. (1995) fornecendo 4 doses de monensina $(0,150,300$ e 450 $\mathrm{mg} / \mathrm{v} / \mathrm{d}$ ) a partir de 2 a 4 semanas antes do parto, ao contrário de Sauer et al. (1989), observaram diminuição significativa de consumo apenas para as vacas que receberam a menor dose $(150 \mathrm{mg} / \mathrm{v} / \mathrm{d})$, sem no entanto observar efeito sobre produção de leite e sobre os teores de proteína e gordura do leite. Ramanzin et al. (1997) observaram tendência de menor consumo e menor percentual de gordura em vacas tratadas. A produção de leite e 0 teor de proteína foram semelhantes entre os tratamentos, não havendo interação entre as respostas em produção e o nível de forragem da dieta. Green et al. (1999) 
encontraram resultado semelhante no que se refere à produção de leite e teor de proteína, assim como Abe et al. (1994), porém não observaram efeito sobre o teor de gordura, ao contrário do observado por outros (Van der Werf et al., 1998; Abe et al., 1994).

Lean et al. (1994) avaliaram 1061 vacas em 6 rebanhos na Austrália, fornecendo cápsulas de liberação lenta (CLL) ao parto. Observaram efeito positivo sobre produção de leite e tendência para maior produção de proteína e gordura em apenas um dos 6 rebanhos avaliados. Duffield et al. (1999; 1998a; 1998b) conduziram um experimento em 25 fazendas no Canadá, avaliando um total aproximado de 1000 vacas. A monensina sódica foi administrada por CLL 3 semanas antes do parto, não havendo efeito sobre produção de leite, teor de gordura e proteína. Quando os dados de produção foram analisados segundo três categorias de ECC ao parto (magras: $E C C \leq 3,0$; adequadas: $E C C=3,25$ a 3,75 ; gordas: $E C C \geq 4,0$ ), não foi observado resposta para as vacas magras, as vacas com ECC adequado produziram $1,25 \mathrm{~kg}$ de leite/dia a mais no segundo mês de lactação e as vacas gordas produziram $2,5 \mathrm{~kg} /$ dia de leite a mais, em média, nos três primeiros meses de lactação. $O$ fornecimento de monensina também aumentou a produção de leite projetada para 305 dias em rebanhos com maior risco de ocorrência de cetose (Duffield et al., 1999).

Na Austrália foram utilizadas 1109 vacas em 25 rebanhos com o objetivo de avaliar o efeito da utilização de monensina, administrada 40 dias antes da data prevista para o parto por meio de CLL, sobre produção de leite $(n=915)$, desempenho reprodutivo $(n=908)$ e incidência de diversas patologias $(n=686)$, entre elas cetose clínica (Beckett et al, 1998). O fornecimento de monensina aumentou a produção média de leite em 0,75 l/vaca/dia, havendo tendência de aumentos na produção de gordura e proteína, porém sem efeitos sobre o percentual destes constituintes no leite. Não foi observado efeito significativo sobre as variáveis reprodutivas avaliadas, semelhante aos resultados de Lean et al. (1994), fornecendo $M$ (CLL) ao parto. $O$ mesmo resultado foi observado 
para a incidência de patologias, no entanto os animais tratados apresentaram $60 \%$ menos problemas de casco $(15 / 359 ; 25 / 336)$, ou uma incidência $56 \%$ menor $(4,18$ e $7,44 \%)$, porém não diferindo estatisticamente.

É generalizada a idéia de que a utilização de monensina sódica diminui o teor de gordura do leite, apesar de alguns trabalhos não mostrarem efeito significativo (Duffield et al., 1999; Green et al. 1999; Beckett et al, 1998). Kenelly \& Lien (1997) em um levantamento sobre a utilização de ionóforos e composição do leite, avaliaram cinco trabalhos publicados entre 1988 e 1996, três utilizando lasalocida e dois com monensina sódica. Três trabalhos apresentaram diminuição significativa no teor de gordura do leite, sendo que numericamente, em todos os trabalhos foi observado menor teor de gordura para as vacas tratadas, variando entre 0,1 unidade percentual e 0,83 unidade percentual, o mesmo acontecendo com trabalhos mais recentes (Duffield et al., 1999; Green et al. 1999; Beckett et al, 1998).

O aumento na participação de propionato no rúmen, até pouco tempo atrás, serviu para explicar os resultados encontrados em percentual de gordura no leite. Nos últimos anos, diversos autores têm mostrado que este talvez não seja o principal responsável pela diminuição da gordura do leite ou "low fat syndrome".

O aumento no conteúdo duodenal de ácidos graxos insaturados do tipo trans têm sido relacionado com a depressão de gordura do leite (Griinari et al., 1998; Kalscheur et al., 1997). Estes ácidos graxos são intermediários do processo de biohidrogenação no rúmen, portanto, situações que interfiram com o mesmo, como alto teor de concentrado, podem aumentar o fluxo de ácidos graxos trans ao duodeno (Kalscheur et al., 1997), assim como a maior disponibilidade de seus precursores (gordura insaturada) na dieta também (Griinari et al., 1998).

Kube et al. (1988), citado por Kenelly \& Lien (1997), encontraram aumento nas concentrações de ácidos graxos insaturados, linoleico e 
linolênico, em vacas recebendo monensina sódica e também depressão no teor de gordura do leite. Mais recentemente, Fellner et al. (1995) através da incubação de líquido ruminal in vitro, observaram que a infusão de ácido linoleico em meio contendo monensina sódica produziu, aproximadamente, o dobro de ácido octadecenóico $(6,1 \mathrm{mg} / \mathrm{h})$ e quatro vezes menos ácido esteárico $(1,6 \mathrm{mg} / \mathrm{h})$ que no meio controle, 2,9 e $6,1 \mathrm{mg} / \mathrm{h}$, respectivamente. Portanto, a infusão de monensina ao meio reduziu a taxa de biohidrogenação completa do ácido linoleico em esteárico, resultando em maior concentração de ácidos octadecenóico, intermediário no processo de biohidrogenação.

Abe et al. (1994), avaliando 16 vacas que receberam monensina ao parto, encontraram niveis mais baixos de $\beta$-hba para os animais tratados e tendência de maiores niveis de glicose, porém nenhum efeito significativo nos niveis de AGL, uréia e colesterol. Thomas et al. (1993) observaram redução nos níveis urinário e plasmático, de $\beta$-hba e $A G L$, respectivamente, nas primeiras quatro semanas de lactação, para as vacas que receberam 300 e 450 $\mathrm{mg} / \mathrm{d}$ de $\mathrm{M}$, porém não para as que receberam $150 \mathrm{mg} / \mathrm{d}$. Green et al. (1999) forneceram $M(C L L) 21$ dias antes do parto a 52 vacas e, através de restrição alimentar entre a terceira e quinta semana de lactação, induziram o aumento de corpos cetônicos nos animais. Os animais tratados apresentaram maiores níveis de glicose nas 6 semanas pós-parto, menores níveis de $\beta$-hba, assim como tendência de maiores níveis de uréia plasmática pós-parto, possivelmente em decorrência de maior gliconeogênese. Sauer et al. (1989) observaram decréscimo na incidência de cetose clínica e subclínica a medida que aumentaram a dose de monensina sódica, $50 \%$ para a dose zero, $33 \%$ para a dose de $210 \mathrm{mg}$ e $8 \%$ para a dose de $400 \mathrm{mg}$. Os resultados de Duffield et al. (1998b) estão de acordo, mostram uma redução de $50 \%$ na prevalência de cetose subclínica nos animais tratados, considerando positivo niveis plasmáticos superiores a $1200 \mu \mathrm{mol} / \mathrm{ml}$. Quando consideraram niveis mais altos (1400 e $2000 \mu \mathrm{mol} / \mathrm{ml})$, o efeito significativo para os animais tratados 
permaneceu.

\subsubsection{Propileno glicol}

Algumas substâncias gliconeogênicas foram inicialmente utilizadas em ruminantes estritamente para fins terapêuticos, como a glicerina (glicerol) e o propileno glicol; utilizadas no tratamento da acetonemia da vaca leiteira, acetonemia gestacional dos ovinos e como terapia de suporte. Esta prática não é recente e os primeiros trabalhos referentes ao assunto são da década de 50 (Johnson, 1954; Maplesden, 1954).

O uso do propionato de cálcio começou a ser pesquisado mais recentemente, na forma de gel para administração oral ou como componente de dieta total. Além de beneficiar o metabolismo energético, como precursor de glicose, também fornece o íon cálcio, em alta disponibilidade para o animal. Os trabalhos mais recentes têm estudado a suplementação de propionato de cálcio como medida preventiva (Goff et al., 1996) ou curativa (Goff \& Horst, 1995) de doenças metabólicas expressivas do período periparto, como a hipocalcemia.

O propileno glicol ou 1,2-propanodiol é um álcool de aparência cristalina e oleosa, que quando administrado por via oral a ruminantes é parcialmente metabolizado no rúmen. Tem sido utilizado sobretudo na forma de "drench", embora alguns trabalhos tenham avaliado sua inclusão na dieta total ou no concentrado (Laranja da Fonseca et al., 1998; Formigoni et al., 1996; Sauer et al., 1973). A Figura 2 e a Tabela 1 mostram a fórmula estrutural e as características físico-químicas do propileno glicol.

Waldo \& Schultz (1960) avaliaram o comportamento ruminal e sanguíneo de vacas recebendo propileno glicol, propionato de sódio e sacarose. O propileno glicol produziu a maior resposta em glicose sanguínea (60 $\mathrm{mg} / \mathrm{dl}$ ), semelhante estatisticamente ao propionato de sódio $(37 \mathrm{mg} / \mathrm{dl})$, enquanto que a da sacarose foi a mais baixa $(6,0 \mathrm{mg} / \mathrm{dl})$. Propionato de sódio 
mostrou o maior aumento em ácido propiônico no rúmen $(+348 \mathrm{mg} / 100 \mathrm{ml})$, seguido do $P G(+76 \mathrm{mg} / 100 \mathrm{ml})$ e da sacarose $(+31 \mathrm{mg} / 100 \mathrm{ml})$.

FIGURA 2: Fórmula estrutural do Propileno Glicol (PG).

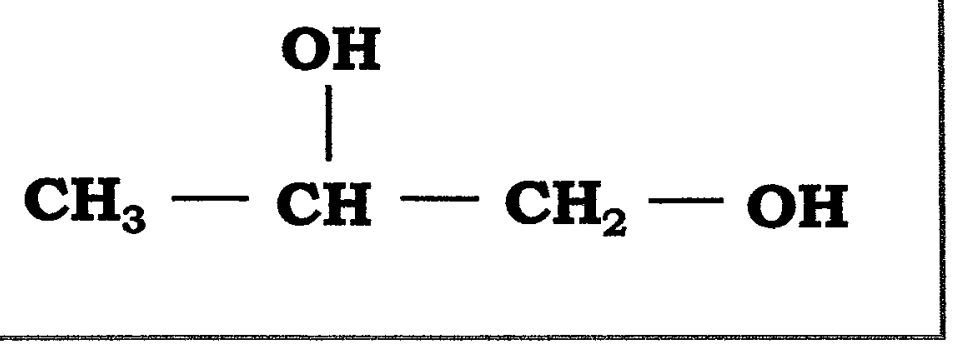

TABELA 1: Características físico-quimicas do Propileno glicol ${ }^{+}$.

\begin{tabular}{llll}
\hline Odor: & inodoro & Peso molecular & $76,09 \mathrm{~g}$ \\
Solubilidade: & solúvel em água & Grav. específica: & 1,0361 \\
Fórmula química: & $\mathrm{C}_{3} \mathrm{H}_{8} \mathrm{O}_{2}$ & Temperatura Solidificação: & $-59^{\circ} \mathrm{C}$ \\
\hline
\end{tabular}

' Sinônimos: 1,2-di-hidroxi-propano; methil glicol; metil-etileno glicol.

Fonte: Sigma, 2000.

Emery et al. (1964), fornecendo até $2,5 \mathrm{~kg}$ de PG aproximadamente, relataram alteração na proporção molar de ácido propiônico $(30,3 \%)$ em relação ao grupo controle $(19,1 \%)$. Waldo \& Schultz (1960) concluíram que o efeito hiperglicêmico do PG era conseqüência, em grande parte, de sua absorção intacta e, em menor grau, da produção de ácido propiônico, portanto sendo uma excelente alternativa para o tratamento de casos clínicos de cetose.

Emery et al. (1964) recuperaram entre 65 a 84\% do PG após 24h de incubação in vitro, porém apenas 32 a $40 \%$ quando incubaram por $3 \mathrm{~h}$ em líquido ruminal de vacas que vinham recebendo PG por três semanas. Czerkawski \& Breckenridge (1973) observaram efeito da dieta sobre a 
utilização do PG em incubação in vitro por $4 \mathrm{~h}: 22 \%$ de utilização em uma dieta a base de feno, $49 \%$ quando incluíram concentrado e $100 \%$ quando incluíram polpa de beterraba. Estes trabalhos sugerem que a população microbiana predominante pode afetar a degradação do PG no rúmen, que segundo Czerkawski \& Breckenridge (1973) estaria relacionado ao metabolismo da ramanose, uma vez que ambos seriam metabolizados por rotas semelhantes.

Os protocolos experimentais para utilização de PG têm sido os mais variados possiveis: durante a lactação, durante o período pré-parto somente ou uma combinação destes dois, com freqüência, volume e forma de fornecimento distintos.

Sauer et al. (1973) trabalhando com diferentes niveis de propileno glicol $(0,3,6$ e $9 \%)$ adicionado ao concentrado durante as primeiras oito semanas de lactação, observaram uma redução de testes positivos para cetose subclínica no leite $(26,7 \%, 17,2 \%, 5,6 \%$ e $6,3 \%)$, respectivamente. Semelhante também foi o resultado em AGL sanguíneo, menores para os níveis de 6 e $9 \%$, embora - nivel de $3 \%$ tenha sido semelhante aos demais em diminuir os níveis plasmáticos de $\beta$-hba em relação ao controle.

Os conhecimentos gerados no final da década de 80 e início de 90 sobre o metabolismo energético de animais no periodo de transição influenciaram as pesquisas subseqüentes. A utilização de propileno glicol começou a ser avaliada mais intensamente durante o período pré-parto, uma vez que a mobilização de tecido corporal tem início já nas últimas semanas de gestação (Tesfa et al., 1999; Bertics et al., 1992).

Studer et al. (1993) forneceram um litro durante os $10 \pm 3,6$ dias antes do parto e observaram redução significativa nos niveis plasmáticos de $\beta$-hba e $A G L$, assim como aumento nas concentrações de insulina, durante o período de fornecimento. As vacas tratadas com PG apresentaram também menor quantidade de TG hepático ao $1^{\circ}$ e $21^{\circ}$ dia de lactação. Não houve diferença significativa para os parâmetros sanguíneos avaliados durante a lactação, 
embora os níveis de $A G L$ tivessem mantido o mesmo padrão observado durante o periodo de fornecimento do PG. Formigoni et al. (1996) fornecendo $300 \mathrm{~g}$ na dieta total durante o período pré-parto e sob a forma de "drench" durante os primeiros 12 dias de lactação, não observaram diferença nos níveis sanguíneos de $\beta$-hba e insulina, já os animais tratados tiveram concentraçōes menores de AGL durante a lactação, ou seja, apenas durante o período em que foi administrado sob a forma de "drench".

Laranja da Fonseca et al. (1998) fornecendo PG (300ml) sob a forma de "drench", durante o pré-parto e início de lactação, não observaram efeito significativo nas concentrações plasmáticas de $\beta$-hba, AGL e glicose, nem tão pouco efeito sobre a incidência de cetose subclínica e intervalo entre o parto e primeiro cio. No entanto, estes autores observaram maior produção de leite na quarta e quinta semanas de lactação para as vacas do tratamento PG.

Até meados da década de 90 , os trabalhos demonstraram o efeito gliconeogênico e hiperinsulinêmico do $P G$, porém não haviam resultados disponíveis a respeito da dose mínima e via de administração mais indicada. Gummer et al. (1994) avaliaram a utilização de quatro níveis de propileno glicol $(0,296,592$ e $887 \mathrm{ml})$ aplicados via oral em novilhas holandesas sob restrição alimentar, 50 a $70 \%$ do consumo voluntário. A restrição alimentar mimetizou as alterações de consumo e metabolismo energético que normalmente ocorrem em vacas nas três semanas que antecedem ao parto. Estes autores encontraram efeito linear de doses de propileno glicol nos níveis plasmáticos de glicose, insulina, $\beta$-hba e AGL. A maior resposta por mililitros de propileno glicol ocorreu na dose de $296 \mathrm{ml}$, embora apenas a maior dose (887 $\mathrm{ml}$ ) tenha sido eficiente em gerar valores semelhantes aos encontrados antes da restrição alimentar. Por fim, Grummer et al. (1994) concluíram que $296 \mathrm{ml}$ são quase tão eficientes quanto $887 \mathrm{ml}$ em reduzir os níveis plasmáticos de AGL quando comparados ao controle, respectivamente $(425,282$ e $746 \mu \mathrm{eq} / \mathrm{L})$.

Christensen et al. (1997) fornecendo $2,5 \mathrm{ml}$ de propileno glicol por quilo 
de peso metabólico ( $341 \mathrm{ml}$ para vacas e $307 \mathrm{ml}$ para novilhas), avaliaram diferentes formas de fornecimento ("drench", no concentrado e na dieta total). A administração sob a forma de "drench" ou no concentrado, produziram niveis de insulina superiores aos observados com a administração de PG na dieta total e também foram mais eficientes em reduzir AGL em vacas sob restrição alimentar, porém não encontraram diferenças para $\beta$-hba e glicose. Enquanto as respostas em insulina e glicose têm sido bastante consistentes entre os diferentes autores, o pico de glicose ou insulina após o fornecimento, quando PG é administrado sob a forma de "drench", varia bastante entre os trabalhos.

Christensen et al. (1997) observaram que o pico de glicose e insulina ocorreu 90 e 180 minutos após o fornecimento, respectivamente. Grummer et al. (1994) observaram a ocorrência do pico de insulina aos 15 minutos após o fornecimento para as diferentes quantidades de $P G$ avaliadas. $O$ momento do pico de glicose ocorreu antes (15 minutos) em vacas que receberam $296 \mathrm{ml} \mathrm{e}$, aos 30 minutos para vacas recebendo 592 ou $887 \mathrm{ml}$. Studer et al. (1993) também relataram a ocorrência do pico de glicose e insulina, 75 e 30 minutos após, respectivamente, para vacas recebendo 1 litro de PG.

A capacidade de inibir a mobilização de gordura, diminuir a infiltração de triglicerídios no fígado e, em alguns casos, diminuir os niveis de $\beta$-hba e de cetose subclínica são resultados que sugerem um potencial benefício também sobre produção de leite. Os dados de produção e composição de leite são mais restritos na literatura que as avaliaçōes de perfil sanguíneo, ainda mais se tratando de fornecimento exclusivamente antes do parto. Emery et al. (1964) observaram efeito sobre produção de leite em apenas um dos três rebanhos avaliados. Trabalhos mais recentes (Birchen et al., 2000; Formigoni et al., 1996; Studer et al., 1993; Fisher et al., 1973) não foram capazes de encontrar diferença em produção de leite e seus componentes.

Fisher et al. (1973) suplementaram diferentes niveis de PG no concentrado $(0 ; 3 ; 6$ e $9 \%)$ durante o início de lactação, encontrando maior teor 
de lactose para as vacas que receberam 9\% de propileno glicol quando comparado aos tratamentos controle e $3 \%$. Houve tendência de os animais tratados apresentarem menores concentrações de gordura no leite, diferindo em apenas três coletas de um total de oito. Em geral, o nivel de $6 \%$ de propileno glicol apresentou os menores teores. Os níveis de 6 e $9 \%$ apresentaram valores $(3,20 ; 3,72 \%)$ inferiores aos niveis 0 e $3 \%(4,09 ; 4,37 \%)$ na primeira semana, possivelmente consequiência de maior mobilização de gordura nas vacas do tratamento controle e 3\%. Birchen et al. (2000) forneceram $228 \mathrm{ml}$ de PG sob a forma de "drench" para vacas Jersey a partir de uma semana antes do parto até a primeira semana de lactação, observando maior concentração de glicose ao parto, menores concentrações de $\beta$-hba $e$ menor perda de condição corporal para as vacas tratadas.

Os trabalhos com PG têm mostrado um efeito mais consistente sobre os parâmetros sanguíneos e incidência de cetose, enquanto que as respostas em produção e composição do leite são variáveis e menos freqüentes.

\subsection{Balanço energético e desempenho reprodutivo}

Em qualquer atividade pecuária o desempenho reprodutivo é de extrema importância, visto que dele depende o estabelecimento de uma nova lactação, a reposição, o crescimento do rebanho e a receita com a venda de animais.

A medida que o potencial produtivo das vacas leiteiras aumentou nas últimas décadas, trouxe consigo uma maior dificuldade no manejo reprodutivo destes animais, como por exemplo, a manutenção dos índices de taxa de concepção. (Butler 2000; Butler \& Smith, 1989). O reflexo negativo sobre taxa de concepção foi da ordem de 15 pontos percentuais segundo os dados levantados por Butler \& Smith (1989). Estes autores compararam os dados de produção anual de leite $(4.500 \mathrm{~kg} / \mathrm{v} / \mathrm{ano})$ e taxa de concepção $(66 \%)$ em rebanhos do Estado de Nova York em 1950, com dados mais recentes, de 
1985. Enquanto a produção anual de leite aumentou para 8000 a 8500 $\mathrm{kg} / \mathrm{v} / a n o$, as taxas de concepção caíram para 52 a 49\% (Butler \& Smith, 1989).

Os efeitos do aumento de produção de leite sobre desempenho reprodutivo estão associados basicamente, com dois fatores: alterações nos perfis hormonal e metabólico, assim como aumento no défice energético no início de lactação, os quais são intimamente relacionados (Santos, J. 1996). No início de lactação, as vacas apresentam incapacidade de atender as exigências energéticas e protéicas exclusivamente através do consumo de alimento, portanto, utilizam as reservas corporais para preencher esta lacuna (Komaragiri \& Erdman, 1997; Stevenson et al., 1997; Santos, J. \& Amstalden, 1997; Grummer, 1995). Na grande maioria dos casos, o extremo de balanço energético negativo (BEN) ocorre durante a primeira e segunda semanas de lactação (Zurek et al., 1995; Butler \& Smith, 1989; Villa-Godoy et al., 1988) e, ao redor de 40 a 50 dias de lactação, as vacas já apresentam um equilíbrio entre a demanda e o consumo de nutrientes (De Vries \& Veerkamp, 2000; Staples et al. 1990), com balanço energético (BE) próximo de zero.

Butler \& Smith (1989) salientaram a alta correlação negativa entre balanço energético médio e produção de leite $(r=-0,8)$, sugerindo então que animais de maior mérito genético, estariam, inevitavelmente, sujeitos a ovulações mais tardias. Staples \& Thatcher (1997), utilizando dados de uma avaliação anterior (Staples et al., 1990), observaram que as vacas em anestro consumiram menos, entre 2,5 a $3,6 \mathrm{~kg}$ de MS, do que as vacas que estavam ciclando, em concordância com o observado por Zurek et al. (1995). VillaGodoy et al. (1988) observaram que a variação no BEN médio, em vacas no início de lactação, esteve mais intimamente relacionada com consumo de matéria seca que com produção de leite, $r=0,73$ e $r=-0,25$, respectivamente. Portanto, embora exista efeito negativo de produção de leite sobre $B E$, as alterações em consumo de matéria seca explicam melhor este parâmetro.

A relação entre $B E$ no início de lactação e o dia para ocorrência da 
primeira ovulação é claramente demonstrada em diferentes trabalhos (Zurek et al., 1995; Canfield et al., 1990; Butler et al., 1981), observando-se a ovulação, em média, entre 10 (Butler et al., 1981) e 15 dias (Zurek et al., 1995) após o dia de maior défice energético ("nadir"). Entre as diferentes formas de expressar o $B E$, a que apresenta maior correlação linear com dias para primeira ovulação é o número de dias para atingir o valor extremo de $B E N$, com coeficientes que variam entre 0,55 a 0,75 (Beam \& Butler, 1997; Zurek et al., 1995; Canfield et al., 1990).

Zurek et al. (1995) avaliaram outras variáveis relacionadas ao balanço energético, como o BE médio do parto à ovulação, o BE mais extremo ("nadir") e o BE no dia da ovulação. Estes autores não encontraram correlação significativa para as duas primeiras variáveis e uma menor correlação $(r=0,49)$ para a última, quando comparada ao 0,61 encontrado em relação aos dias para o extremo de BEN.

O tempo decorrido do parto ao início da atividade ovariana é importante pois possibilita a manutenção de um intervalo entre partos adequado, melhor taxa de concepção e menor serviços por prenhes (Thatcher \& Wilcow, 1973). Segundo estes autores, vacas $(n=1209)$ que apresentaram maior número de cios antes da inseminação aos 60 dias pós-parto (até 4 cios vs 0 ), tiveram uma maior taxa de não retorno após inseminação ( 47 vs $34 \%$ ) e menor serviços por prenhes $(2,21$ vs $2,60 \%)$.

Butler et al. (1996) observaram maiores concentrações plasmáticas de progesterona em vacas prenhes que em vacas vazias, enquanto Villa-Godoy et al. (1988) observaram que a taxa de aumento nas concentrações de progesterona ao longo da lactação esteve reduzida em vacas de maior BEN (-6 Mcal). Outro efeito importante do BEN sobre fertilidade pode ser através das concentrações de progesterona (Butler, 2000; Santos \& Amstalden, 1999), as quais podem estar diminuídas em vacas em BEN (Santos, J. 1997). Britt et al. (1996) observaram uma interação entre embriōes coletados e concentração de 
progesterona plasmática em vacas ciclando, $28,6 \%$ e $85,7 \%$, no menor e maior quartil de progesterona plasmática, respectivamente.

As conseqüências do BEN sobre o início da atividade ovariana são claramente evidenciadas, porém a maneira pela qual este evento se desenvolve, os pontos de controle e a hierarquia hormonal envolvidos no processo são aspectos mais complexos e ainda pouco conhecidos.

Segundo Stevenson \& Britt (1979), citados por Santos, J. (1996), o restabelecimento da secreção de hormônio luteinizante (LH) pela hipófise anterior é o fator chave para início da atividade ovariana após o parto. Schillo (1992) sugeriu que uma das maneiras pela qual o BEN influencia negativamente a atividade ovariana seria pela supressão do aumento nas frequências pulsáteis de $\mathrm{LH}$, possivelmente através do controle da secreção do hormônio liberador de LH (LHRH) pelo hipotálamo. Vacas em BEN apresentam uma série de alterações características no metabolismo intermediário e, por conseguinte, no perfil sanguíneo destes metabólitos e de alguns hormônios, os quais podem funcionar como estimuladores ou inibidores da secreção de $\mathrm{LH}$ (Stevenson et al., 1997; Schillo, 1992).

Enquanto os niveis sanguíneos de AGL e AST estiveram negativamente correlacionados, as concentrações de glicose, tirosina e IGF-I apresentaram correlação positiva com a frequência pulsátil de LH (Beam, 1996; Zurek et al., 1995; Schillo, 1992). Beam (1996) também observou que a atresia do folículo dominante esteve relacionada ao dia de ocorrência do extremo de BEN, à redução na freqüência pulsátil de $\mathrm{LH}$ e às baixas concentrações de IGF-I e estradiol. Beam \& Butler (1997) observaram que as concentraçōes de IGF-I foram 40 a $50 \%$ maiores durante as 2 primeiras semanas de lactação em vacas que ovularam do que em vacas que não ovularam.

Spicer et al. (1990) observaram que vacas em BEN (-1,69 Mcal/d) apresentaram menor concentração de IGF-I e menor concentração de progesterona plasmática durante a fase lútea, quando comparadas a vacas em 
BE positivo (3,43 Mcal/d). $0^{\circ}$ Callaghan \& Boland (1999) salientaram a estreita relação direta entre as concentrações sanguíneas de IGF-I e insulina.

Para a quantificação do balanço energético é indispensável a determinação do consumo voluntário de MS diário dos animais, no entanto este tipo de procedimento é extremamente trabalhoso, requer instalações específicas e, portanto, difícil de ser avaliada em rebanhos comerciais.

No intuito de possibilitar uma estimativa do balanço energético de vacas em início de lactação, mais simples e econômica, alguns pesquisadores têm buscado correlacioná-lo com constituintes do leite (De Vries \& Veerkamp, 2000) enquanto outros têm tentado utilizar parâmetros sanguíneos como indicadores de balanço energético (Zurek et al. 1995; Miettinen, 1991). Segundo de Vries \& Veerkamp (2000) e Zurek et al. (1995), o melhor indicador de balanço energético seria o percentual de gordura do leite, mais precisamente o decréscimo no percentual de gordura do leite (De Vries \& Veerkamp, 2000). Estes autores, avaliando 470 vacas de primeira lactação, encontraram alta correlação entre o decréscimo no percentual de gordura do leite e o valor extremo de $B E N$, défice energético médio e dia para retorno ao balanço energético positivo. Entre estes parâmetros, a correlação mais consistente ao longo das 15 primeiras semanas de lactação foi com o valor extremo de BEN ( $r=0,44$ a 0,52$)$.

Em vacas leiteiras, o desenvolvimento folicular antes da primeira ovulação pode resultar em ovulação do folículo dominante, várias ondas foliculares com um folículo dominante anovulatório ou a formação de um cisto ovariano (Savio et al., 1990; Butler, 2000).

A atividade ovariana tem sido avaliada através da interpretação das concentrações de progesterona no plasma ou leite (Heinonen et al., 1988; Opsomer, 1998; Bekana, 1997) e, mais detalhadamente, pelo exame de imagens obtidas com aparelhos de ultrassonografia (Pierson \& Ginther, 1984; Edmondson et al., 1986). Alguns trabalhos têm utilizado ambas as avaliações 
(Son et al., 1995; Rajamahendran \& Taylor, 1990; Battochio et al., 1999), possibilitando estudar os efeitos de cisto folicular e corpo lúteo (CL) persistente sobre as concentrações de progesterona e também correlacionando área de CL e progesterona.

A correlação entre área de $\mathrm{CL}$ e nível de progesterona é alta na maioria dos trabalhos, variando entre 0,60 a 0,88 , segundo a fonte consultada (Santos, J. 1997; Son et al., 1995; Rajamahendran \& Taylor, 1990). Rajamahendran \& Taylor (1990) não encontraram correlação entre estes dois parâmetros no primeiro ciclo estral, apenas no segundo $(r=0,88)$. Son et al. (1995) obtiveram maior correlação $(0,75$ vs 0,69$)$ quando descartaram os dados em que o $C L$ apresentava-se cístico (área central não ecogênica), sendo que ambos mostraram alta correlação.

Diversos protocolos de coleta de amostra e interpretação dos resultados têm sido utilizados quando nos reportamos aos niveis de progesterona. Geralmente, tem-se utilizado como parâmetro de início de atividade ovariana niveis plasmáticos de progesterona entre 0,5 e 1,0 ng/ml em pelo menos duas coletas consecutivas, ou com um padrão crescente ao longo das coletas seguintes. A freqüência de coleta é variável, dependendo de questões operacionais e do objetivo do trabalho. 


\section{OBJETIVOS}

Avaliar o efeito da administração de propileno glicol e monensina sódica para vacas leiteiras, exclusivamente durante o período pré-parto, sobre a produção e composição do leite nas primeiras nove semanas de lactação; sobre os parâmetros sanguíneos, desempenho reprodutivo, incidência de distúrbios metabólicos e incidência de mastite clínica. 


\section{MATERIAL E MÉTODOS}

\subsection{Animais e instalações experimentais}

O experimento foi conduzido no rebanho de gado leiteiro do Departamento de Produção Animal, da Escola Superior de Agricultura "Luiz de Queiroz" da Universidade de São Paulo.

Foram avaliadas quarenta e quatro vacas Holandesas, multíparas, do dia da secagem dos animais até a nona semana de lactação. Logo após a secagem, os animais foram mantidos em um piquete de 3 ha com fornecimento de dieta total no cocho. Aos 35 dias antes da data prevista para o parto, as vacas foram transferidas para o piquete maternidade, o qual dispunha de área gramada para exercício e descanso, além de um galpão coberto, com piso de concreto, cocho de água e de alimento. Após o parto, as vacas eram imediatamente transferidas para uma instalação de estabulação livre ("freestall") e ali mantidas até o final do periodo experimental, na nona semana de lactação.

\subsection{Tratamentos e delineamento experimental}

Foi utilizado o delineamento em blocos casualisados incompletos, onde cada vaca constituiu uma unidade experimental. Os animais foram bloqueados de acordo com a data prevista para o parto, de modo que a diferença não fosse maior que dez dias dentro de cada bloco. Em função do pequeno número de 
animais disponiveis, sempre que possivel, também foi levado em consideração a produção de leite na lactação anterior e a condição corporal à secagem, totalizando 15 blocos. Cada bloco foi constituído de três vacas, uma de cada tratamento, que obedecessem aos critérios anteriormente estabelecidos. Os animais foram submetidos a três tratamentos: o tratamento controle (C), o tratamento monensina sódica (M) e o tratamento propileno glicol (PG).

A monensina sódica foi administrada aos 35 dias antes da data prevista para o parto através de uma cápsula intraruminal de liberação lenta, contendo $32 \mathrm{~g}$ de monensina sódica (Rumensin ${ }^{\circledR} A B C^{1}$ ), que fornece $335 \pm 33 \mathrm{mg} / \mathrm{d}$ de monensina sódica por 95 a 120 dias (Green et al., 1999). O propileno glicol foi fornecido a partir dos 21 dias antes da data prevista para o parto, na quantidade de $300 \mathrm{ml} / \mathrm{vaca} / \mathrm{dia}$, sob a forma de "drench".

A fim de restringir a comparação entre os tratamentos exclusivamente ao período pré-parto, as vacas dos tratamentos controle e PG receberam uma cápsula de monensina sódica dentro de no máximo 24 horas após o parto, ou seja, todas as vacas estiveram expostas ao efeito da monensina sódica durante o período de lactação.

\subsection{Periodo e dietas experimentais}

O período de avaliação estendeu-se do dia 8 de janeiro até o dia 14 de setembro de $1999,63^{\circ}$ dia de lactação da $44^{a}$ vaca. Todos os tratamentos receberam a mesma dieta de acordo com a fase fisiológica em que se encontravam, vacas secas (60 a 36 dias antes da data prevista para o parto), vacas pré-parto (de 35 dias antes do parto até o parto) e vacas em lactação. As dietas foram formuladas a fim de atender às exigências de $E L_{L}, P B, F D N, F D A$, minerais e vitaminas estabelecidos pelo NRC (1989) (Tabela 2 e 3) Algumas adaptações foram feitas na dieta pré-parto, conforme sugerido por outros

\footnotetext{
Elanco Saúde Animal, Eli Lilly do Brasil Ltda.
} 
autores (Hutjens, 1996; Grummer, 1995). Os niveis nutricionais das respectivas dietas foram mantidos ao longo de todo período experimental.

As amostras de ração completa foram compostas em amostras mensais e então analisadas, resultando em 5 amostras da fase pré-parto (Fevereiro a Junho de 1999) e 6 amostras do período de lactação (Março a Agosto de 1999), valores médios presentes na Tabela 2.

TABELA 2: Composição (média \pm EPM) das dietas totais fornecidas nos respectivos períodos.

\begin{tabular}{|c|c|c|}
\hline \multirow{2}{*}{ Nutrientes (\%) } & Pré-parto ${ }^{1}$ & Início de lactação $^{2}$ \\
\hline & Fev a Jun 1999 & Mar a Ago1999 \\
\hline Matéria Seca, \% & $33,91 \pm 0,62$ & $44,46 \pm 1,75$ \\
\hline Proteína Bruta, \% & $14,76 \pm 0,44$ & $20,66 \pm 0,95$ \\
\hline Extrato etéreo, \% & $2,20 \pm 0,26$ & $3,56 \pm 0,62$ \\
\hline Cinzas & $6,73 \pm 0,76$ & $8,13 \pm 0,18$ \\
\hline FDN & $39,03 \pm 1,08$ & $29,38 \pm 0,36$ \\
\hline FDA & $24,21 \pm 0,57$ & $19,73 \pm 0,56$ \\
\hline NDT & $61,49 \pm 0,75$ & $67,35 \pm 0,85$ \\
\hline \multicolumn{3}{|l|}{ Minerais } \\
\hline Cálcio & $0,399 \pm 0,04$ & $0,810 \pm 0,07$ \\
\hline Fósforo & $0,323 \pm 0,01$ & $0,512 \pm 0,035$ \\
\hline Potássio & $0,995 \pm 0,06$ & $1,34 \pm 0,07$ \\
\hline Magnésio & $0,192 \pm 0,01$ & $0,307 \pm 0,01$ \\
\hline Enxofre & $0,190 \pm 0,01$ & $0,252 \pm 0,01$ \\
\hline Sódio & $0,204 \pm 0,01$ & $0,298 \pm 0,08$ \\
\hline Cloro & $0,594 \pm 0,016$ & ----- \\
\hline $\mathrm{BCA}^{3}(\mathrm{mEq} / 100 \mathrm{~g} \mathrm{MS})$ & $5,74 \pm 1,188$ & --.-- \\
\hline
\end{tabular}

${ }^{1}$ Média de 5 amostras, compostas por mês.

${ }^{2}$ Média de 6 amostras, compostas por mês.

${ }^{3}$ Balanço catiônico-aniônico médio da dieta pré-parto, calculado segundo Beede (1992) 4 .

${ }^{4} \mathrm{BCA}=[(\mathrm{mEq} \mathrm{Na}+\mathrm{mEq} \mathrm{K})-(\mathrm{mEq} \mathrm{Cl}+\mathrm{mEq} \mathrm{S})]$ 
As amostras de alimento foram secas a $55^{\circ} \mathrm{C}$ durante $72 \mathrm{~h}$, moídas em moinho tipo "Willey" com peneira de $1 \mathrm{~mm}$ e analisadas para MS, MO, PB e extrato etéreo (EE) de acordo com o AOAC (1990), fibra em detergente neutro (FDN) e fibra em detergente ácido (FDA) de acordo com Van Soest et al. (1991). As análises de minerais, exceto cloro, foram feitas pelo Laboratório de Solos e Nutrição de Plantas da Escola Superior de Agricultura "Luiz de Queiroz", Universidade de São Paulo. A determinação de cloro foi feita em um laboratório comercial.

TABELA 3: Composição das dietas experimentais.

\begin{tabular}{lcc} 
& \multicolumn{1}{c}{ Pré-parto } & Lactação \\
\cline { 2 - 3 } & & (\%) da MS \\
\hline Silagem de Milho & 33,40 & 39,65 \\
Cana de açúcar & 36,00 & 5,30 \\
Feno de gramínea & ---- & 4,90 \\
Caroço de algodão & ---- & 10,20 \\
Milho grão, moído fino & 5,80 &.-- \\
Polpa cítrica & 3,05 & 8,10 \\
Pipoca doce, resíduo de & 10,00 & 11,65 \\
Farelo de Soja & 8,65 & 17,20 \\
Uréia & 1,35 & 0,35 \\
Sal Mineral comercial & 1,75 & 2,65 \\
\hline
\end{tabular}

\subsection{Análise estatística}

Dois animais do tratamento monensina sódica não foram incluídos nas análises reprodutivas e de cetose subclínica por terem apresentado problemas graves no sistema locomotor. Apenas os dados de produção da fase anterior ao aparecimento do problema e os dados do período pré-parto foram incluídos. 
Uma vaca do tratamento controle não foi avaliada em função de parto antecipado, portanto resultando em um bloco incompleto, totalizando assim as 44 vacas distribuídas em 15 blocos.

Todos os dados foram testados para distribuição normal dos erros, à exceção das variáveis com resposta do tipo tudo ou nada, utilizando-se o PROC UNIVARIATE do pacote estatístico SAS 6.11 (1991). Os dados atenderam a exigência de normalidade dos resíduos quando a probabilidade para o teste de Shapiro-Wilk foi maior ou igual a $10 \%$, do contrário os dados foram submetidos à transformação matemática, na seguinte ordem: logaritmo na base $10(\log 10)$, raiz quadrada e inverso da raiz quadrada. A transformação que produziu a maior probabilidade foi então aplicada aos dados, conforme sugerido por outros autores (Alves, 1999; SAS, 1991).

TABELA 4: Análise de variância para as variáveis de produção e composição do leite.

\begin{tabular}{lc}
\multicolumn{1}{c}{ Causas de Variação } & Graus de Liberdade \\
\hline Tratamento & 2 \\
Bloco & 14 \\
Resíduo A & 27 \\
\hline Parcelas & 43 \\
\hline Tempo & 8 \\
Tempo x Tratamento & 16 \\
Resíduo B & 328 \\
\hline TOTAL & 395 \\
\hline
\end{tabular}

Os dados de produção e composição de leite e parâmetros sanguíneos foram analisados utilizando-se o PROC MIXED do pacote estatístico SAS (1991). Para tanto, os efeitos de tratamento e bloco foram testados com relação 
às parcelas, sendo o efeito de bloco inserido no modelo como efeito aleatório, através da função "random". O dia de coleta (tempo), a covariável (35 dias antes do parto) e a interação tempo $x$ tratamento, foram testados em relação as subparcelas, à exceção dos dados de produção e composição do leite que não foram ajustados para o efeito de covariável.

TABELA 5: Análise de variância para as variáveis com resposta do tipo tudo ou nada.

\begin{tabular}{lc} 
Causas de Variação & Graus de Liberdade \\
\hline Tratamento & 2 \\
Bloco & 14 \\
Resíduo A & 27 \\
\hline TOTAL & $\mathbf{4 3}$ \\
\hline
\end{tabular}

TABELA 6: Análise de variância para os parâmetros sanguíneos.

\begin{tabular}{lc}
\multicolumn{1}{c}{ Causas de Variação } & Graus de Liberdade \\
\hline Tratamento & 2 \\
Bloco & 14 \\
Co-variável & 1 \\
Resíduo A & 26 \\
\hline Sub TOTAL & 43 \\
\hline Tempo & 7 \\
Tempo x Tratamento & 14 \\
Resíduo B & 287 \\
\hline TOTAL & 351
\end{tabular}

Para variáveis com resposta do tipo tudo ou nada, como retenção de 
placenta por exemplo, utilizou-se o mesmo modelo acima descrito, sem o feito de tempo e covariável, atribuindo-se o valor um (1) para os animais positivos e o valor zero (0) para os animais negativos. As análises de regressão foram feitas utilizando-se o PROC GLM.

Quando foram detectadas respostas significativas para a interação tempo $\times$ tratamento segundo o Teste $F$, avaliou-se a diferença entre tratamentos nos diferentes tempos de coleta, a menos que descrito de outra forma. Os resumos dos quadros de análise de variância estão apresentados nas Tabelas 4, 5 e 6.

Considerou-se o nível de $6 \%$ de significância como significativo e até $16 \%$ como tendência, para os valores de probabilidade do teste $\mathrm{F}$. Todos os resultados mostrados são médias obtidas pelo método dos quadrados mínimos.

\subsection{Procedimentos de coleta e métodos analíticos}

4.5.1 Metodologia de coleta de sangue para as análises de glicose, AGL, insulina, $\beta$-hba e AST.

As coletas de sangue foram iniciadas 35 dias antes da data prevista para o parto, a segunda coleta foi realizada aos 21 dias e, a partir de então, a cada três dias até o dia do parto. A intensificação das coletas a partir de 21 dias antes da data prevista para o parto teve como objetivo diminuir uma possivel variação decorrente de partos antecipados, uma vez que somente foram utilizadas para análise as amostras de sangue dos dias $35,21,14,7,3$ e ao parto. As amostras do dia do parto foram colhidas dentro de no máximo 24 horas. Durante o período de lactação, as amostras de sangue foram colhidas aos 7, 14 e 21 dias. A colheita se deu sempre antes da alimentação, entre 5:30h e 8:00h da manhã, e para os animais em lactação após a ordenha da manhã, no mesmo horário. As vacas do tratamento Propileno Glicol tiveram o 
sangue coletado 90 minutos após o fornecimento do produto.

O sangue foi colhido em tubos a vácuo de $5 \mathrm{ml}$ contendo anticoagulante (5 $\mathrm{mg}$ de oxalato de potássio) e antiglicolítico (5 $\mathrm{mg}$ de fluoreto de sódio) (Vacuum II; Labnew Indústria e Comércio Ltda.,São Paulo, Brasil). As amostras foram centrifugadas a $2000 \mathrm{G}$ dentro de no máximo 1 hora e o plasma armazenado em 4 tubos de $2 \mathrm{ml}$ do tipo "eppendorf", um tubo para cada análise. As amostras de plasma foram congeladas a $-20{ }^{\circ} \mathrm{C}$ até serem analisadas.

\subsubsection{Metodologia para determinação de glicose}

A determinação de glicose foi feita em um analisador bioquímico YSI 2700-S BioChem (Yellow Springs Instrument Co. Inc., Ohio, EUA) no Laboratório de Bromatologia do Departamento de Produção Animal da ESALQUSP. As amostras, logo após serem pipetadas na placa de E.L.I.S.A. (Enzymelinked immusorbent assay) para análise de AGL, tiveram sua concentração de glicose determinada no referido aparelho. Para este procedimento não foi utilizado controle de qualidade ou solução padrão.

\subsubsection{Metodologia para determinação de insulina}

As análises de insulina foram conduzidas no Laboratório de Nutrição Animal do Centro de Energia Nuclear na Agricultura da Universidade de São Paulo (CENA-USP). A concentração plasmática de insulina foi determinada em duplicata, através da técnica de radioimunoensaio (RIA) utilizando o kit comercial CAC em fase sólida (Insulina Coat-a-Count, Diagnostics Products Co., Los Angeles, CA, USA), lote TIN1 276, vencimento em 31 de maio/2000. Cada ensaio foi constituído de 100 tubos, 80 tubos para as amostras a serem determinadas e o restante para os padrões segundo recomendado por este fabricante, à exceção dos tubos de ligação não específica (NSB). Foram 
utilizados dois controles de qualidade provenientes de uma vaca em lactação, a qual foi puncionada antes do fornecimento do alimento e duas horas após a alimentação. Posteriormente foram congelados em alíquotas e utilizados em todos os ensaios. Os controles de qualidade foram alocados no início e no fim de cada ensaio, porém não foi utilizada duplicata. $O$ coeficiente de variação médio dentro de ensaio foi $5,34 \%$ e de $7,42 \%$ entre os ensaios.

\subsubsection{Metodologia para determinação de AGL}

As análises de AGL foram conduzidas no Laboratório de Bromatologia da Escola Superior de Agricultura "Luiz de Queiroz" (ESALQ-USP). A concentração plasmática de AGL foi determinada em duplicata, através da utilização de um kit comercial, (Wako Chemicals $\mathrm{GmbH}$, Neuss, Alemanha), lote $n^{\circ}$ 09E8, vencimento em novembro/2000. Foi utilizado o protocolo do $\mathrm{Dr}$. Palmquist (1999; comunicação pessoal) para análise em leitor do tipo E.L.I.S.A.

O padrão de $1 \mathrm{mEq} / \mathrm{L}$ de ácido oléico, já incluso no kit, foi diluído com solução salina de maneira a obter concentrações de 0,$125 ; 0,5 ; 0,75$ e 1,0 $\mathrm{mEq} / \mathrm{L}$ que foram então armazenados em tubos tipo "eppendorff" e mantidos refrigerados por até 5 dias.

Cada célula da placa de E.L.I.S.A. continha, ao final do processo de pipetagem, $10 \mu \mathrm{l}$ do branco, padrão ou amostra e mais $40 \mu \mathrm{l}$ de diluente (solução salina), utilizando-se para isto um pipetador/diluidor automático. A própria solução salina foi utilizada como branco.

Ao término desta fase, com a utilizaçăo de uma micropipeta de 8 canais (Sigma Diagnostics, St. Louis, MO, USA) foi adicionado o reagente $A$, na quantidade de $50 \mu l / c e ́ l u l a$. A placa foi em seguida agitada no próprio leitor e posteriormente incubada em uma estufa a $37^{\circ} \mathrm{C}$ por 10 minutos, seguindo-se a adição do reagente $B$, na quantidade de $100 \mu$ l/célula e novamente agitada e incubada, por mesmo tempo e temperatura. Após a última incubação, aguardou-se 3 minutos e procedeu-se a leitura da placa. 
Os padrões e o branco foram utilizados em quadriplicata, possibilitando assim a exclusão de alguma das repetições, a fim de manter um coeficiente de variação baixo para os padrões e evitando também a necessidade de repetição de uma placa inteira em decorrência de problemas na pipetagem. As amostras de plasma foram analisadas em duplicata, assumindo-se um coeficiente de variação máximo de $5 \%$ entre as replicatas. Foi utilizado como controle de qualidade, em triplicata, uma solução de $0,25 \mathrm{mEq} / \mathrm{L}$, constituída a partir do padrão original especificamente para este fim.

As amostras que apresentaram concentrações superiores ao padrão mais elevado, neste caso 1,0 mEq/L, foram diluídas com solução salina (1:1) e analisadas novamente.

\subsubsection{Metodologia para determinação de $\beta$-hba}

As análises de $\beta$-hba e AST foram realizadas no Departamento de Bioquímica Clínica da Faculdade de Medicina Veterinária e Zootecnia, Universidade de São Paulo (FMVZ-USP). A concentração plasmática de $\beta$-hba foi determinada utilizando o kit 310-A UV (Sigma Diagnostics, St. Louis, MO 63178, USA), lote $069 \mathrm{H} 6062$, vencimento em junho/2000, que se baseia no método enzimático descrito por Willianson et al. (1962).

O plasma foi utilizado para análise simultânea de $\beta$-hba e AST com auxílio de um analisador bioquímico automático modelo Technicon RA 100 (Technicon Instruments Co., Tarrytown, NY, USA) , o qual expressa os resultados de concentração plasmática de $\beta$-hba em $\mathrm{mg} / \mathrm{dl}$. As análises foram feitas segundo protocolo fornecido pela Sigma-Aldrich do Brasil para o modelo de analisador bioquímico em questão.

O aparelho foi calibrado com um padrão comercial, de concentração conhecida, $50 \mathrm{mg} / \mathrm{dl}$ ( $\mathrm{n}^{\circ}$ de catálogo 310-50), já incluso no kit 310-A UV. O padrão foi diluído (1:10) com água deionizada bidestilada, a fim de adequar a 
calibração do aparelho aos valores mais baixos encontrados nestas amostras. Amostras com concentrações superiores a $25 \mathrm{mg} / \mathrm{dl}$ foram diluídas (1:1) com solução fisiológica ( $\mathrm{NaCl}$ a $0,9 \%$ ) e analisadas novamente.

O controle de qualidade das reações realizadas foi feito com soros controles comerciais, soro controle normal e elevado $\left(H 2511 n^{\circ}\right.$ e $3511 n^{\circ}$, Sigma Diagnostics, St. Louis, MO 63178, USA), lote $n^{\circ} 079 H 6135$ com vencimento em Julho de 20001.

\subsubsection{Metodologia para determinação de AST}

A determinação da atividade enzimática de AST (aspartato aminotransferase) foi feita com 0 auxílio do mesmo analisador bioquímico descrito acima, o qual expressa os resultados de atividade de AST em unidades internacionais por litro (UI/L). Para este procedimento foi utilizado o kit MR1 (Boehinger Mannhein, BmbH, Germany) lote 60510401, vencimento em janeiro/2001, que se baseia na metodologia cinética otimizada preconizada pela INTERNATIONAL FEDERATION OF CLINICAL CHEMISTRY (IFCC, 1975).

O principio do método é baseado na ação catalítica da enzima AST sobre alfacetoglutarato e o L-aspartato, originando o L-glutamato e oxalacetato. Esta última substância é convertida em L-malato pela ação da malato desidrogenase, sendo que nesta etapa da reação ocorre, simultaneamente, a oxidação de $\mathrm{NADH}$ a $\mathrm{NAD}^{+}$. O NADH tem a capacidade de absorver luz de comprimento de onda de $340 \mathrm{~nm}$, o mesmo não acontecendo com $\mathrm{NAD}^{+}$, logo há uma diminuição na absorção de luz ao longo do processo. A atividade da enzima é medida através da diferença de luz absorvida entre a leitura inicial e a final, aplicando-se a este valor um fator, o qual é gerado através da calibração do equipamento com calibradores de atividade conhecida.

O controle de qualidade foi feito com a utilização de soros controles comerciais (Precinorm U e Precipath U, Roche Diagnostics $\mathrm{GmbH}$, Mannhein, 
Alemanha).

4.5.7 Metodologia de coleta de sangue para determinação de progesterona.

As amostras de sangue para determinação de progesterona (P4) foram colhidas duas vezes por semana, as segundas e quintas-feiras, a partir dos 10 dias de lactação até os 63 dias, no momento em que foi realizado o exame ultrassonográfico. O material utilizado assim como os procedimentos após a coleta foram idênticos aos já descritos anteriormente.

4.5.8 Metodologia para determinação de progesterona plasmática.

A concentração plasmática de progesterona foi determinada no Laboratório de Dosagens Hormonais do Departamento de Reprodução Animal (VRA), Faculdade de Medicina Veterinária e Zootécnica (FMVZ) da Universidade de São Paulo (USP).

As amostras de sangue foram analisadas em duplicata, através da técnica de radioimunoensaio (RIA) utilizando o kit comercial CAC em fase sólida (Progesterone Coat-a-Count, Diagnostics Products Co., Los Angeles, CA, USA), lote TPG1 1168, vencimento em 31 de outubro/2000. Foram utilizados dois controles de qualidade, os padrões do kit nas concentrações de $0,1 \mathrm{ng} / \mathrm{ml}$ e $20 \mathrm{ng} / \mathrm{ml}$, em duplicata, ao início e fim de cada ensaio. $O$ coeficiente de variação médio dentro de ensaio foi $4,72 \%$ e de $5,87 \%$ entre os ensaios.

4.5.9 Metodologia de coleta de dados e cálculo das taxas de incidência de patologias

Os resultados de incidência para as diferentes patologias avaliadas foram calculados para cada tratamento, considerando-se as vacas positivas sobre o total de vacas avaliadas em cada tratamento (quinze 
vacas/tratamento). 0 número total de vacas para o tratamento controle foi de quatorze vacas mais uma parcela perdida.

Os resultados de mastite clínica foram calculados levando em consideração a população de vacas e a população de quartos mamários em cada tratamento.

\subsubsection{Distúrbios Metabólicos}

Os registros referentes à incidência de cetose clínica, hipocalcemia clínica e deslocamento de abomaso foram baseados na sintomatologia e exame clínicos dos animais. Diariamente, pela manhã ou tarde, as vacas eram observadas e quando necessário, examinadas a fim de estabelecer um diagnóstico adequado.

A incidência de cetose subclínica foi determinada a partir das concentrações plasmáticas de $\beta$-hba, segundo Lago (1997), considerando positivas, vacas com concentrações superiores ou iguais a $10 \mathrm{mg} / \mathrm{dl}$.

\subsubsection{Parâmetros reprodutivos}

O diagnóstico de retenção de placenta foi feito segundo Paisley et al. (1986), considerando positivas, vacas que retiveram as membranas fetais por um período superior a 24 horas. O diagnóstico de metrite foi baseado no exame clínico do animal. Vacas com conteúdo atípico (sanguinolento a purulento, mal cheiroso) e algumas vezes com evolução do quadro, apresentando comprometimento sistêmico (aumento de temperatura corporal) foram consideradas positivas. As vacas só receberam tratamento para metrite em caso de aumento de temperatura corporal, medida no período da manhã. $O$ tratamento consistiu unicamente da aplicação de antibiótico parenteral, não sendo utilizado qualquer tipo de terapia hormonal associada a este.

As concentrações médias de progesterona ao longo das nove primeiras 
semanas de lactação foram calculadas a partir de amostras de sangue de vacas que não apresentaram cisto ovariano e corpo lúteo persistente, com concentrações superiores a $0,5 \mathrm{ng} / \mathrm{ml}$. Neste resultado estão incluídas, portanto, vacas que apresentaram ciclo estral curto e concentrações de progesterona de um terceiro ciclo estral, quando presente. Os resultados segmentados por ciclo estral, não incluíram as vacas com cisto ovariano, corpo lúteo persistente e ciclo estral curto, para nenhum dos tratamentos.

Para análise de regressão, não foram utilizadas amostras provenientes de vacas com cisto ovariano ou que apresentavam corpo lúteo persistente.

\subsubsection{Mastite}

Diariamente, durante a ordenha da manhã e da tarde as vacas tiveram os primeiros jatos avaliados em caneca de fundo escuro e os casos de mastite clínica, assim como os tratamentos, foram registrados para todos os animais. As vacas positivas para o teste da caneca foram classificadas, por quarto mamário, conforme esquema abaixo:

1. leite normal e quarto mamário normal ;

2. quarto normal e leite suspeito;

3. quarto normal e leite alterado (grumos evidentes);

4. quarto e leite alterados (coloração, consistência e temperatura);

5. quarto e leite alterados, com comprometimento sistêmico da vaca (aumento de temperatura corpórea).

Portanto, animais que não apresentaram sinais clínicos de mastite durante o experimento receberam escore 1 . Aquelas vacas que apresentaram evolução no escore de mastite clínica em um mesmo quarto foram classificadas segundo o maior escore atribuído. Um mesmo quarto foi contabilizado como positivo apenas uma vez, sendo excluído da contagem futura, caracterizando 
então os resultados como incidência de mastite clínica.

\subsubsection{Pesagem e amostragem de leite}

A produção de leite foi registrada diariamente, na ordenha da manhã e tarde. As amostras para composição do leite foram colhidas, manhã e tarde, a cada 7 dias até a nona semana de lactação e analisadas para determinação de gordura, proteína, lactose, sólidos totais e células somáticas no Laboratório de Análise de Leite do Departamento de Produção Animal da ESALQ - USP.

A produção de leite corrigida para $3,5 \%$ de gordura foi calculada a partir da fórmula sugerida por Gravert (1987), como mostrado abaixo.

$$
\operatorname{LCG}(3,5 \%)=(0,4337 \text { * } P)+(16,218 \text { * PG) }
$$

onde,

P: produção de leite $(\mathrm{kg} / \mathrm{dia})$;

PG: produção de gordura ( $\mathrm{kg} / \mathrm{dia})$.

\subsubsection{Avaliação do escore de condição corporal}

A determinação do escore de condição corporal (ECC) foi feita no dia da secagem das vacas (60 dias antes da data prevista para o parto), ao parto e durante a lactação a cada 14 dias $\left(14^{\circ}, 28^{\circ}, 42^{\circ}\right.$ e $56^{\circ}$ dia de lactação). Foi utilizada a metodologia descrita por Edmondson et al. (1989), que classifica os animais quanto ao ECC em escala de 1 a 5 (1=muito magra; $5=$ muito gorda). Com o objetivo de minimizar o efeito subjetivo deste parâmetro, todas as avaliações foram realizadas pela mesma pessoa. 


\subsubsection{Exame ultrassonográfico}

O exame ultrassonográfico do trato reprodutivo foi efetuado em todas as vacas a partir do $10^{\circ}$ dia de lactação, duas vezes por semana, as segundas e quintas-feiras. Foi utilizado um aparelho de ultrassom Pie Medical SCANNER 200 VET equipado com um transdutor de 7,5 $\mathrm{MHz}$.

O exame reprodutivo foi iniciado com palpação retal do útero e localização dos ovários na cavidade abdominal. Foi avaliado o posicionamento, presença de conteúdo, espessura da parede e simetria dos cornos uterinos. A involução uterina foi considerada completa quando evidenciada a ausência de conteúdo uterino, simetria e posicionamento adequado dos cornos uterinos na cavidade pélvica.

Os ovários foram avaliados com o uso do ultrassom para identificação de corpo lúteo, folículos e cistos ovarianos, os quais foram registrados em fichas individuais, semelhante ao descrito por Pierson \& Ginther (1984) e Edmondson et al. (1986). Os folículos foram medidos e registrado o diâmetro de cada folículo. Na presença de corpo lúteo, registrou-se a maior área medida através do ultrassom, sendo que algumas vacas tiveram o mesmo ovário examinado repetidas vezes, a fim de registrar a medida da maneira mais precisa possível, sempre considerando o maior valor. Foram considerados cistos, estruturas com mais de $25 \mathrm{~mm}$, evidenciadas em pelo menos dois exames consecutivos, conforme descrito por Santos, J. (1996).

O início da fase lútea é caracterizado por um aumento crescente nos niveis séricos de progesterona (Stabenfeldt \& Lars-Eric Edqvist, 1988; Derivaux \& Ectors, 1984). Sendo assim, considerou-se o início de uma fase lútea como pelo menos duas amostras de sangue consecutivas com níveis de progesterona crescentes (Eger et al., 1988) e em concordância com os resultados de ultrassom. Assumiu-se como o dia inicial de uma fase lútea, o dia de coleta imediatamente anterior ao que apresentou concentração plasmática 
maior ou igual a $0,5 \mathrm{ng} / \mathrm{ml}$ e níveis crescentes em, pelo menos, mais uma amostra. $O$ ciclo estral foi considerado de curta duração quando apresentou menos que 11 dias (Eger et al., 1988). Foi considerado corpo lúteo persistente, quando observado por um período maior que 25 dias, na mesma localização dos exames anteriores, semelhante ao sugerido por Derivaux \& Ectors (1984). 


\section{RESULTADOS}

As vacas dos tratamentos monensina sódica e propileno glicol, quando ajustadas para a data efetiva do parto, receberam os aditivos a partir de 35,72 $\pm 1,74$ e $20,97 \pm 2,03$ dias antes do parto, respectivamente.

TABELA 7: Produção média de leite ( $\mathrm{kg} / \mathrm{vaca} / \mathrm{dia})$, por semana, para as primeiras nove semanas de lactação.

\begin{tabular}{|c|c|c|c|c|}
\hline \multirow[b]{2}{*}{ Semanas } & \multicolumn{3}{|c|}{ Tratamentos } & \multirow[b]{2}{*}{ Subparcela $^{1}$} \\
\hline & $\mathrm{C}$ & $\mathrm{M}$ & PG & \\
\hline 1 & 27,70 & 26,63 & 25,95 & 26,76 \\
\hline 2 & 30,31 & 28,67 & 27,76 & 28,91 \\
\hline 3 & 30,86 & 29,50 & 29,55 & 29,97 \\
\hline 4 & 31,80 & 31,20 & 31,78 & 31,59 \\
\hline 5 & 32,87 & 33,89 & 33,16 & 33,31 \\
\hline 6 & 32,50 & 33,60 & 33,28 & 33,12 \\
\hline 7 & 31,36 & 33,16 & 33,28 & 32,60 \\
\hline 8 & 31,01 & 33,41 & 32,85 & 32,43 \\
\hline 9 & 31,25 & 34,10 & 32,98 & 32,78 \\
\hline Parcelas $^{2}$ & 31,075 & 31,575 & 31,177 & \\
\hline
\end{tabular}

${ }^{1}$ Subparcela, produção média de todos os tratamentos.

${ }^{2}$ Parcela, produção média por tratamentos.

A duração média do periodo seco foi de $63,01 \pm 2,72 ; 79,01 \pm 17,52$ e $62,08 \pm 2,30$ dias para o controle, monensina sódica e propileno glicol, 
respectivamente, não havendo diferença entre os tratamentos $(P=0,44)$.

Os resultados referentes a produção e composição do leite nas primeiras nove semanas de lactação são apresentados na Tabela 7 e as produções médias de leite, no período experimental total, na Tabela 8. Não houve efeito da utilização de monensina sódica (M) ou propileno glicol (PG) durante o período pré-parto sobre produção de leite ou produção de leite corrigida para $3,5 \%$ de gordura, embora $M$ tenha mostrado uma tendência $(P=0,15)$ de maior produção de leite corrigido para $3,5 \%$ de gordura. As vacas tratadas com monensina sódica apresentarem teores médios de gordura no leite superiores $(P=0,056)$ ao controle e esta tendência permaneceu para produção de gordura, porém com uma probabilidade estatística menor $(P=0,10)$.

TABELA 8: Produção, produção corrigida para 3,5\% de gordura (LCG - 3,5\%) e composição do leite, média das nove primeiras semanas de lactação.

\begin{tabular}{|c|c|c|c|c|c|c|}
\hline \multirow[b]{2}{*}{ Parâmetros } & \multicolumn{3}{|c|}{ Tratamentos } & \multirow[b]{2}{*}{ EPM } & \multicolumn{2}{|c|}{$\operatorname{Pr}>F^{2}$} \\
\hline & $\mathrm{C}$ & $\mathbf{M}$ & PG & & $\mathrm{T}$ & $\mathrm{T} v s \mathrm{t}$ \\
\hline Leite, $\mathrm{kg} / \mathrm{v} / \mathrm{d}$ & 31,07 & 31,57 & 31,18 & 0,930 & 0,72 & 0,92 \\
\hline $\mathrm{LCG}, \mathrm{kg} / \mathrm{v} / \mathrm{d}$ & 29,93 & 31,27 & 30,36 & 0,958 & 0,15 & 0,57 \\
\hline Gordura, $\%^{1}$ & $3,27^{b}$ & $3,46^{\mathrm{a}}$ & $3,37^{\mathrm{ab}}$ & 0,078 & 0,056 & 0,83 \\
\hline Gordura, $\mathrm{g} / \mathrm{v} / \mathrm{d}^{1}$ & $1.016,56^{b}$ & $1.083,65^{\mathrm{a}}$ & $1.039,43^{\mathrm{ab}}$ & 86,69 & 0,10 & 0,45 \\
\hline Proteína, \% & $3,02^{\mathrm{a}}$ & $2,92^{b}$ & $3,02^{a}$ & 0,029 & 0,0006 & 0,99 \\
\hline Proteína, g/v/d & 935,50 & 914,82 & 923,36 & 14,57 & 0,56 & 0,86 \\
\hline $\mathrm{EST}^{3}, \%$ & 11,77 & 11,77 & 11,72 & 0,085 & 0,87 & 0,96 \\
\hline EST, g/v/d & $3.652,51$ & $3.696,23$ & $3.621,28$ & 61,23 & 0,60 & 0,63 \\
\hline Lactose, $\%$ & $4,72^{\mathrm{a}}$ & $4,63^{b}$ & $4,60^{b}$ & 0,085 & 0,0006 & 0,94 \\
\hline
\end{tabular}

Letras minúsculas diferentes na mesma linha, diferem estatisticamente.

${ }^{1}$ Valores de significância baseados em dados transformados, respectivamente (log 10 e raiz quadrada).

${ }^{2}$ Valor de significância para efeito de tratamento $(T)$ e interação tratamento $x$ tempo $(T v s t)$.

${ }^{3}$ EST: Extrato seco total.

O teor médio de proteína do leite nas primeiras nove semanas de lactação foi menor $(P<0,01)$ para vacas que receberam monensina sódica, 
porém não houve diferença para a produção média de proteína. As vacas que receberam M ou PG apresentaram teores médios de lactose no leite inferiores ao controle $(P<0,01)$. Não houve diferença nos teores de extrato seco total (EST) e na produção deste constituinte do leite nas primeiras nove semanas de lactação.

As coletas de sangue durante o período pré-parto foram baseadas na data prevista para o parto, portanto nem sempre corresponderam ao dia proposto. Após serem ajustadas para a data efetiva do parto, os dias médios das amostras utilizadas para determinação dos parâmetros sanguíneos não diferiram $(P=0,95)$ entre os tratamentos, como é mostrado na Tabela 9. A pequena variação observada para as amostras coletadas no período pós-parto foi decorrente de algumas coletas terem sido refeitas no dia seguinte, por motivos de quebra de tubos ou baixa qualidade (em geral, alta hemólise do plasma após centrifugação).

TABELA 9: Dias médios, em relação ao dia do parto, das amostras utilizadas para análise de glicose, insulina, AGL e $\beta$-hba.

\begin{tabular}{|c|c|c|c|c|}
\hline \multicolumn{5}{|c|}{ Dias médios } \\
\hline Tempo & $\mathrm{C}^{1}$ & $\mathrm{M}^{1}$ & $\mathrm{PG}^{1}$ & EPM \\
\hline-35 & $-33,80$ & $-36,46$ & $-35,20$ & 1,72 \\
\hline-21 & $-20,28$ & $-21,24$ & $-20,65$ & 0,35 \\
\hline-14 & $-13,36$ & $-14,29$ & $-14,18$ & 0,45 \\
\hline-7 & $-6,70$ & $-7,46$ & $-6,00$ & 0,45 \\
\hline-3 & $-2,86$ & $-3,45$ & $-2,37$ & 0,32 \\
\hline 0 & 0 & 0 & $\mathbf{0}$ & 0 \\
\hline 7 & 6,98 & 7,06 & 7,13 & 0,05 \\
\hline 14 & 13,62 & 14,00 & 14,13 & 0,14 \\
\hline 21 & 20,98 & 21,00 & 21,06 & 0,02 \\
\hline
\end{tabular}

${ }^{1}$ Não houve efeito significativo da interação T vs $t, p=0,95$. 
Para as análises dos parâmetros sanguíneos, à exceção de progesterona, as amostras coletadas aos 35 dias antes da data prevista para 0 parto foram utilizadas como covariável, uma vez que, teoricamente, durante esta fase o animal ainda não apresentaria alterações fisiológicas nas concentrações dos parâmetros sanguíneos avaliados decorrentes da proximidade ao parto e dos tratamentos aplicados.

Não houve diferença significativa entre os tratamentos nas concentrações plasmáticas dos quatro parâmetros avaliados para as amostras utilizadas como covariável (Tabela 10). As concentrações de AST no entanto, apresentaram leve tendência $(P=0,16)$, sendo ligeiramente superiores para as vacas que receberam $M$ e $P G$ aos -35 dias. Os dados referentes às concentrações médias dos parâmetros sanguíneos analisados encontram-se na Tabela 11.

TABELA 10: Valores médios utilizados como covariável (-35dias), conforme o parâmetro sanguíneo e o tratamento.

\begin{tabular}{lrrrrrr} 
& \multicolumn{3}{c}{ Tratamentos } & & Pr $>F^{1}$ \\
\cline { 2 - 4 } Parâmetro & \multicolumn{1}{c}{ C } & \multicolumn{1}{c}{ M } & \multicolumn{1}{c}{ PG } & EPM & \multicolumn{1}{c}{ T } \\
\hline Glicose $(\mathrm{mg} / \mathrm{dl})$ & 64,16 & 61,09 & 64,39 & 1,80 & 0,23 \\
AGL $(\mu \mathrm{mol} / \mathrm{L})$ & 258,88 & 331,66 & 282,06 & 55,43 & 0,64 \\
$\beta-h b a(\mathrm{mg} / \mathrm{dl})$ & 3,36 & 3,97 & 4,04 & 0,30 & 0,21 \\
Insulina $(\mu \mathrm{U} / \mathrm{ml})$ & 11,34 & 10,26 & 11,03 & 1,06 & 0,75 \\
AST $(\mathrm{U} / \mathrm{L})$ & 20,05 & 22,53 & 22,73 & 1,10 & 0,16
\end{tabular}

'Valor de significância para efeito de tratamento $(\mathrm{T})$.

Houve efeito de tratamento sobre as concentrações plasmáticas de glicose, porém este efeito foi dependente do dia de coleta. Os valores médios de glicose, segundo o dia de coleta, são mostrados na Tabela 12. As vacas que receberam PG apresentaram concentrações de glicose numericamente superiores aos demais durante todo periodo pré-parto, porém esta diferença foi 
TABELA 11: Concentrações plasmáticas médias para os diferentes parâmetros sanguíneos analisados.

\begin{tabular}{|c|c|c|c|c|c|c|}
\hline \multirow[b]{2}{*}{ Parâmetro } & \multicolumn{3}{|c|}{ Tratamentos } & \multirow[t]{2}{*}{ EPM } & \multicolumn{2}{|c|}{$\operatorname{Pr}>F^{1}$} \\
\hline & $\mathrm{C}$ & $\mathbf{M}$ & $\mathrm{PG}$ & & $\mathrm{T}$ & $\mathrm{T} v s \mathrm{t}$ \\
\hline Glicose (mg/dl) & $63,14^{b}$ & $63,33^{b}$ & $65,39^{\mathrm{a}}$ & 0,93 & 0,09 & 0,013 \\
\hline Insulina $(\mu \mathrm{mol} / \mathrm{ml})^{2}$ & $8,42^{b}$ & $8,99^{b}$ & $10,29^{a}$ & 0,37 & 0,007 & 0,092 \\
\hline $\mathrm{AGL}(\mu \mathrm{mol} / \mathrm{L})^{3}$ & $344,72^{a b}$ & $402,40^{\mathrm{a}}$ & $329,92^{b}$ & 25,26 & 0,009 & 0,61 \\
\hline$\beta-h b a(\mathrm{mg} / \mathrm{dl})^{2}$ & $4,29^{\mathrm{a}}$ & $4,57^{\mathrm{a}}$ & $4,10^{b}$ & 0,19 & 0,026 & 0,034 \\
\hline $\operatorname{AST}(\mathrm{UI} / \mathrm{L})^{2}$ & $23,23^{\mathrm{a}}$ & $23,58^{\mathrm{a}}$ & $21,62^{b}$ & 0,73 & $\mathbf{0 , 0 3 4}$ & 0,67 \\
\hline
\end{tabular}

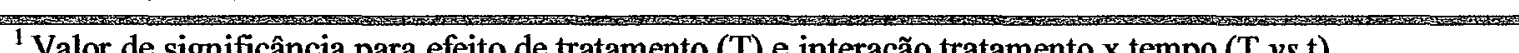

${ }^{1}$ Valor de significância para efeito de tratamento (T) e interação tratamento $\mathrm{x}$ tempo (T vs $\mathrm{t}$ ).

${ }^{2}$ Valores de significância baseados nos dados transformados $(\log 10)$.

${ }^{3}$ Valores de significância baseados nos dados transformados (raiz quadrada).

TABELA 12: Concentrações plasmáticas médias de glicose $(\mathrm{mg} / \mathrm{dl})$ ao longo do período experimental, segundo os dias de coleta.

\begin{tabular}{|c|c|c|c|c|}
\hline \multirow[b]{3}{*}{ Dias } & \multicolumn{3}{|c|}{ Glicose (mg/d) } & \multirow{3}{*}{$\frac{\mathrm{P}=0,0001}{\text { Subparcela }^{1}}$} \\
\hline & \multicolumn{3}{|c|}{ Tratamentos } & \\
\hline & $\mathrm{C}$ & $\mathbf{M}$ & PG & \\
\hline-21 & $64,37^{b}$ & $63,16^{b}$ & $72,48^{a}$ & 66,67 \\
\hline-14 & 63,98 & 63,41 & 67,55 & 64,98 \\
\hline-7 & 67,09 & 65,08 & 69,18 & 67,12 \\
\hline-3 & $61,33^{b}$ & $65,75^{a b}$ & $69,32^{a}$ & 65,47 \\
\hline 0 & $72,22^{a}$ & $65,88^{b}$ & $62,14^{b}$ & 66,75 \\
\hline 7 & 56,83 & 58,34 & 59,28 & 58,15 \\
\hline 14 & 60,11 & 61,08 & 61,36 & 60,85 \\
\hline 21 & 59,23 & 63,98 & 61,83 & 61,68 \\
\hline & & - & & \\
\hline rcelas & $63,14^{\mathrm{B}}$ & $63,33^{B}$ & $65,39^{\mathrm{A}}$ & \\
\hline
\end{tabular}

\footnotetext{
${ }^{1}$ Subparcela, concentração média dos 3 três tratamentos.

${ }^{2}$ Letras minúsculas diferentes na mesma linha, diferem estatisticamente para $p<0,013$ e maiúsculas para $\mathrm{p}<0,09$
}

estatisticamente significativa apenas aos 21 e aos 3 dias antes do parto, 
quando comparado ao tratamento $\mathrm{C}$. $\mathrm{O}$ tratamento $\mathrm{C}$ apresentou concentrações superiores $(P<0,05)$ aos demais ao parto.

TABELA 13: Concentrações plasmáticas médias de insulina $(\mu \mathrm{mol} / \mathrm{ml})$ ao longo do período experimental, segundo os dias de coleta.

\begin{tabular}{|c|c|c|c|c|}
\hline \multirow[b]{3}{*}{ Dias } & \multicolumn{3}{|c|}{ Insulina $(\mu \mathrm{mol} / \mathrm{ml})^{3}$} & \multirow{3}{*}{$\frac{\mathrm{P}=0,0001}{\text { Subparcela }^{1}}$} \\
\hline & \multicolumn{3}{|c|}{ Tratamentos } & \\
\hline & $\mathrm{C}$ & $\mathrm{M}$ & PG & \\
\hline-21 & $10,14^{b}$ & $10,54^{\mathrm{b}}$ & $17,00^{a}$ & 12,56 \\
\hline-14 & $9,39^{b}$ & $11,42^{\mathrm{ab}}$ & $14,11^{\mathrm{a}}$ & 11,94 \\
\hline-7 & 9,73 & 9,88 & 10,66 & 10,09 \\
\hline-3 & $6,21^{\mathrm{ab}}$ & $5,61^{b}$ & $8,04^{\mathrm{a}}$ & 6,62 \\
\hline 0 & 7,62 & 8,68 & 7,81 & 8,04 \\
\hline 7 & 8,13 & 10,08 & 8,93 & 9,05 \\
\hline 14 & 7,83 & 7,91 & 8,12 & 7,95 \\
\hline 21 & 8,30 & 7,76 & 7,67 & 7,91 \\
\hline Parcelas & $8,42^{\mathrm{B}}$ & $8,99^{\mathrm{B}}$ & $10,29^{\mathrm{A}}$ & \\
\hline
\end{tabular}

${ }^{1}$ Subparcela, concentração média dos 3 três tratamentos.

${ }^{2}$ Letras minúsculas diferentes na mesma linha, diferem estatisticamente para $\mathrm{p}<0,09$ e maiúsculas para $\mathrm{p}<0,007$.

${ }^{3}$ Valores de significância baseados nos dados transformados $(\log 10)$.

O tratamento PG apresentou concentrações médias de insulina superiores ao demais ao longo do período avaliado. Os dados de insulina apresentaram tendência para interação tratamento $x$ tempo $(P=0,09)$ conforme mostra Tabela 13. Assim como para glicose, não houve diferenças significativas entre os tratamentos durante o período pós-parto nas concentrações de insulina plasmática. As vacas que receberam PG apresentaram concentrações plasmáticas de insulina superiores aos demais tratamentos durante o pré-parto, apresentando tendência $(P<0,09)$ aos -21 dias. Também apresentou tendência de valores superiores ao C (-14 dias) e ao 
M (-3 dias). Pode-se observar uma diminuição nas diferenças numéricas entre PG e os demais tratamentos, a medida que se aproxima o dia do parto.

As concentraçōes médias de insulina diminuíram em todos os tratamentos a medida que se aproximou o parto, permanecendo semelhantes durante o período de lactação.

TABELA 14: Concentrações plasmáticas médias de ácidos graxos livres (AGL) ao longo do periodo experimental, segundo os dias de coleta.

\begin{tabular}{|c|c|c|c|c|}
\hline \multirow[b]{3}{*}{ Dias } & \multicolumn{3}{|c|}{ AGL $(\mu \mathrm{mol} / \mathrm{L})$} & \multirow{3}{*}{$\frac{\mathrm{P}=0,0001}{\text { Subparcela }^{1}}$} \\
\hline & \multicolumn{3}{|c|}{ Tratamentos $^{2}$} & \\
\hline & $\mathrm{C}$ & $\mathrm{M}$ & PG & \\
\hline-21 & 161,60 & 182,14 & 124,22 & 155,99 \\
\hline-14 & 195,74 & 200,98 & 166,90 & 187,87 \\
\hline-7 & 255,49 & 326,72 & 178,43 & 253,55 \\
\hline-3 & 322,03 & 295,49 & 267,57 & 295,03 \\
\hline 0 & 649,42 & 625,24 & 661,78 & 645,48 \\
\hline 7 & 469,30 & 601,79 & 476,61 & 515,90 \\
\hline 14 & 367,40 & 531,66 & 364,65 & 421,23 \\
\hline 21 & 336,80 & 455,19 & 399,18 & 397,05 \\
\hline Parcelas & $344,72^{\mathrm{AB}}$ & $402,40^{\mathrm{A}}$ & $329,92^{\mathrm{B}}$ & \\
\hline
\end{tabular}

Letras maiúsculas na mesma linha diferem estatisticamente para $\mathrm{p}<0,009$.

${ }^{1}$ Subparcela, concentração média dos 3 três tratamentos.

${ }^{2}$ Valores de significância baseados nos dados transformados (raiz quadrada)

As concentrações plasmáticas de AGL foram menores para o tratamento PG quando comparado a $M$, no entanto não diferiu do controle, nem tão pouco houve efeito significativo da interação tratamento $x$ tempo para esta variável (Tabela 14 e Figura 3).

As concentrações plasmáticas médias de $\beta$-hba foram inferiores para PG, no entanto este resultado foi significativamente dependente do tempo (dia de coleta), conforme os dados apresentados na Tabela 15 e Figura 3. 
TABELA 15: Concentrações plasmáticas médias de $\beta$-hidroxibutirato ( $\beta$-hba) ao longo do periodo experimental, segundo os dias de coleta.

\begin{tabular}{|c|c|c|c|c|}
\hline \multicolumn{5}{|c|}{$\beta-h b a(m g / d l)$} \\
\hline \multirow[b]{2}{*}{ Dias } & \multicolumn{3}{|c|}{ Tratamentos } & \multirow{2}{*}{$\mathrm{P}=0,0001$} \\
\hline & $\mathrm{C}$ & $\mathrm{M}$ & PG & \\
\hline-21 & 3,25 & 3,38 & 3,15 & 3,26 \\
\hline-14 & $3,81^{\mathrm{a}}$ & $3,43^{\mathrm{a}}$ & $2,66^{b}$ & 3,30 \\
\hline-7 & $3,60^{\mathrm{a}}$ & $3,43^{\mathrm{a}}$ & $2,72^{b}$ & 3,25 \\
\hline-3 & $3,88^{\mathrm{a}}$ & $4,55^{\mathrm{a}}$ & $2,68^{b}$ & 3,70 \\
\hline 0 & 4,81 & 5,62 & 4,84 & 5,09 \\
\hline 7 & 5,25 & 5,80 & 6,17 & 5,74 \\
\hline 14 & $4,57^{\mathrm{b}}$ & $5,74^{\mathrm{a}}$ & $5,57^{\mathrm{ab}}$ & 5,29 \\
\hline 21 & 5,16 & 4,62 & 4,97 & 4,92 \\
\hline Parcelas & $4,29^{\mathrm{A}}$ & $4,57^{\mathrm{A}}$ & $4,10^{B}$ & \\
\hline
\end{tabular}

Letras minúsculas na mesma linha diferem estatisticamente para $p<0,034$ e maiúsculas para $p<0,026$.

${ }^{1}$ Subparcela, concentração média dos 3 três tratamentos.

TABELA 16: Incidência de cetose subclínica ( $\beta$-hba $\geq 10 \mathrm{mg} / \mathrm{dl}$ ) durante as primeiras 9 semanas de lactação.

\begin{tabular}{lcccc} 
& & Tratamentos & & Pr $>$ F \\
\cline { 2 - 5 } & $\mathrm{C}$ & $\mathrm{M}$ & $\mathrm{PG}$ & \\
\hline$\%$ & 16,27 & 31,08 & 13,33 & 0,51 \\
$\mathrm{P} / \mathrm{T}(\mathrm{n})^{1}$ & $2 / 14$ & $4 / 14$ & $2 / 15$ & -1 \\
\hline
\end{tabular}

${ }^{1}$ Númerò de animais positivos sobre o total avaliado.

À exceção do $21^{\circ}$ dia pré-parto, as vacas do grupo PG apresentaram concentrações de $\beta$-hba inferiores $(P<0,05)$ aos demais tratamentos durante todo o período pré-parto, periodo este, em que foi fornecido o produto. Ao parto e durante as três primeiras semanas de lactação, houve aumento nas 
concentrações plasmáticas de $\beta$-hba para todos os tratamentos quando comparado ao período pré-parto e, aos 14 dias de lactação, o grupo C apresentou níveis mais baixos $(P<0,05)$ que $M$.

FIGURA 3: Níveis plasmáticos de AGL (- - ) e $\beta$-hba (- -- -) ao longo do período experimental para o tratamento controle, monensina sódica e propileno glicol.

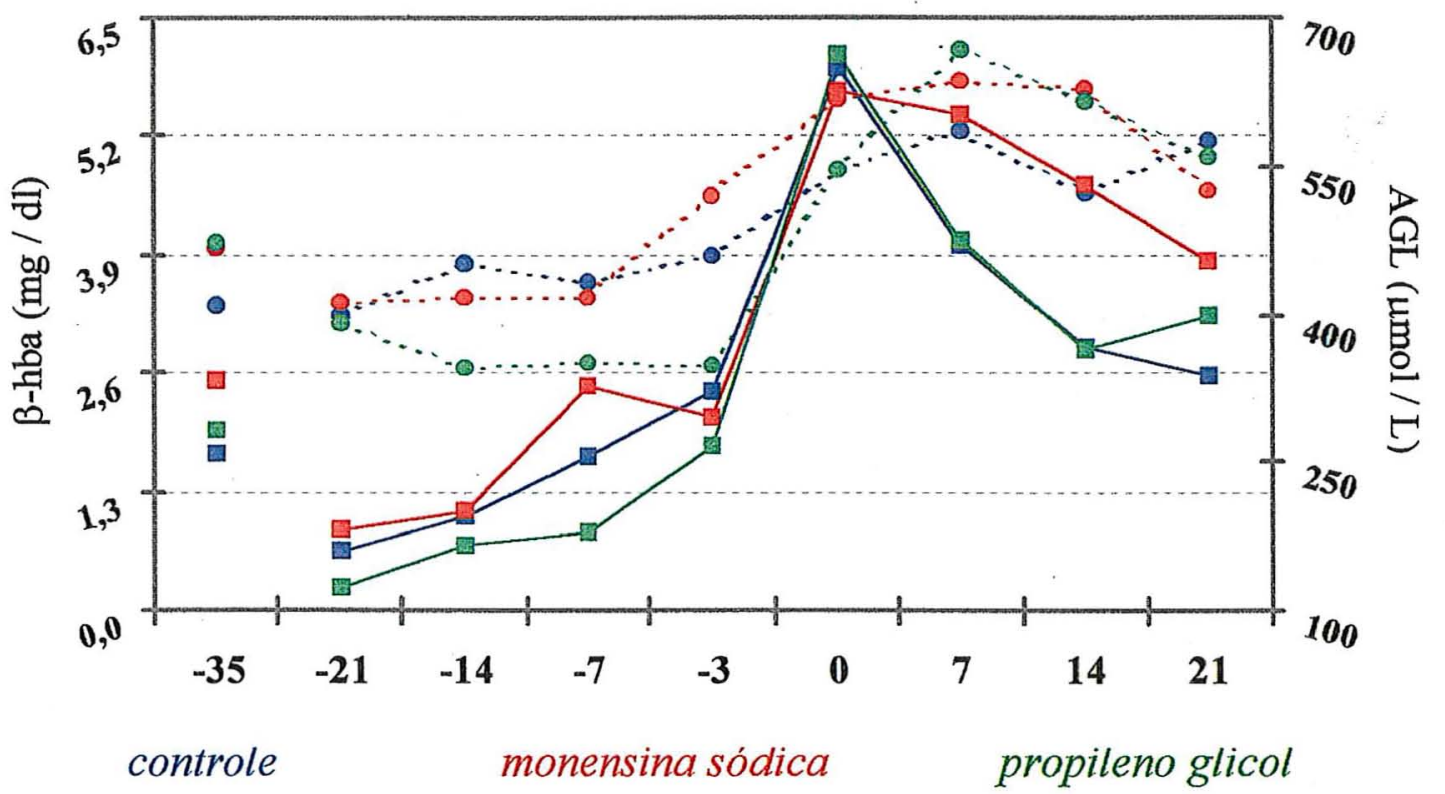

Os resultados de hipocalcemia e deslocamento de abomaso estão de acordo com os registros da fazenda experimental em anos anteriores, não tendo sido observado nenhum caso durante o período experimental, caracterizando um rebanho de baixa incidência destas duas patologias.

Conforme os dados da Tabela 16, não houve efeito significativo de tratamento sobre a incidência de cetose subclínica. Foram considerados como positivas para cetose subclínica, vacas com concentração plasmática de $\beta$-hba superior ou igual a $10 \mathrm{mg} / \mathrm{dl}$.

A Figura 4 mostra a variação de ECC médio para os três tratamentos, mostrando a semelhança no momento da secagem, 60 dias antes da data 
prevista para o parto. Não houve efeito significativo de tratamento, tão pouco efeito da interação tratamento $x$ tempo. Os valores médios mais baixos de ECC obtidos durante esta avaliação foram 3,13; 2,95 e 2,97; para os tratamentos $P G, M$ e $C$, respectivamente. Enquanto os tratamentos $P G$ e $C$ já apresentavam recuperação no ECC a partir dos 42 dias pós-parto, $M$ apresentou perda de ECC médio ao longo dos 56 dias pós-parto.

FIGURA 4: Variação de $\operatorname{ECC}^{1}$ ao longo do período experimental para o tratamento controle (一圆—), monensina (-०—) e propileno glicol (- - -).

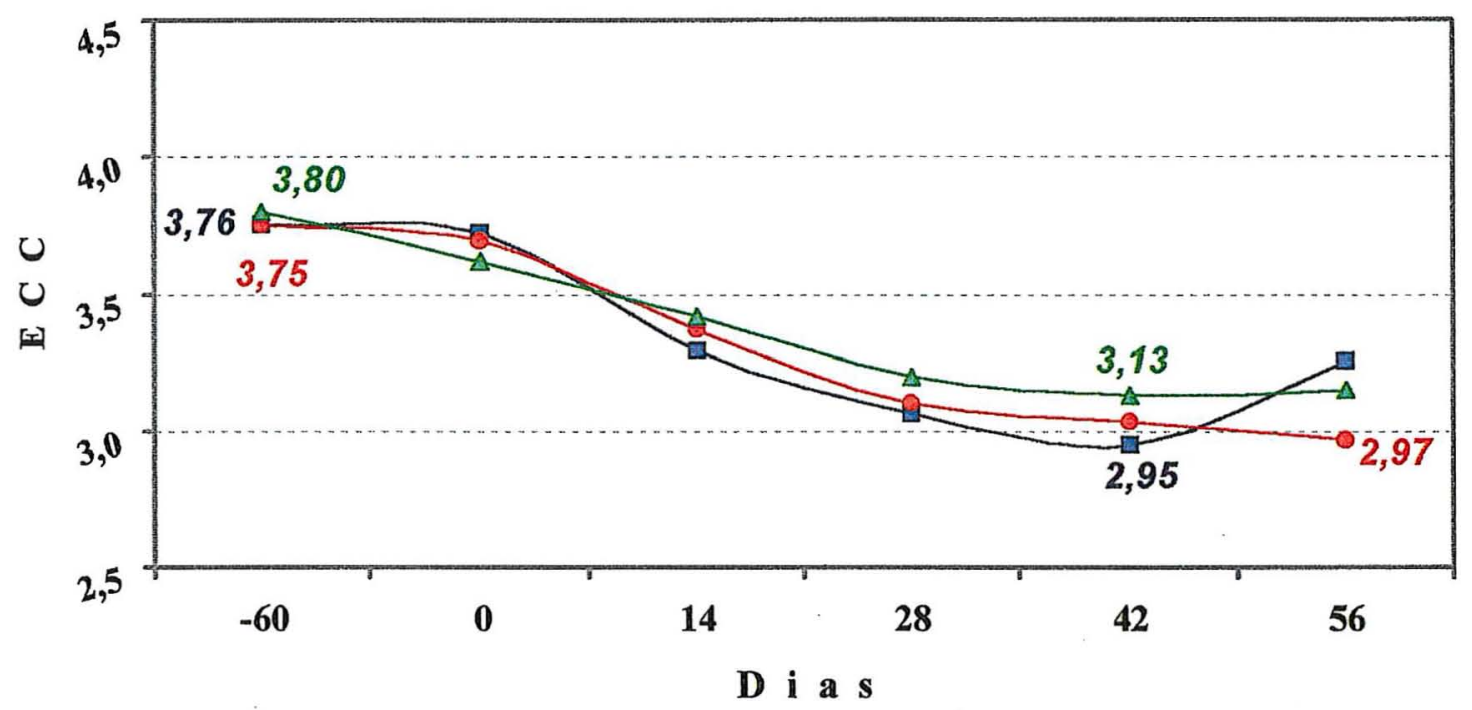

${ }^{1}$ Não houve efeito de tratamento $(\mathrm{p}=0,30)$ e interação $\mathrm{T}$ vs $\mathrm{t}(\mathrm{p}=0,84)$. Os valores de significância foram obtidos com dados transformados (1/raiz quadrada).

Os dados referentes à incidência de distúrbios reprodutivos e dinâmica ovariana são apresentados na Tabela 17. Não houve efeito significativo sobre nenhum dos parâmetros avaliados, porém é importante ressaltar que este tipo de experimento não é o mais adequado para avaliação reprodutiva, onde se faz necessário um grande número de animais avaliados. Portanto, devido ao baixo poder estatístico, algumas diferenças numéricas serão ressaltadas. 
TABELA 17: Incidência de retenção de placenta (RP), metrite, anestro, cisto ovariano, corpo lúteo persistente, tempo para involução uterina (Inv $U$ ), dias para primeira ovulação e número de ciclos estrais curtos ao longo das nove primeiras semanas de lactação.

\begin{tabular}{|c|c|c|c|c|c|}
\hline & \multicolumn{3}{|c|}{ Tratamentos $^{1}$} & \multirow[b]{2}{*}{ EPM } & \multirow[t]{2}{*}{$\operatorname{Pr}>\mathrm{F}$} \\
\hline & $\mathrm{C}$ & $\mathbf{M}$ & PG & & \\
\hline $\mathrm{RP}, \%$ & $20,00(3 / 14)$ & $13,33(2 / 15)$ & $26,66(4 / 15)$ & $\cdots$ & 0,71 \\
\hline Metrite, \% & $47,38(7 / 14)$ & $33,33(5 / 15)$ & $40,00(6 / 15)$ & ---- & 0,79 \\
\hline tratamento, $\%^{2}$ & $7,12(1 / 14)$ & $13,33(2 / 15)$ & $26,66(4 / 15)$ & ---- & 0,35 \\
\hline Inv $\mathrm{U}$, dias & 53,83 & 44,76 & 48,44 & 4,05 & 0,27 \\
\hline Anestro, \% & $14,23(2 / 14)$ & $23,00(3 / 13)$ & $6,66(1 / 15)$ & --- & 0,48 \\
\hline $1^{a}$ ovulação, dias & $18,65(10)$ & $23,37(08)$ & $22,22(13)$ & 2,72 & 0,57 \\
\hline Ciclo estral curto, $\%$ & $20,00(3 / 14)$ & $13,33(2 / 15)$ & $26,66(4 / 15)$ & $-\cdots$ & 0,68 \\
\hline $\mathrm{CL}^{3}$ persistente, $\%$ & $7,14(1 / 14)$ & $6,66(1 / 15)$ & $6,66(1 / 15)$ & ---- & 0,99 \\
\hline Cisto ovariano, \% & $14,28(2 / 14)$ & $20,00(3 / 15)$ & $6,66(1 / 15)$ & ---- & 0,57 \\
\hline
\end{tabular}

${ }^{1}$ Dados entre parêntese representam o número de animais avaliados ou positivos sobre o total avaliado.

${ }^{2}$ Casos de metrite que necessitaram tratamento.

${ }^{3}$ Corpo lúteo.

A incidência de retenção de placenta (RP) foi mais alta do que os 8 a $12 \%$ descritos por Youngquist (1994) para todos os tratamentos, sobretudo para PG $(26,66 \%)$. A incidência de metrite foi alta para todos os tratamentos, no entanto os tratamentos PG e $M$ apresentaram metrites mais severas, necessitando de terapia antibiótica em $66,66 \%(4 / 6)$ e $40 \%(2 / 5)$ dos casos respectivamente, enquanto que o $\mathrm{C}$ em apenas $14,28 \%$ (1/7). $A$ incidência de cistos foliculares e vacas em anestro foi, numericamente maior para $M$ em relação aos demais, sobretudo em relação a PG, que apresentou o menor percentual para estes dois parâmetros.

As concentrações plasmáticas de progesterona são mostradas na Tabela 18, não havendo efeito de tratamento sobre as concentrações médias ao longo das nove primeiras semanas de lactação. $O$ nível médio de progesterona plasmática foi ainda analisado segundo o ciclo estral, primeiro e 
segundo.

TABELA 18: Níveis plasmáticos médios de progesterona $(\mathrm{ng} / \mathrm{ml})$ ao longo das 9 primeiras semanas de lactação, primeiro e segundo ciclos estrais.

\begin{tabular}{|c|c|c|c|c|c|}
\hline \multicolumn{6}{|c|}{ Progesterona (ng/ml) } \\
\hline \multirow[t]{2}{*}{ Fase } & \multicolumn{3}{|c|}{ Tratamentos } & \multirow[b]{2}{*}{ EPM } & \multirow[t]{2}{*}{$\operatorname{Pr}>F$} \\
\hline & $\mathrm{C}$ & $\mathrm{M}$ & PG & & \\
\hline 9 sem. de lactação ${ }^{1}$ & 3,48 & 3,14 & 3,57 & 0,22 & 0,23 \\
\hline Primeiro ciclo estral & $2,73^{b}$ & $3,00^{\mathrm{ab}}$ & $3,50^{\mathrm{a}}$ & 0,34 & $0,0062^{*}$ \\
\hline Segundo ciclo estral & $3,74^{\mathrm{a}}$ & $3,17^{\mathrm{ab}}$ & $3,03^{b}$ & 0,31 & $0,0062^{*}$ \\
\hline
\end{tabular}

No primeiro ciclo estral as vacas do tratamento $P G$ apresentaram níveis médios superiores ao tratamento controle, ocorrendo exatamente o contrário no segundo ciclo estral, onde as vacas do $C$ apresentaram níveis médios superiores a PG.

Os resultados de área de corpo lúteo foram correlacionados por meio de regressão com os níveis plasmáticos de progesterona, incluindo (1) ou não (2) $o$ efeito de dia do ciclo estral, conforme mostram as equações abaixo. 0
1) $Y=-0,00987+0,514 X+0,101 Z$
$\left(R^{2}=0,45\right)$
2) $Y=0,274+0,724 X$
$\left(R^{2}=0,32\right)$

onde,
Y: nível de progesterona plasmática;
$\mathrm{X}$ : área do corpo lúteo $(\mathrm{cm})$;
$Z$ : dia do ciclo estral.

coeficiente de determinação foi maior quando se incluiu na regressão o efeito 
de dia do ciclo estral, embora ambas tenham sido altamente significativas $(P<0,01)$.

A contagem de células somáticas do leite não teve efeito significativo para a interação tratamento $x$ tempo, no entanto as contagens médias ao longo das nove semanas de lactação foram maiores para o tratamento controle que para os demais. Não houve efeito dos tratamentos na incidência de mastite clínica quando se utilizou como população total o número de vacas, no entanto, - tratamento PG apresentou incidência menor quando os dados foram baseados no número de quartos mamários totais por tratamento (Tabela 19).

TABELA 19: Incidência de mastite clínica utilizando como unidade experimental a vaca ou um quarto mamário, escore médio de mastite clínica e contagem de células somáticas (CCS) no leite.

\begin{tabular}{|c|c|c|c|c|c|}
\hline \multirow[t]{2}{*}{ Mastite } & \multicolumn{3}{|c|}{ Tratamentos $^{1}$} & \multirow{2}{*}{\multicolumn{2}{|c|}{$\operatorname{Pr}>F$}} \\
\hline & $\mathrm{C}$ & M & PG & & \\
\hline \multicolumn{6}{|l|}{ Incidência } \\
\hline Animais, \% & $46,20(7 / 14)$ & $60,00(9 / 15)$ & $46,66(7 / 15)$ & ---- & 0,66 \\
\hline Quartos, \% & $32,08(19 / 56)^{a}$ & $35,00(21 / 60)^{a}$ & $16,66(10 / 60)^{b}$ & --- & 0,042 \\
\hline Escore médio $^{3}$ & $1,58^{a}$ & $1,57^{a}$ & $1,20^{\mathrm{b}}$ & 0,099 & 0,0047 \\
\hline $\mathrm{CCS}$, células $/ \mathrm{ml}^{2}$ & $601,95^{\mathrm{a}}$ & $506,17^{b}$ & $335,40^{\mathrm{b}}$ & 88,09 & 0,000 \\
\hline \multicolumn{6}{|c|}{$\begin{array}{l}1{ }^{1} \text { Dados entre parêntese representam o número de animais. } \\
{ }^{2} \text { Contagem de células somáticas }(x 1.000) \text {, significância baseada em dados transformados }(\log 10) \text {. } \\
{ }^{3} \text { Escore de mastite clínica: escore } 1=\text { leite normal; escore } 5=\text { leite e quarto mamário alterados, com } \\
\text { sintoma de comprometimento sistêmico (temperatura corpórea). }\end{array}$} \\
\hline \multicolumn{6}{|c|}{$\begin{array}{l}\text { O escore médio de mastite clínica acompanhou os resultados de } \\
\text { incidência de mastite clínica (baseado em quartos mamários totais), sendo } \\
\text { menor para as vacas que receberam PG. Na Tabela } 20 \text {, os quartos mamários } \\
\text { foram segmentados por faixa de escore de mastite clínica, conforme os } \\
\text { tratamentos. O tratamento PG apresentou tendência para um maior número de } \\
\text { quartos classificados como escore } 1 \text { (leite normal ao teste da caneca de fundo }\end{array}$} \\
\hline
\end{tabular}


(quarto normal e leite com grumos), quando comparado ao tratamento $\mathrm{M}$.

TABELA 20: Distribuição dos quartos mamários (\%) por tratamento, segundo o escore de mastite clínica.

\begin{tabular}{|c|c|c|c|}
\hline \multirow[t]{2}{*}{ Níveis de Escore } & \multicolumn{3}{|c|}{ Tratamentos $^{1}$} \\
\hline & $\mathrm{C}$ & $\mathrm{M}$ & $P G$ \\
\hline Escore 1 (leite normal) & $66,07^{b}$ & $65,00^{b}$ & $83,33^{a}$ \\
\hline Escore 2 & 14,29 & 13,33 & 13,33 \\
\hline Escore 3 & $12,50^{\mathrm{ab}}$ & $21,67^{\mathrm{a}}$ & $3,33^{b}$ \\
\hline Escore 4 & 7,14 & 0 & 0 \\
\hline Escore 5 & 0 & 0 & 0 \\
\hline
\end{tabular}




\section{DISCUSSÃO DOS RESULTADOS}

\subsection{Produção e composição do leite}

Os resultados encontrados neste trabalho referentes a produção de leite, original ou corrigida (Tabelas 7 e 8), estão de acordo com os resultados de outros autores (Fisher et al., 1973) avaliando número semelhante de animais (Birchen et al., 2000; Formigoni et al., 1996; Studer et al., 1993), os quais não encontraram diferença significativa para produção de leite em vacas recebendo propileno glicol (PG), embora apenas Studer et al. (1993) tenham fornecido o produto exclusivamente durante o período pré-parto, como foi o caso neste trabalho. Laranja da Fonseca et al. (1999) observaram maior produção de leite apenas na quarta e quinta semana de lactação para vacas que receberam $P G$, antes e após o parto. $O$ mesmo padrão de resposta foi encontrado em alguns trabalhos para produção de leite em vacas recebendo monensina sódica $(M)$ a partir do período pré-parto (Green et al., 1999; Thomas et al., 1993) ou durante a lactação (Gama, 2000; Abe et al., 1994), as quais foram comparadas a um tratamento controle que não recebeu monensina sódica em fase alguma, diferente do protocolo utilizado neste experimento.

Por outro lado, a suplementação com monensina sódica têm mostrado aumentos de produção de leite da ordem de 0,75 a $2,8 \mathrm{~kg} / \mathrm{vaca} / \mathrm{dia}$, em rebanhos com produções médias entre 28 e 36 litros de leite/vaca (Duffield et al., 1999; Beckett et al.; 1998; Phipps et al.; 1995). Duffield et al. (1999) 
observaram aumento de produção de leite apenas para vacas com ECC acima de 3,25 e uma resposta de $2,5 \mathrm{~kg} / \mathrm{vaca} /$ dia para vacas com ECC superior a 4,0 ao parto. Os resultados de Duffield et al. (1999), sobretudo, suportam o que vem sendo mostrado também por outros autores (Formigoni et al., 1996; Sauer et al. 1973), ou seja, que o potencial beneficio destes aditivos expressar-se-ia de forma mais consistente em situações de risco, como é o caso de vacas com condição corporal excessiva. Duffield et al. (1999) observaram efeito significativo para produção de leite projetada para 305 dias em rebanhos com maior risco de ocorrência de cetose.

É importante considerar que os trabalhos que mostraram efeito sobre produção de leite para vacas tratadas com monensina sódica, avaliaram um grande número de animais (Duffield et al., 1999; Beckett et al.; 1998), em torno de 1000 , enquanto que os trabalhos com propileno glicol, avaliaram não mais que 120 animais (Fisher et al., 1973), o que, nestes casos, pode ter comprometido o poder estatístico dos experimentos (Duffield et al., 1999).

Os resultados de análise bromatológica, presentes na Tabela 2 , mostram que as dietas apresentaram densidade nutricional próxima aos padrões para qual foram balanceadas. A dieta total fornecida durante o período pré-parto apresentou concentrações de $E L_{L}$ e $P B$ superior ao sugerido pelo NRC (1989), porém de acordo com as recomendações mais recentes de pesquisadores da área (Hutjens, 1996; Grummer, 1995). Portanto, é possível afirmar, baseado nos ECC médios (Figura 4) e na composição nutricional das dietas oferecidas, que as vacas encontravam-se em uma situação de baixo risco à ocorrência de distúrbios metabólicos, o que, em parte, explicaria a semelhança nos resultados.

Para o tratamento PG, os dados de proteína no leite estão de acordo com os trabalhos consultados que avaliaram composição do leite, onde nenhum mostrou efeito da utilização deste aditivo sobre percentual ou produção de proteína no leite (Birchen et al., 2000; Formigoni et al., 1996; 
Studer et al., 1993, Fisher et al., 1973). Os resultados de experimentos metabólicos têm mostrado redução na proteólise ruminal e aumento na retenção de nitrogênio (Russell, 1997; Schelling, 1984) em animais recebendo monensina sódica, sugerindo um potencial beneficio sobre proteína do leite (Beckett et al., 1998). Entretanto, os resultados de experimentos de produção muitas vezes não mostram este tipo de resposta (Duffield et al, 1999; Beckett et al., 1998; Abe et al., 1994; Sauer et al., 1989). Lean et al. (1994) observaram efeito significativo sobre produção de proteina do leite em vacas sob pastejo que receberam o tratamento logo após o parto, porém este efeito ocorreu em apenas um dos 6 rebanhos avaliados, o qual também apresentou efeito sobre produção de leite, conforme a tendência observada por Beckett et al. (1998).

Portanto, as respostas encontradas em produção de proteína do leite em vacas recebendo $M$, parecem estar mais relacionadas a um efeito positivo sobre produção de leite do que propriamente um efeito direto sobre o teor protéico do leite (Beckett et al. 1998; Lean et al., 1994).

Para o tratamento $M$, o menor percentual de proteína do leite observado não está de acordo com a maioria dos resultados publicados, embora Phipps et al. (1995) também tenham encontrado resultado semelhante em vacas tratadas durante a lactação. É importante quando se confrontam os dados deste experimento com os presentes na literatura, levar em consideração a realidade particular desta avaliação, onde todas vacas estiveram sob o efeito da monensina sódica durante a lactação.

O tratamento monensina sódica, ao contrário de outros trabalhos (Duffield et al., 1998b; Stephenson et al., 1997; Abe et al., 1994; Thomas et al., 1993; Sauer et al. 1989), apresentou o dobro de vacas positivas para cetose subclínica ( $n=4)$, não diferindo estatisticamente, e concentrações plasmáticas médias de $\beta$-bhba significativamente superiores apenas ao tratamento PG, porém valores numéricos mais elevados na maioria dos dias avaliados. É provável que esta situação metabólica de maior dreno de glicose possa ter 
comprometido a disponibilidade de aminoácidos à glândula mamária em decorrência de uma maior gliconeogênese, afetando negativamente o teor de proteína no leite.

O maior teor de gordura no leite para as vacas do tratamento $M$ em relação ao controle, assim como a tendência de maior produção de gordura, são resultados diferentes do observado por outros autores (Duffield et al., 1999; Phipps et al., 1995; Thomas et al., 1993; Sauer et al., 1989). Os efeitos positivos relatados por outros autores sobre produção de gordura no leite, em geral, estiveram associados a um aumento na produção de leite (Beckett et al., 1998), uma vez que os teores de gordura foram mais baixos, porém nem sempre estatisticamente significativos. Lean et al. (1994) observaram tendência para maior produção de gordura no leite apenas para 1 dos 6 rebanhos avaliados, justamente no rebanho que também apresentou resposta em produção de leite. Steen et al. (1996), avaliando os dados de 2168 vacas na Noruega, separaram-nas em três grupos, segundo o nível de corpos cetôniços no leite. Estes autores observaram maior teor de gordura para vacas nos grupos 2 e 3 (maiores teores de corpos cetônicos) em relação ao grupo 1.

Os resultados de outras avaliações que utilizaram PG (Birchen et al., 2000; Formigoni et al., 1996; Studer et al., 1993) foram semelhantes ao observado no presente trabalho, não havendo diferenças em percentual e produção de gordura do leite. Fisher et al. (1973) observaram menor teor de gordura do leite para vacas que receberam $6 \%$ de $P G$, porém o mesmo não foi observado para as vacas que receberam concentrado com 3 e $9 \%$ de PG.

O teor de lactose no leite é amplamente divulgado como constante (Larson, 1985; Linn, 1989), no entanto, algumas práticas nutricionais podem produzir alterações estatisticamente significativas, mas de magnitudes muito pequenas (Sutton, 1990). Poucos foram os trabalhos que avaliaram o efeito do fornecimento de M ou PG sobre o teor de lactose, geralmente, não encontrando efeito (Ramanzin et al., 1997; Sauer et al.; 1973). Fisher et al. (1973) 
observaram teor de lactose superior para vacas que receberam concentrado com $9 \%$ de PG, o que contrasta com o efeito encontrado neste experimento, onde se observou maiores teores para as vacas do tratamento controle.

\subsection{Parâmetros Sanguíneos}

Os dados das Tabelas 09 e 10 demonstram que as vacas encontravamse em condições metabólicas semelhantes no início do experimento, assim como também foram semelhantes os dias médios de coleta entre os tratamentos, descartando assim um possível efeito indesejado, sobretudo no pré-parto, sobre os parâmetros avaliados. Houve uma leve tendência de as vacas do tratamento controle apresentarem atividade plasmática de aspartato aminotransferase (AST) menor antes do início do experimento, aos 35 dias antes da data prevista para o parto (Tabela 10). Esta condição torna-se menos importante dentro da magnitude dos valores encontrados, uma vez que todos os tratamentos apresentaram resultados considerados clinicamente normais. Segundo Kaneko (1989), valores de atividade de AST em bovinos são considerados normais entre 78 a $132 \mathrm{UI} / \mathrm{L}$, bem superior ao encontrado neste experimento. Contudo, outros trabalhos têm encontrado valores semelhantes em atividade de AST (Singh et al., 1997; Mostaghni \& Valadan; 1996; West, 1989). Apesar da utilização de parâmetros sanguíneos para diagnóstico de esteatose hepática ter produzido resultados variáveis, a baixa atividade de AST observada neste experimento nos permite inferir que a infiltração gordurosa no fígado não foi um problema neste rebanho, durante o período avaliado.

Os resultados de glicose plasmática (Tabela 12) mostram que o efeito de tratamento foi dependente do tempo de coleta em relação ao parto. As concentrações foram semelhantes durante a lactação, por outro lado, durante o periodo de fornecimento as vacas que receberam PG apresentaram concentrações significativamente superiores, aos 21 e 3 dias antes do parto, 
comprovando então a habilidade deste composto em produzir hiperglicemia, conforme extensivamente relatado (Grummer et al., 1994; Studer et al., 1993).

As concentrações mais baixas de glicose nos ruminantes e o efeito da fermentação ruminal sobre o alimento tornam o nivel plasmático de glicose extremamente dependente do horário de coleta em relação ao fornecimento do alimento. Possivelmente, este fator tenha sido minimizado, já que as amostras de sangue foram coletadas todas no mesmo horário, antes do fornecimento do alimento.

Studer et al. (1989) observaram aumentos semelhantes de glicose sanguínea ao parto em vacas tratadas com $P G$ e em vacas do grupo controle, enquanto Birchen et al. (2000) encontraram resultado semelhante apenas nas vacas tratadas com PG.

O período periparto é caracterizado por alterações marcantes, algumas de médio prazo, como acontece com as concentrações de AGL no sangue (semanas), outras de mais curto prazo, como é o caso do HC (dias) e ainda alterações de duração bastante reduzida (horas), como é o caso da concentração plasmática de cortisol e progesterona (Tucker, 1985). Portanto, é possivel de se imaginar que vacas coletadas mais próximo ao parto, em função de maior concentração de cortisol, possam apresentar maiores concentrações de glicose, já que este hormônio estimula a gliconeogênese (Dickson, 1988). As amostras do dia do parto, por definição, foram coletadas até 24 horas após a ocorrência do parto propriamente dito. Sendo assim, pode-se sugerir que os resultados de glicose sanguínea ao parto tenham sido influenciados por fatores outros, não relacionados diretamente aos tratamentos propostos, como o tempo de coleta do sangue em relação à ocorrência do parto.

Embora tenha havido apenas uma tendência $(p<0,09)$ para interação tempo $x$ tratamento e um efeito altamente significativo para tratamento $(p<0,007)$ no que se refere a insulina, serão discutidas as diferenças ocorridas nos diferentes tempos. Observando os dados da Tabela 13, nota-se que as 
diferenças ocorridas no período pré-parto foram consideravelmente maiores, enquanto que no período de lactação as concentrações de insulina foram bastante semelhantes entre os tratamentos, o que é coerente, já que todos tratamentos estiveram sob o efeito da monensina sódica durante a lactação. Semelhante ao observado para glicose, as vacas tratadas com PG apresentaram teores de insulina superiores durante o pré-parto, mostrando tendência aos 21, 14 e 3 dias antes do parto $(p<0,09)$. Conforme reportado por outros pesquisadores (Grummer et al., 1994; Studer et al., 1993), a administração oral de PG foi eficiente em produzir aumento nos niveis de glicose e insulina durante o período de fornecimento, porém Christensen et al. (1997) observaram efeito significativo para insulina mas não para glicose.

Em se tratando da utilização de monensina, as alterações no perfil de ácidos graxos voláteis no rúmen, basicamente aumento de propionato (Sauer et al., 1989; Ramanzin et al. 1997) e diminuição de butirato (Green et al., 1999; Ramanzin et al. 1997; Sauer et al., 1989), sugerem um potencial benefício sobre alguns parâmetros sanguíneos importantes, como glicose, insulina, $\beta$ hba e AGL. No entanto, enquanto as respostas em diminuição de $\beta$-hba estão descritas de maneira bastante consistente (Duffield et al., 1998a; Abe et al., 1994; Thomas et al., 1993; Sauer et al., 1989), poucos trabalhos têm avaliado insulina (Van der Werf et al., 1998). Os efeitos sobre diminuição dos níveis de AGL (Thomas et al., 1993) e aumento de glicose (Duffield et al., 1998a) têm sido observados em poucos trabalhos. Os resultados semelhantes de insulina entre M e C, durante o período pré-parto, estão de acordo com o observado por Van der Werf et al. (1998), embora estes autores tenham avaliado a utilização durante o período de lactação. Pode-se especular, assim como ocorreu com glicose, que em função do modo de ação deste aditivo, coletas de sangue após o período de alimentação seriam mais adequadas para visualizar uma possível diferença entre os tratamentos.

Aumentos nos níveis séricos de insulina poderiam ser benéficos a vacas 
no período de transição, em função de sua ação antilipolítica (Holtenius, 1993). Por outro lado, Petterson et al. (1994) relataram diminuição nas respostas a este hormônio em animais gestantes. A dinâmica na concentração plasmática de ácidos graxos livres ( $A G L$ ) nesta avaliação (Tabela 14 e Figura 3) foi semelhante ao descrito por outros trabalhos (Tesfa et al., 1999; Vazquez-Anon et al., 1994; Bertics et al., 1992; Skaar et al., 1989), aumentando gradualmente a medida que se aproxima o parto e apresentando um pico característico no dia do parto.

Neste experimento, o fornecimento de PG mostrou-se eficiente em reduzir os niveis de $A G L$ sanguíneos quando comparado a $M$, porém os valores médios foram semelhantes ao $C$. As diferenças em insulina e AGL no grupo PG, sugerem, que apesar do efeito lipogênico reduzido (Petterson et al., 1994), aumentos de insulina neste período podem diminuir os níveis de AGL no sangue, sugerindo um efeito negativo sobre a mobilização de gordura corpórea. Studer et al. (1993) observaram diminuição significativa de AGL durante o pré-parto e tendência no pós-parto, fornecendo um litro de PG por vaca/d.

A ausência de efeito da monensina nas concentrações plasmáticas de AGL está de acordo com outros trabalhos (Sauer et al. 1989; Abe et al., 1994), sendo que poucos mostraram efeito sobre este parâmetro (Thomas et al., 1993). Stephenson et al. (1997) encontraram efeito no pré-parto, mas não durante a lactação. Ramanzin et al. (1997) observaram tendência para menor AGL sanguíneo apenas em vacas recebendo uma dieta com alto teor de forragem ( $70 \%$ ), não havendo efeito em dietas com $50 \%$ de forragem.

As concentrações de $\beta$-hidroxibutirato ( $\beta$-hba) foram, na média, menores no tratamento PG que nos demais, no entanto, é importante destacar as alterações ocorridas ao longo do tempo, uma vez que houve efeito significativo interação tempo x tratamento (Tabela 15 e Figura 3). Durante todo o período de fornecimento, exceto ao dia 21 pré-parto, as concentrações de $\beta$-hba foram 
inferiores $(p<0,05)$ para as vacas que receberam $P G$ e menores $(p<0,05)$ para as vacas do tratamento controle, aos 14 dias de lactação. Em ruminantes, o butirato absorvido através da mucosa ruminal e os ácidos grãos livres são os principais substratos cetogênicos, porém durante situações de balanço negativo de energia os AGL são predominantes (Zammit, 1990). O aumento de corpos cetônicos no sangue depende, além do aporte de substrato cetogênico, também da disponibilidade de glicose e substâncias gluconeogênicas, de maneira que os AGL e $\beta$-hba possam ser completamente oxidados (Lean et al., 1992). Portanto, a baixa concentração de $\beta$-hba no tratamento $P G$, nada mais é que o espelho da diminuição de AGL e aumento de glicose ocorridos nestas vacas.

\subsection{Incidência de distúrbios metabólicos}

Durante o período experimental, a incidência de distúrbios metabólicos foi reduzida, restringindo-se à ocorrência de cetose subclínica.

Poucos trabalhos têm relatado a incidência de cetose clínica ou subclinica no Brasil (Lago, 1997; Magalhães e Belém, 1995; Castillo et al., 1994). Os resultados obtidos neste experimento (Tabela 16) para os tratamentos C $(13,33 \%)$ e PG $(16,27 \%)$, foram semelhantes aos reportados por Lago (1997) (13,56\%) e Magalhães \& Belém (1995) (18,18\%). Apesar de não haver diferença significativa $(P<0,51)$, as vacas que receberam $M$ a partir do período pré-parto apresentaram $31,08 \%$ de incidência, aproximadamente o dobro do tratamento $C(16,27 \%)$. O pequeno número de animais neste experimento impossibilita avaliar precisamente o efeito dos tratamentos sobre este tipo de parâmetro, porém vem contribuir aos poucos dados disponiveis na literatura sobre a incidência desta patologia em rebanhos nacionais.

Dentre os diversos benefícios em desempenho, atribuídos à utilização de monensina sódica na alimentação de vacas leiteiras, talvez a diminuição na 
concentração de $\beta$-hba e, conseqüentemente, incidência de cetose subclínica seja o mais extensamente relatado na literatura (Green et al., 1999; Duffield 1998b; Abe et al., 1994; Sauer et al., 1989). Abe et al. (1994), possivelmente em função do pequeno número de animais ( $n=16 /$ tratamento), não calcularam os resultados de incidência, enquanto que Sauer et al. (1989) reportaram-nos ( $n=12 /$ tratamento), porém apenas as médias numéricas, sem análise estatística.

Duffield et al. (1998b) avaliaram o fornecimento de monensina sódica a partir do pré-parto, em cerca de 1000 animais, observando uma redução na prevalência de cetose subclínica da ordem de $50 \%$. O tratamento controle chegou a apresentar prevalência superior a $30 \%$, ao parto e na segunda semana de lactação. Green et al. (1999) com um protocolo de fornecimento de monensina sódica semelhante, submeteram os animas a restrição alimentar, entre a terceira e quinta semanas de lactação. Utilizando como limiar de cetose subclínica concentrações plasmáticas de $\beta$-hba superiores a $1200 \mu \mathrm{mol} / \mathrm{L}$, estes autores observaram que ao fim do período de restrição alimentar, a diferença em $\beta$-hba plasmático entre o grupo tratado e o controle foi bem maior que antes da restrição, período em que a concentração média de $\beta$-hba esteve abaixo do limiar estabelecido nas vacas tratadas. Já ao final da quinta semana, a concentração de $\beta$-hba para o grupo tratado foi de $1800 \mu \mathrm{mol} / \mathrm{L}$ e de 2700 $\mu \mathrm{mol} / \mathrm{L}$ no controle.

Estes resultados sugerem que o efeito da monensina sódica sobre a ocorrência de cetose é amplificado, ou mais facilmente detectado, em situações de manejo nutricional impróprio ou de maior demanda energética. Durante este experimento, o percentual de vacas positivas no tratamento controle $(13,33 \%)$ foi semelhante ao observado por Duffield et al. (1998b) no grupo tratado ( \pm 15\%) e ao reportado por Lago (1997) em uma realidade semelhante a esta $(13,56 \%)$. Duffield et al. (1998b) obtiveram produções médias de leite superiores ao observado neste experimento, o que pode também ter 
influenciado seus resultados. No que se refere a cetose subclínica, este experimento não mostrou vantagens da administração de monensina antes do parto em relação ao fornecimento durante a lactação.

Não foi registrado nenhum caso de hipocalcemia clínica, sugerindo que para vacas com este potencial produtivo, recebendo dietas com baixos teores de potássio $(0,995 \%$ da MS) e cálcio $(0,399 \%$ da MS), não há necessidade de utilização de dietas aniônicas no período pré-parto para prevenção de casos clínicos, porém é muito importante certificar-se dos teores de minerais, principalmente dos volumosos, os quais estão sujeitos a maiores variações.

A adição de sais aniônicos é cara e pode provocar problemas de palatabilidade (Horst et al. 1997; Beede, 1992), efeito absolutamente indesejável nesta fase. Segundo Horst et al. (1997) as concentrações de potássio, sódio e, em menor grau, cálcio são importantes determinantes da incidência de febre do leite. Sendo assim, é recomendado não apenas pensar na adição de ânions à dieta, mas também na redução de cátions, principalmente sódio e potássio. Goff \& Horst (1997a) forneceram uma dieta semelhante à utilizada neste experimento, $0,5 \%$ de cálcio e $1,1 \%$ de potássio, não observando casos de febre do leite. $O$ aumento nos teores de potássio $(2,1$ e 3,1\%) esteve relacionado com maior incidência de febre do leite, o mesmo ocorrendo com os teores de cálcio $(1,5 \%)$, porém em menor grau.

\subsection{Parâmetros Reprodutivos}

Não foi encontrado efeito significativo dos tratamentos sobre os parâmetros reprodutivos, a incidência de metrite, retenção de placenta, dias para involução uterina e as patologias ovarianas avaliadas (Tabela 17). Estes resultados são semelhantes aos encontrados por outros autores que avaliaram a utilização de monensina sódica fornecida ao parto (Abe et al., 1994; Lean et al., 1994) ou a partir do pré-parto (Beckett et al., 1998). 
Este experimento avaliou um número muito pequeno de animais, o que pode ter comprometido o poder estatístico do experimento, sobretudo na análise de parâmetros reprodutivos e medidas de incidência. No entanto, trabalhos que avaliaram um grande número de vacas em diferentes rebanhos, também mostraram resultados semelhantes (Beckett et al., 1998; Lean et al., 1994).

Foram encontrados apenas dois trabalhos na literatura consultada que avaliaram o efeito da utilização de PG sobre o desempenho reprodutivo de vacas leiteiras. Formigoni et al. (1996) encontraram menor percentual de vacas em anestro (30 e 58\%) aos 90 dias de lactação para vacas que receberam PG pré e pós-parto. O percentual de vacas em anestro encontrado no experimento anterior é bem superior ao encontrado aos 60 dias de lactação neste experimento, de 6,66 a $23,37 \%$, sugerindo que em situações de manejo adequado, o potencial benefício deste aditivo possa ser pequeno, inviabilizando portanto sua utilização, devido ao alto custo. Laranja da Fonseca et al. (1998) não encontraram efeito significativo em dias para o primeiro cio pós-parto.

A concentração média de progesterona sanguínea (Tabela 18) foi maior para o tratamento $P G(3,50 \mathrm{ng} / \mathrm{ml})$ que para o $C(2,73 \mathrm{ng} / \mathrm{ml})$ no primeiro ciclo estral. No segundo ciclo estral ocorreu justamente o contrário, concentrações superiores para $C(3,74 \mathrm{ng} / \mathrm{ml})$ e inferiores para $P G(3,03 \mathrm{ng} / \mathrm{ml})$. Villa-Godoy et al. (1988) separaram as vacas em quatro categorias, segundo o BE médio do primeiro ao nono dia de lactação. Durante o primeiro ciclo estral, a concentração de progesterona no leite não foi afetada pelo BE médio, mas esteve relacionada no segundo e terceiro ciclo estral. Durante o segundo e terceiro ciclo estral, vacas em BEN severo ( -6 Mcal) tiveram progesterona (área) mais baixa que vacas em $B E$ positivo $(P<0,05)$.

Vasconcelos et al. (1998) observaram que a concentração de progesterona plasmática poderia estar reduzida em vacas com maior consumo 
de MS, sob fornecimento ad libitum e em condições de balanço energético semelhantes. Estes autores ainda sugerem que o aumento no aporte sanguíneo ao fígado em vacas de maior consumo de MS, poderia estar envolvido no processo de depleção de progesterona sanguínea, através do aumento na metabolização deste hormônio pelo fígado. No presente estudo, a ausência de dados de consumo associado a valores similares de $\beta$-hba, AGL e ECC durante a lactação, sobretudo entre estes dois tratamentos (C e PG), impossibilita estabelecer uma relação de causa e efeito precisa.

Embora a equação de regressão relacionando progesterona plasmática e área de corpo lúteo tenha sido altamente significativa, a área de corpo lúteo explicou somente $32 \%$ da variação em progesterona. Quando foi incluído na regressão o dia estimado do ciclo estral, o coeficiente de determinação foi maior, $45 \%$, próximo aos $56 \%$ reportado por Santos, J. (1997).

Son et al. (1995) observaram maior correlação entre área de $\mathrm{CL}$ e progesterona no leite no fim da fase lútea $(77 \%)$ que no início $(73 \%)$, o que sugere um efeito de período da fase lútea sobre a correlação destes parâmetros.

\subsection{Sanidade da Glândula mamária}

Poucos foram os trabalhos que avaliaram o efeito de PG (Formigoni et al., 1996) ou M (Beckett et al., 1998) sobre a saúde da glândula mamária. Os dados de contagem de células somáticas (CCS) estão de acordo com o reportado por Formigoni et al. (1996), os quais encontraram menor valor para vacas tratadas com PG durante o pré e pós-parto. Beckett et al. (1998) não encontraram efeito sobre mastite clínica, embora o acompanhamento não tenha sido tão rigoroso como neste experimento, o que é comum em grandes triagens como aquela.

Apesar do tratamento $\mathrm{C}$ ter apresentado contagem de células somáticas 
superior aos demais, os valores foram próximos a M. Quando se observa os dados de incidência de mastite clínica por quarto e escore médio, não há diferença entre estes dois tratamentos. Vacas que receberam PG apresentaram menor número de quartos clinicamente afetados $(P<0,05)$ e tendência de maior número de quartos classificados como sadios $(P<0,16)$. Estes resultados refletiram em um menor escore médio de mastite clínica nestas vacas (Tabelas 19 e 20).

Apesar de muitas revisões sobre o assunto salientarem a relação entre balanço energético pós-parto, desempenho do sistema imunológico e ocorrência de patologias de origem infecciosa (Mallard et al., 1998; Goff \& Horst, 1997b), poucos são os trabalhos disponiveis na literatura que pesquisaram o efeito direto sobre mastite. Kremer et al. (1993) observaram casos clínicos mais severos em vacas com $\beta$-hidroxibutirato sanguíneo mais alto, quando foram propositadamente infectadas com uma cepa de Escherichia coli. Suriyasathaporn et al. (1999), dividindo os animais em três grupos segundo os níveis plasmáticos de $\beta$-hba, observaram menor quimiotaxia dos leucócitos de vacas com alto teor sanguíneo de $\beta$-hba, comparativamente a vacas do grupo de menor teor.

O tratamento PG apresentou menores concentrações plasmáticas de $\beta$ hba durante o período pré-parto, porém valores semelhantes aos demais durante a lactação. As baixas concentrações de $\beta$-hba, baixa incidência de cetose subclínica e as pequenas diferenças entre tratamentos talvez não sejam suficientes para explicar as grandes diferenças encontradas em incidência de mastite clínica e contagem de células somáticas. Portanto, outros fatores não avaliados neste experimento podem ter influenciado os resultados encontrados. 


\section{CONCLUSÕES}

O fornecimento de propileno glicol ou de monensina sódica durante o pré-parto não mostraram benefícios sobre produção de leite em vacas produzindo em torno de $31 \mathrm{~kg}$ por dia em sistema de confinamento, nem tão pouco sobre o desempenho reprodutivo e incidência de distúrbios metabólicos.

A administração de monensina sódica pré-parto aumentou o teor de gordura do leite e mostrou tendência em aumentar a produção de gordura, enquanto que o teor de proteína do leite foi afetado negativamente.

O propileno glicol mostrou-se um eficiente produto gliconeogênico, aumentando a concentração plasmática de glicose e insulina, assim como diminuindo as concentrações de $\beta$-hidroxibutirato durante o período de fornecimento, o pré-parto. Também foi eficiente em reduzir as concentrações de ácidos graxos livres durante todo período avaliado.

O fornecimento de propileno glicol durante o pré-parto reduziu a contagem de células somáticas e a incidência de mastite clínica.

Esta avaliação não mostrou vantagens em iniciar o fornecimento de monensina sódica no pré-parto, comparativamente ao parto, no que se refere a parâmetros sanguíneos e reprodutivos. 


\section{REFERÊNCIAS BIBLIOGRÁFICAS}

ABE, N.; LEAN, I. J.; RABIEE, A.; PORTER, J.; GRAHAM, C. Effects of sodium monensin on reproductive performance of dairy cattle. II. Effects on metabolites in plasma, resumption of ovarian cyclicity and oestrus in lactating cows. Australian Veterinary Journal, v.71, p.277-282, 1994.

A.O.A.C. Association of Official Analytical Chemists. Official Methods of Analysis. 12. Ed., Washinton, D.C., 1990.

ALVES, M.C. SAS: Estatística Básica. 2.ed. Piracicaba: Centro de Informática do Campus Luiz de Queiroz (USP), /1999/. 53p.

BAGG, R. Mode of action of ionophores in lactating dairy cattle. In: USEFULNESS OF IONOPHORES IN LACTATING DAIRY CATTLE, Canadá: Ontario Veterinary College, 1997. Proceedings. p. 13-21.

BATTOCHIO, M.; GABAI, G.; MOLLO, A.; VERONESI, M.C.; SOLDANO, F.; BONO, G.; CAIROLI, F. Agreement between ultrasonographic classification of the $\mathrm{CL}$ and plasma progesterone concentration in dairy cows. Theriogenology, v.51, p.10591069, 1999.

BAUCHART, D. Lipid absorption and transport in ruminants. Journal of Dairy Science, v.76, p.3864-3881, 1993.

BAUMAN, D.E. Bovine somatotropin and lactation: from basic science to commercial application. Domestic Animal Endocrinology, v.17, p.101-116, 1999.

BAUMAN, D.E.; CURRIE, W.B. Partioning of nutrientes during pregnancy and lactation: $A$ review of mechanisms involving homeostasis and homeorhesis. Journal of Dairy Science, v.62, p.1514-1528, 1980.

BEAM, S.W. Energy balance, follicular growth and first ovulation in postpartum dairy cows. Journal of Dairy Science, v.77, p.127, 1996. Supplement, 1. 
BEAM, S.W.; BUTLER, W.R. Energy balance and ovary follicule development prior to the first ovulation postpartum in dairy cows receiving three levels of dietary fat. Biology of Reproduction, v. 59, p.133-142, 1997.

BEAM, S.W.; BUTLER, W.R. Energy balance, metabolic hormones, and early postpartum follicular development in dairy cows fed prilled fat. Journal of Dairy Science, v. 81, p.121-131, 1998.

BECKETT, S.; LEAN, I.; DYSON, R.; TRANTER, W.; WADE, L. Effects of monensin on the reproduction, health, and milk production of dairy cows. Journal of Dairy Science, v.81, p.1563-1573, 1998.

BEED, D.K.; FARLIN, S.D. Effects of antibiotics on apparent lactate and volatile fatty acid production: in vitro rumen fermentation studies. Journal of Animal Science, v.45, p.385-392, 1977.

BEEDE, D.K. The DCAD concept: Transition rations for dry pregnant cows. Feedstuffs, USA. 26 dez., 1992. p.12-19.

BEKANA, M. Prostaglandin $F_{2 \alpha}$ and progesterone profiles in post-partum cows with short luteal phases. Acta Veterinaria Scandinavica, v.38, p.323-330, 1997.

BELL, A. W. Pregnancy and fetal metabolism. In: FORBES, J.M. Quantitative aspects of ruminant digestion and metabolism. Oxford, U.K., CAB International, 1993.p. 405-418.

BELL, A.W. Regulation of organic nutrient metabolism during transition from late pregnancy to early lactation. Journal of Animal Science, v.73, p.2804-2819, 1995.

BELL, A.W., SLEPETIS, R.; EHRHARDT, R.A. Growth and accretion of energy and protein in the gravid uterus during late pregnancy in Holstein cows. Journal of Dairy Science, v. 78, p.1954-1961, 1995.

BELL, A.W.,RYMPH, M.B.; SLEPETIS, R.; HOUSE, W.A; EHRHARDT, R.A. Growth and accretion of energy and protein in the gravid uterus during late pregnancy in Holstein cows. In: CORNELL NUTRITION CONFERENCE FOR FEED MANUFACTURES, Cornell, 1992. Proceedings. p.102-109.

BELL, A.W.; BAUMAN, D.E. The transition cow: actualized homeorhesis. In: CORNELL NUTRITION CONFERENCE FOR FEED MANUFACTURES, Cornell, 1996. Proceedings. p.150-156.

BERTICS, S.J.; GRUMMER, R.R.; CADORNINGA-VALINO, C.; STODDARD, E.E. Effect of prepartum dry matter intake on liver triglyceride concentration in early lactation. Journal of Dairy Science, v. 75, p.1914-1922, 1992. 
BIRCHEN, M.; FADL-ALLA, B.A.; MURPHY, M.R.; MCCOY, G.C.; HUTJENS, M.F. Metabolic effects of propylene glycol in transition diets of Jersey cows. Journal of Animal Science, v.78, p.253, 2000. Supplement, 1.

BORREBAEK, B.; HALSE, K.; TVEIT, B.; DAHLE; CEH, L. Plasma glucose, ketone bodies, insulin, glucagon and enteroglucagon in cows: Diurnal variations related to ketone levels before feeding and to the ketogenic effects of feed. Acta Veterinaria Scandinavica, v.31, p.5-15, 1990.

BRINDLE, N.P.J.; ZAMMIT, V.A.; POGSON, C.I. Regulation of carnitine palmitoyltransferase activity by malonyl-CoA in mitochondria from sheep liver, a tissue with low capacity of fatty acids synthesis. Biochemical Journal, v.232;p.177-182, 1985.

BRITT, J.H.; SHAW, D.W.; WASHBURN, S.P.; HEDGPETH, S. Endogenous progesterone during the luteal phase before insemination influences embryo recovery in lactating Holstein cows. Journal of Animal Science, v.74, p.225, 1994. Supplement, 1.

BURTON, J.L.; McBRIDE, B.W.; BLOCK, E.; GLIMM, D.R., KENNELLY, J.J. A review of bovine growth hormone. Canadian Journal of Animal Science, v. 74, p.167$201,1994$.

× BUTLER, W.R. Nutritional interactions with reproductive performance in dairy cattle. Animal Reproduction Science, v.60-61, p.449-457, 2000.

BUTLER, W.R.; CALAMAN, J.J.; BEAM, S.W. Plasma and milk urea nitrogen in relation to pregnancy rate in lactating dairy cattle. Journal of Animal Science, v.74, p.858-865, 1996.

BUTLER, W.R.; SMITH, R.D. Interrelationships between energy balance and postpartum reproductive function in dairy cattle. Journal of Dairy Science, v.72, p.767-783, 1989.

BUTLER, W.R.;EVERETT, R.W.; COPPOCK, C.E. The relationships between energy balance, milk production and ovulation in postpartum Holstein cows. Journal of Animal Science, v.53, p.742-748, 1981.

CANFIELD, R.W.; SNIFFEN, C.J.; BUTLER, W.R. Effects of excess degradable protein on postpartum reproduction and energy balance in dairy cattle. Journal of Dairy Science, v.73; p.2342-2349, 1990.

CASTILLO, O.A.C. Aspectos bioquímicos do sangue e do leite de vacas leiteiras no início de lactação. Belo Horizonte, 1994. 77p. Dissertação (mestrado) Universidade Federal de Minas Gerais. 
CEBRA, C.K.; GARRY, F.B.; GETZY, D.M.; FETTMAN, M.J. Hepatic lipidosis in anorectic, lactating Holstein cattle: A retrospective study of serum biochemical abnormalities. Journal of Veterinary Internal Medicine, v.11, p.231-237, 1997.

CHRISTENSEN, J.E., GRUMMER, R.R.; RASMUSSEN, F.E.; BERTICS, E.S.J. Effect of method of delivery of propylene glycol on plasma metabolites of feed-restricted cattle. Journal of Dairy Science, v.80, p.563-568, 1997.

COLLIER, R.J.; DOELGER, S.G.; HEAD, H.H.; THATCHER,W.W.; WILCOX, C.J. Effects of heat stress during pregnancy on maternal hormone concentration, calf birth weight and postpartum milk yield of Holstein cows. Journal of Dairy Science, v.54, p.302-319, 1982.

CURTIS, C.R., ERB, H.N; SNIFFEN, C.J; SMITH, D.; KRONFELD, D.S. Path analysis of dry period nutrition, postpartum metabolic and reproductive disorders and mastitis in Holstein cows. Journal of Dairy Science, v.68, p.2347-2360, 1985.

CZERKAWSKI, J.W.; BRECKENRIDGE, G. Dissimilation of 1,2-propanediol by rumen micro-organism. British Journal of Nutrition, v.29, p.317-330, 1973.

DAVIS, A.J., FLEET, R.; GOODE, J.A.; HAMON, M.H.; MAULE-WALKER, F.M.; PEAKER, M.. Changes in mammary gland function at the onset of lactation in the goat: correlation with hormonal changes. Journal of Physiology, v.288, p.33-41, 1979.

DE VRIES, M.J.; VEERKAMP, R.F. Energy balance of dairy cattle in relation to milk production variables and fetility. Journal of Dairy Science, v.83, p.62-69, 2000.

DERIVAUX, J.; ECTORS, F. Fisiologia de la gestacion y obstetricia veterinaria. Zaragoza: Acribia, 1984. cap. 8, p.99-122: Transtornos de la gestacion

DETILLEUX, J.C.; GROHN, Y.T. Effects of clinical ketosis on test day milk yields in Finnish Ayrshire cattle. Journal of Dairy Science, v. 77, p.3316-3323, 1994.

DETILLEUX, J.C.;GROHN, Y.T.; EICKER, S.W.; QUAAS, R.L. Effects of left displaced abomasums on test day milk yields of Holstein cows. Journal of Dairy Science, v. 80, p.121-126, 1997.

DICKSON, W.M. Glândulas Endócrinas. In: SWENSON, M.J. (Ed.). Dukes: Fisiologia dos animais domésticos. Rio de Janeiro: Guanabara, 1988. cap. 48, p. 659-687.

DIRKSEN, G.U., U.G. LIEBICH E E. MAYER. Adaptative changes of the ruminal mucosa and their functional and clinical significance. Bovine Practice, v.20, p.116-124, 1985.

DOMECQ, J.J., SKIDMORE, A.L.; LLOYD, J.W; KANEENE, J.B. Relationship between body condition scores and conception at first artificial insemination in a large dairy 
herd of high yielding Holstein cows. Journal of Dairy Science,v.80, 113-120, 1997.

DRACKLEY, J.K. Biology of dairy cows during the transition period: the final frontier. Journal of Dairy Science, v. 82, p.2259-2273, 1999.

DRACKLEY, J.K. Nutritional management of dairy cows during the transition period. In: Annual Ruminant Nutrition Symposium, Flórida, E.U.A., 1998a. Proceedings

DRACKLEY, J.K. Transitional period nutrition management explored. Feedstuffs, USA, 9 fev. 1998b. p.12-16.

DUFFIELD, T. F.; LESLIE, K.E.; SANDALS, D.; LISSEMORE, K.; McBRIDE, B.W.;LUMSDEN, J.H.; DICK, P.;BAGG, R. Effect of prepartum administration of monensin in a controlled-release capsule on milk production and milk composnents in early lactation. Journal of Dairy Science, v.82, p.272-279, 1999.

DUFFIELD, T. F.; SANDALS, D.; LESLIE, K.E.; LISSEMORE, K.; McBRIDE, B.W.;LUMSDEN, J.H.; DICK, P.;BAGG, R. Effect of prepartum administration of monensin in a controlled-release capsule on postpartum energy indicators in lactating dairy cows. Journal of Dairy Science, v.81, p.2354-2361, 1998a.

DUFFIELD, T. F.; SANDALS, D.; LESLIE, K.E.; LISSEMORE, K.; McBRIDE, B.W.;LUMSDEN, J.H.; DICK, P.;BAGG, R. Efficience of monesin for the prevention of subclinical ketosis in lactating dairy cows. Journal of Dairy Science, v.81, p.2866-2873, 1998b.

EDMONDSON, A.J., I.J. LEAN, L. WEAVER, T. FARVER E G. WEBSTER. A body condition scoring chart for Holstein dairy cows. Journal of Dairy Science, v.72, p.68-77, 1989.

EDMONDSON, A.J.; FISSORE, I.J.; PHASEN, R.L.; BONDURANT, R.H. The use of ultrasonography for the study of the bovine reproductive tract: I. Normal and pathological ovarian structures. Animal Reproduction Science, v.12, p. 157-165, 1986.

EGER, S.; SHEMESH, M.; SCHINDLER, H.; AMIR, S.; FOOTE, RH. Characterization of short luteal cycles in the early post-partum period and their relation to reproductive performance of dairy cows. Animal Reproduction Science, v.16, p.215-224, 1988.

EMERY, R.S., N. BURG, L.D. BROWN.. Detection, occurrence and prophylatic treatment of borderline ketosis with propylene glycol feeding. Journal. Dairy Science, v.47, p.1074-1079, 1964.

FELLNER, V.; SAUER, F.D.; KRAMER, J.K.G. The effect of ionophores on fatty acid biohydrogenation by rumen bacteria in continous culture. Journal of Dairy Science, v.78, p.268, 1995. Supplement, 1. 
FISHER, L.J.; ERFLE, J.D.; LODGE, G.A.; SAUER, F.D. Effects of propylene glycol or glycerol sukpplementation of the diet of dairy cows on feed intake, milk yield and composition, and incidence of ketosis. Canadian Journal of Animal Science, v.53, p.289-296, 1973.

FORBES, J.M. Voluntary feed intake and diet selection in farm animals. Londres: CAB International, 1995. cap. 9, p.186-203: Reproduction and Lactation.

FORMIGONI, A.; CORNIL, M.C.; PRANDI, A.; MORDENTI, A.; ROSSI, A.; PORTETELLE. D.; RENAVILLE, R. Effect of proprylene glycol supplementation around parturition on milk yield, reproductionperformance and some hormonal and metabolic characteristics in dairy cows. Journal of Dairy Research, v.63, p.11-24, 1996.

GAMA, M.A.S. Efeitos da administração de somatrotopina bovina (BST) e monensina sobre parâmetros produtivos e metabólicos de vacas em lactação. Pirassununga, 2000. 125p. Dissertação (mestrado) - Faculdade de Medicina Veterinária e Zootecnia, Universidade de São Paulo

GERLOFF, B.J.; HERDT, T.H.; EMERY, R.S. Relationship of hepatic lipidosis to health and performance in dairy cattle. Journal of American Veterinary Medicine Association, v.188, p.845-850, 1986.

GOFF, J.P.; HORST, R.L. Physiological changes at parturition and their relationship to metabolic disorders. Journal of Dairy Science, v.80, p.1260-1268, $1997 \mathrm{~b}$.

GOFF, J.P.; HORST, R.L. Oral calcium propionate as treatment for hypocalcemia in dairy cows. Journal of Dairy Science, v.78, p.186-194, 1995.

GOFF, J.P.; HORST, R.L. Effect of addition of potassium and sodium, but not calcium, to prepartum rations on milk fever in dairy cows. Journal of Dairy Science, v.80, p.176- 186, 1997a.

GOFF, J.P.; HORST, R.L.; JARDON, P.W.; BORELLI, C.; WEDAM, J. Field trials of an oral calcium propionate paste as an aid to prevent milk fever in periparturient dairy cows. Journal of Dairy Science, v.79, p.378-383, 1996.

GRAVERT, H.O. Dairy cattle production. Nova York: Elsevier Science, 1987. p.3576 , Breeding of dairy cattle.

GREEN, B.L; McBRIDE, B.W.; SANDALS, D.; LESLIE, K.E.;BAGG, R.;DICK, P. The impact of a monensin controlled-release capsule on subclinical ketosis in the transition dairy cow. Journal of Dairy Science, v.82, p.333-342, 1999.

GRIINARI, J. ; DWYER, M.A.; MCGUIRE, M.A.; BAUMAN, D.E.; PALMQUIST, D.L.; NURMELA, K.V.V. Trans-Octadecenoic acids and milk fat depression in lactating dairy cows. Journal of Dairy Science,v.81, p.1251-1261, 1998. 
GRÖHN, Y.; HEINONEN, K. e LINDBERG, A. L. Fat Infiltration in the liver of Finnish Ayrshire cows during early lactation. Acta veterinaria Scandinavica, v. 28, p. 143$149,1987$.

GRÖHN, Y.T. Interrelationship between milk yield and disease in dairy cows. In: CORNELL NUTRITION CONFERENCE FOR FEED MANUFACTURES, Cornell, 1996. Proceedings. p.158-167.

GRUMMER, R.R. Impact of changes in organic nutrient metabolismon feeding the transition dairy cow. Journal of Animal Science, v.73, p.2820-2833, 1995

GRUMMER, R.R. Transition cow energy, protein nutrition examined. Feedstuffs, USA. 14 sep. 1998. p.11-23.

GRUMMER, R.R.. Etiology of lipid-related metabolic disorders in periparturient dairy cows. Journal of Dairy Science, v.76, p.3882-3896, 1993.

GRUMMER, R.R.; WINKLER, J.C.; BERTICS, S.; STUDER, E.V.A. Effect of propilene glycol dosage during feed restriction on metabolites in blood of prepartum Holstein heifers. Journal of Dairy Science, v.77, p 3618-3623, 1994.

GUARD, C. Metabolic Diseases: A herd Approach. In: REBHUN, W. C.; GUARD, C.; RICHARD, C. M. Diseases of Dairy Cattle. New York: Williams \& Wilkins, 1995. cap. 15 , p. $497-510$.

HART, I. C.; BINES, J. A.; MORANT, S. V.; RIDLEY, J. L. Endocrine control of energy metabolism in the cow: Comparasion of the levels of hormones (prolactin, growth hormone, insulin and thyroxine) and metabolites in the plasma of high- and lowyielding cattle at various stages of lactation. Journal of Endocrinology, v.77, p.333-345, 1978.

HEINONEN, K.; RANTASALMI, K.; ALANKO, M. Milk progesterone samples in identifying cycling cows. Acta Veterinaria Scandinavica, v.29, p.245-248, 1988.

HOLTENIUS, P. Hormonal regulation related to the development of fatty liver and ketosis. Acta Veterinaria Scandinavica. The high-yielding dairy cow: Periparturient disturbances in stomach function, acid-base balance, calcium homeostasis and energy metabolism. v.34, p. 55-60, 1993. Supplement, 89

HORST, R.L., GOFF, J.P.; REINHARDT, T.A.; BUXTON, D.R. Strategies for preventing milk fever in dairy cattle. Journal of. Dairy Science, v.80, p.1269-1280, 1997.

HUTJENS, M.F. Practical approaches to feeding the high producing cow. Animal Feed Science and Technology, v.59, p.199-206, 1996. 
INGVARSTEN, K.L.; ANDERSEN, J.B. Integration of metabolism and intake regulation: A review focusing on periparturient animals. Journal of Dairy Science, v.83, p.1573-1597, 2000.

INTERNATIONAL FEDERATION OF CLINICAL CHEMISTRY, Committee on Standarts, Part2. IFCC Method of Aspartate Aminotransferase. Amsterdam: Elsevier Science, 1984, p.121-130.

JASTER, E.H.; WEGNER, T.N. Beta-Adrenergic receptor involvement in lipolysis of dairy cattle subcutaneous adipose tissue during dry and lactating period state. Journal of Dairy Science, v.64, p.1655-1663, 1981.

JOHNSON, R.B. The treatment of ketosis with glycerol and propylene glycol. Cornell Veterinarian, v.40, p.6-11, 1954.

JORDAN, E.R.; FOURDRAINE, R.H. Characterization of the management practices of the top milk producing herds in the country. Journal of Dairy Science, v.76, p.3247-3256, 1993.

KALSCHEUR, K.F.; TETER, B.B.; PIPEROVA, L.S.; ERDMAN, R.A. Effect of dietary forage level and buffer addition on milk trans fatty acids and duodenal trans fatty acid flow in lactating dairy cows. Journal of Dairy Science, v.80, p.2104-2114, 1997.

KANEKO, J.J. Appendixes. In: KANEKO, J.J. Clinical Biochemistry of Domestic Animals. San Diego, Academic press, 1989. Appendixes, p.877-901.

KENELLY, J.J.; LIEN, K.A.. effect of ionophore supplementation on milk components from lactating cows. In: USEFULNESS OF IONOPHORES IN LACTATING DAIRY CATTLE, Canadá: Ontario Veterinary College, 1997. Proceedings. p. 40-49.

KNAPP, J.R.; FREETLY, H.C.; REIS, B.L.; CALVERT, C.C.; BALDWIN, R.L. Effects of somatotropin and substrates on patterns of liver metabolism in lactating dairy cattle. Journal of Dairy Science, v.75, p.1025-1035, 1992.

KOMARAGIRI, M.V.S.; ERDMAN, R.A. Factors affecting body tissue mobilization in early lactation dairy cows. 1 . Effect of dietary protein on mobilization of body fat and protein. Journal of Dairy Science, v.80, p.929-937, 1997.

KREMER W.D.J.; NOORDHUIZEN-STASSEN, E.N.; GROMMERS, F.J.; SCHUKKEN, Y.H; HEERINGA, R.; BRAND, A. Severity of experimental Escherichia coli mastitis in ketonemic and nonketonemic dairy cows. Journal of Dairy Science, v.76, p.3428-3436, 1993.

KUBE, J.C.; SHIRLEY, J.E.; SMITH, T.D.; FREY, R.A. Effect of monensin supplementation on lactating dairy cows. Journal of Dairy Science, v.71, p.218, 1988. Supplement, 1. 
LAGO, E.P. Avaliação da incidência de cetose em vacas de leite. Piracicaba, 1997. 88p. Dissertação (mestrado) - Escola Superior de Agricultura Luiz de Queiroz, Universidade de São Paulo

LANNA, D.P.D.; HOUSESEKNECHT, K.L.; HARRIS, D.M.; BAUMAN, D.E. Effect of somatotropin treatment on lipogenesis, lipolysis, and related cellular mechanisms in adipose tissue of lactating cows. Journal of Dairy Science, v.78, p.1703-1712, 1995.

LARANJA da FONSECA, L.F.; LUCCI, C.S.; RODRIGUES, P.H.M.; SANTOS, M.V.; LIMA, A.P. Supplementation of propyleneglycol to dairy cows in periparturient period: effects on plasma concentration of BHBA, NEFA and glucose. Journal of Animal Science, v.76, p.320, 1998. Supplement,1.

LARSON, B.L.. Biosynthesis and cellular secretion of milk. In: LARSON, B.L. Lactation. Ames: The lowa State University Press, 1985.cap. 4, p.129-163.

LEAN, I. J.; BRUSS, M. L.; BALDWIN, R. L.; TROUTT, H. F. Bovine ketosis: I. Epidemiology and pathogenesis. Veterinary Bulletin, v.61,1209-1218, 1991.

LEAN, I. J.; BRUSS, M. L.; BALDWIN, R. L.; TROUTT, H. F. Bovine ketosis: II. Biochemistry and prevention. Veterinary Bulletin, v.62,1-14, 1992.

LEAN, I. J.; CURTIS, M.; DYSON, R.; LOWE, B. Effects of sodium monensin on reproductive performance of dairy cattle. I. Effects on conception rates, calving to conception intervals, calving to heat and milk production in dairy cows. Australian Veterinary Journal, v.71, p. 273-277, 1994.

LINN, J. G. Altering the composition of milk through management practice. Feedstuffs, USA., setembro 14, p. 18,1989

MacLACHLAN, N.J.; CULLEN, J.M. Fígado, sistema biliar e pancreas exocrine. In: THOMSON, R.G. Patologia Veterinária Especial. São Paulo:Manole, 1990.cap. 5, p.265-308.

MAGALHÃES, A.C.M.; BELÉM, P.A.D. Estudo preliminary sobre a ocorrência de cetose subclínica em um rebanho leiteiro. $7^{\circ}$ Encontro Nacional de Patologia Veterinária, ANAIS, 1995.

MALLARD, B.A.; DEKKERS, J.C.; IRELAND, M.J.; LESLIE, K.E.; SHARIF, S.; LACEY VANKAMPEN, C.; WAGTER, L.; WILKIE, B.N. Alteration in immune responsiveness during the peripartum period and its ramification on dairy cow and calf health. Journal of Dairy Science, v.81, p.585-595, 1998.

MAPLESDEN, D.D. Propylene glycol in the treatment of ketosis. Canadian Journal of Comparative Medicine and Veterinary Science, v.18, p.287-293, 1954. 
MARKUSFELD, O. Parturition disease complex of the high-yielding dairy cow. Acta Veterinaria Scandinavica. The high-yielding dairy cow: Periparturient disturbances in stomach function, acid-base balance, calcium homeostasis and energy metabolism. v.34, p. 9-15, 1993. Supplement, 89

McNAMARA, J.P. Regulation of adipose tissue metabolism to support lactation. Journal of Dairy Science, v.74, p.706-719, 1991.

McNAMARA, J.P. Regulation of bovine adipose tissue metabolism during lactation. 4 . Dose-responsiveness of epinephrine as altered by stage of lactation. Journal of Dairy Science, v.71, p.643-649, 1988.

MIETTINEN, P.V. Correlation between energy balance and fertility in Finnish dairy cows. Acta Veterinaria Scandinavica, v.32, p.189-196, 1991.

MINOR, D.J.; TROWER, S.L.; STRANG, B.D.; SHAVER, R.D.; GRUMMER, R.R. Effects of nonfiber carbohydrate and niacin on periparturient metabolic status and lactation of dairy cows. Journal of Dairy Science, v.81, p.189-200, 1998.

MOE, P.W. Effects of level of intake on the utilization of diets by dairy cows. Ithaca, 1965. Tese (doutorado) - Cornell University.

MOORBY, J.M.; DEWHURST, R.J.; TWEED, J.K.S.; DHANOA, M.S., BECK, N.F.G. Effects of altering the energy and protein supply to dairy cows during the dry period. 2. Metabolic and hormonal responses. Journal of Dairy Science, v.83, p.1795-1805, 2000.

MOSTAGHNI, K.; VALADAN, M. Pathological and serum enzyme changes in subacute fatty liver syndrome in dairy cattle. Indian Journal of Animal Sciences, v. 66, p.681-684, 1996.

NATIONAL RESEARCH COUNCIL. Nutrient requirements of dairy cattle, 6 ed., Washington, National Academy of Science, 1989. 158p.

O'CALLAGHAN, D.O.; BOLAND, M.P. Nutritional effects on ovulation, embryo development and the establishment of pregnancy in ruminants. Animal Science, v.68, p.299-314, 1999.

OLSSON, S.O. Facts on diseases and feeding in the national Swedish dairy herd. Acta Veterinaria Scandinavica. The high-yielding dairy cow: Periparturient disturbances in stomach function, acid-base balance, calcium homeostasis and energy metabolism. v.34, p. 29-32, 1993. Supplement, 89

OPSOMER, G.; CORYN, M.; DELUYKER, H.; KRUIF, A. An analysis of ovarian dysfunction in high yielding dairy cows after calving based on progesterone profiles. Reproduction of Domestic Animals, v.33, p.193-204, 1998. 
OSTERGAARD, S.; SORENSEN, J.T. A review of the feeding-health-production complex in a dairy herd. Preventive Veterinary Medicine, v.36, p.109-129, 1998.

PAISLEY, L.G.; MICKELSEN, W.D.; ANDERSON, P.B. Mechanisms and therapy for retained fetal membranes and uterine infections of cows: A REVIEW. Theriogenology, v.25, p.353-381, 1986.

PECHOVA, A.; ILLEK, J.; HALOUZKA, R. Diagnosis and control of the development of hepatic steatosis in dairy cow in the postparturient period. Acta Veterinaria Brno, v.66, p.235-243, 1997.

PETTERSON, J.A.; SLEPETIS, R.; EHRHARDT, R.A.; DUNSHEA, F.R; BELL, A.W. Pregnancy but not moderate undernutrition atenuates insulin suppression of fat mobilization in sheep. Journal of Nutrition, v.124, p.2431-2436, 1994.

PHIPPS, R.H.; JONES, B.A.; WILKINSON, J.I.D.; TARRANT, M.E. Effect of monensin on milk production of Friesian dairy cows in the United Kingdom. Journal of Dairy Science, v.78, p.268, 1995. Supplement, 1.

PIERSON, R.A.; GINTHER, O.J. Ultrasonography of the bovine ovary. Theriongenology, v.21, p.495-504, 1984.

PUTNAM, D.E.; VARGA, D.A.; DANN, H.M. Metabolic and production responses to dietary protein and exogenous somatotropin in late gestation dairy cows. Journal of Dairy Science, v.82, p.982-995, 1999.

PUTNAM, D.E.; VARGA, G.A. Protein density and its influence on metabolite concentration and nitrogen retention by Holstein cows in late gestation. Journal of Dairy Science, v.81, p.1608-1618, 1998.

PUTNAM, D.E.; VARGA, G.A. Supplemental protein in close-up rations reviewed. Feedstuffs, USA. 29 set. 1997, p.11-15.

RAJAMAHENDRAN, R.; TAYLOR, C. Characterization of ovarian activity in postpartum dairy cows using ultrasound imaging and progesterone profile. Animal Reproduction Science, v.22, p.171-180, 1990.

RAMANZIN, M.; BAIOLONI, L.; SCHIAVON, S.; BITTANTE, G. Effect of monensin on milk production and efficiency of dairy cows fed two diets differing in forage to concentrate rations. Journal of Dairy Science, v.80, p.1136-1142, 1997.

REID, I.M.; ROBERTS, C.J.; TREACHER, R.J.; WILLIAMS, L.A. Effect of body condition at calving on tissue mobilization, development of fatty liver and blood chemistry of dairy cows. Animal Production, v.43; p.7-15, 1986.

REID, I.M.; ROWLANDS, G.J.; DEW, A.M.; COLLINS, R.A.; ROBERTS, C.J.; MANSTON, $R$. The relationship between post-parturient fatty liver and blood 
composition in dairy cows. Journal of Agriculture Science, Cambridge, v.101, p.473-480, 1983.

REYNOLDS, C.K.; HARMON, D.L.; CECAVA, M.J. Absorption and delivery of nutrients for milk protein synthesis by portal-drained viscera. Journal of Dairy Science, v.77, p.2787-2808, 1994.

REYNOLDS, C.K.; HUNTINGTON, G.B.; TYRREL, H.F.; REYNOLDS, P.J. Net metabolism of volatile fatty acids, $D-\beta$-hydroxibutirate, nonesterified fatty acids, and blood gasses by potal-drained viscera and liver of lactating dairy cows. Journal of Dairy Science, v.71, p.2395-2405, 1988.

REYNOLDS, L.P.; FERRELL, C.L.; ROBERTSON, D.A.; FORD, S.P. Metabolism of the gravid uterus, foetus and utero-placenta at several stages of gestation in cows. Journal of Agriculture Science, Cambridge, v.106, p.437-444, 1986.

RODRIGUES, P.H.M. Efeitos dos níveis de monensina e proporções volumosos/concentrados na ração sobre a utilização dos alimentos e parâmetros da fermentação ruminal em animais ruminantes. Piracicaba, 2000. 169p. Tese (doutorado) - Escola Superior de Agricultura Luiz de Queiroz, Universidade de São Paulo.

RUSSEL, J.B. Mechanisms of action of ionophores. In: CORNELL NUTRITION CONFERENCE FOR FEED MANUFACTURES, Cornell, 1997. Proceedings. p.8892

SANTOS, J.E.P. Effect of degree of fatness prepartum on lactation performance and ovarian activity of early postpartum dairy cows. Tucson, 1996. p.85 Tese (mestrado) - University of Arizona.

SANTOS, J.E.P. Effect of grain processing, protein quality and bST on lactation performance and ovarian activity of dairy cows. Tucson, 1997. p.190 Tese (doutorado.) - University of Arizona.

SANTOS, J.E.P.; AMSTALDEN, M. Effects of nutrition on bovine reproduction. In: ENCONTRO ANUAL DA SOCIEDADE BRASILEIRA DE TRANSFERÉNCIA DE EMBRIÖES (SBTE), XIII, Atibaia-SP, 1998. Arquivos da Faculdade de Veterinária-UFRGS. Porto Alegre-RS, 1998. v.1, p.19-89.

SANTOS, J.E.P.; DePETERS, E.J.; JARDON, P.W.; HUBER, J.T. Effect of prepartum crude protein level on performance of primiparous Holstein cows. Journal of Dairy Science, v.82, p.120, 1999. Supplement, 1.

SANTOS, J.E.P; SANTOS, F.A.P. Novas estratégias no manejo e alimentação de vacas pré-parto. In: PLANEJAMENTO DA EXPLORAÇÃO LEITEIRA, Piracicaba, SP, 1998. Anais do $1^{\circ}$ Simpósio sobre Produção Animal. Brasil: FEALQ, 1998. p.165-214. 
SANTOS, M.V. Correlação entre ácido ascórbico plasmático, contagem de células somáticas no leite e o perfil metabólico de vacas secas e em lactação. Pirassununga, 1998. 97p. Dissertação (mestrado) - Faculdade de Medicina Veterinária e Zootecnia, Universidade de São Paulo.

SAS User's Guide: Statistics, Version 5 Edition, 1991. SAS Inst., Inc., Cary, NC.

SAUER, F.D.; ERFLE, J.D.; FISHER, L.J. Propylene glycol and glycerol as a feed additive for lactating dairy cows: an evaluation of boold metabolic parameters. Canadian Journal of Animal Science, v. 53, p. 265-271, 1973.

SAUER, F.D.; KRAMER, J.K.G.; CANTWELL, W.J. Antiketogenic effects of monensin in early lactation. Journal of Dairy Science, v.72, p.436-442, 1989.

SAVIO, J.D.; BOLAND, M.P.; HYNES, N.; ROCHE, J.F. Resumption of follicular activity in the early postpartum period of dairy cows. Journal of Animal Science, v.70, p.1271-1282, 1990.

SCHELLING, G. T. Monensin mode of action in the rumen. Journal of Animal Science, v.58, p.1518-1527, 1984.

SCHILLO, K.K. Effects of dietary energy on control of luteinizing hormone secretion in cattle and sheep. Journal of Animal Science, v.70, p.1271-1282, 1992.

SIGMA. http://www.sigma-aldrich.com, 2000.

SINGH, S.; PRABHAKAR, S.; GHUMAN, S.P.S. Biochemical and progesterone during lameness and infertility in dairy cows. Indian Journal of Animal Science, v.68, p.557-558, 1998.

SKAAR, T.C.; GRUMMER, R.R.; DENTINE, M.R.; STAUFFACHER, R.H. Seasonal effects on prepartum and postpartum fat and niacin feeding on lactation performance and lipid metabolism. Journal of Dairy Science, v.72, p.2028-2038, 1989.

SNIFFEN, C.J.; O'CONNOR, J.D.; VAN SOEST, P.J.; FOX, D.G.; RUSSEL, J.B. A net carbohydrate and protein system for evaluating cattle diets: II. Carbohydrate and protein availability. Journal of Animal Science, v.70, p.3562-3577, 1992.

SON, C.H.; SCHWARZENBERGER, F.; ARBEITER, K. Relationship between ultrasonographic assessment of the corpus luteum area and milk progesterone concentration during estrous cycle in cows. Reproduction of Domestical Animal, v.30, p.97-100, 1995.

SPICER, L.J.; TUCKER, W.B.; ADAMS, G.D. Insulin-like growth factor-I in dairy cows: Relationships among energy balance, body condition, ovarian activity and estrous behavior. Journal of Dairy Science, v.73, p.929-937, 1990. 
STABENFELDT, G.H.; EDQVIST, L.E. Processos reprodutivos na fêmea. In: SWENSON, M.J. (Ed.). Dukes: Fisiologia dos animais domésticos. Rio de Janeiro: Guanabara, 1988. cap. 49 , p. 689-718.

STAPLES, C.R.; THATCHER, W.W. Interactions between energy, production and reproduction: Today and Tomorrow. In: Bioproducts \& Novus International Technical Dairy Symposium. 1997. Dairy Nutrition \& Production : Today and Tomorrow, 1997. p.15-34.

STAPLES, C.R.; THATCHER, W.W.; CLARK, J.H. Relationship between ovarian activity and energy status during the early postpartum period of high producing dairy-cows. Journal of Dairy Science, v.73, p.938-947, 1990.

STEPHENSON, K.A.; LEAN, I.J.; HYDE, M.L.; CURTIS, M.A.; GARVIN, J.K.; LOWE, L. B. Effects of monensin on the metabolism of periparturient dairy cows. Journal of Dairy Science, v.80, p.830-837, 1997.

STEVENSON, J.S.; BRITT, J.H. Relationships among luteinizing hormone, estradiol, progesterone, glucocorticoids, milk yield, body weight and postpartum ovarian activity in Holstein cows. Journal of Animal Science, v.48, p.570-548, 1979.

STEVENSON, J.S; LAMB, G.C.; HOFFMANN; D.P.; MINTON, M.E. Review: Interrelationships of lactation and postpartum anovulation in suckled and milked cows. Livestock Production Science, v.50, p.57-74, 1997.

STUDER, V.A.; GRUMMER, R.R.; BERTICS, S.J. Effect of prepartum propylene glycol administration on periparturient fatty liver in dairy cows. Journal Dairy Science, v.76, p.2931-3939, 1993.

SURIYASATHAPORN, W.; DAEMEN, A.J.J.M.; NOORDHUIZEN-STASSEN, E.N.; DIELEMAN, S.J.; NIELEN, N.; SCHUKKEN, Y.H. $\beta$-hidroxibutyrate levels in peripheral blood and ketone bodies supplemented in culture media affect the in vitro chemotaxis of bovine leukocytes. Veterinary Immunology and Immunopathology, v.68, p.177-186, 1999.

SUTTON, J.D. Altering milk composition by feeding. Journal of Dairy Science, v.72, p.2801-2814, 1989.

TESFA, A.T.; TUORI, M.; SYRJALA-QVIST, L.; POSO, R.; SALONIEMI, H.; HEINONEN, K.; KIVILAHTI, K.; SAUKKO, T.; LINDBERG, L.-A. The influence of dry period feeding on liver fat and postpartum performance of dairy cows. Animal Feed Science and Technology, v.76, p.275-295, 1999.

THATCHER, W.W.; WILCOX, C.J. Postpartum estrous cycle as and indicator of reproductive status in the dairy cow. Journal of Dairy Science, v.56, p.608-610, 1973. 
THOMAS, E.E.; POE, S.E.; McGUFFEY, R.K.; MOWREY, D.H.; GREENFIELD, I.N.; ALLRICH, R.D. The effect of feeding monensin to dairy cows on milk production and serum metabolites during early lactation. Journal of Dairy Science, v.76, p.280, 1993. Supplement, 1.

TUCKER, A.H. Endocrine and neural control of the mammary gland. In: LARSON, B.L. Lactation. Ames: The lowa State University Press, 1985.cap. 2, p.39-79.

VAN DER WERF, J.H.J.; JONKER, L.J.; OLDENBROEK, J.K. Effect of monensin on milk production by Holtein and Jersey cows. Journal of Dairy Science, v.81, p.427-433, 1998.

VAN SAUN, R.J., IDLEMAN, S.C.; SNIFFEN, C.J. Effect of undegradable protein amount fed prepartum on postpartum production in first lactation Holstein cows. Journal of Dairy Science, v.76, p.236-244, 1993.

VAN SAUN, R.J.; SNIFFEN; C.J. Nutritional management of the pregnant dairy cow to optimize health, lactation and reproductive performance. Animal Feed Science and Technology, v.59, p.13-26, 1996.

VAN SOEST, P.J. Nutritional ecology of the ruminant. Ithaca: Cornell University Press, 1994. cap.15, p.230-252: Function of ruminant forestomach.

VAN SOEST, P.J.; ROBERTSON, J.B.; LEWIS, B.A. Methods for dietary fiber, neutral detergent fiber, and nonstarch polysaccharides in relation to animal nutrition. Journal of Dairy Science, v.74, p. 3583. 1991.

VANDEHAAR, M.J.; YOUSIF, G.; SHARMA, B.K.; HERDT, T.H.; EMERY, R.S.; ALLEN, M.S.; LIESMAN, J.S. Effect of energy and protein density of prepartum diets on fat and protein metabolism of dairy cattle in the periparturient period. Journal of Dairy Science, v.82, p.1282-1295, 1999.

VARGA, G.A.; VALLIMONT, J.E. Protein, energy needs of the dry cow explored. Feedstuffs, USA. 14 fev., 2000. p.12-16

VASCONCELOS, J.L.M.; KIMBERLY, K.; TSAI, S.J.; WECHSLER, F.S.; WILTBANK, M.C. Relationship between energy balance and luteal function in lactating dairy cows. Journal of Dairy Science, v.80, p.226, 1998. Supplement, 1.

VAZQUEZ-ANON, M.; BERTICS, S.; LUCK, M.; GRUMMER, R. R. Peripartum liver triglyceride and plasma metabolites in dairy cows. Journal of Dairy Science, v.77, p.1521-1528, 1994.

VAZQUEZ-ANON, M.; GRUMMER, R. R.; BERTICS, S. e STAUFFACHER, E. R. Changes in adipose tissue responsiveness to insulin and estradiol-17 beta in periparturient dairy cattle. Journal of Dairy Science, v.79, p.168, 1996. Supplement, 1. 
VILLA-GODOY, A.; HUGHES, T. L.; EMERY, R. S.; CHAPIN, L. T. e FOGWELL. Association between energy balance and luteal function in lactating dairy cows. Journal of Dairy Science, v.71, p.1063-1072, 1988.

WALDO, D.R.; SCHULTZ, L.H. Blood and rumen changes following the intraruminal administration of glycogenic materials. Journal of Dairy Science, v.43, p.496-505, 1960.

WEST, H.J. Effect on liver function of acetonaemia and the fat cow syndrome in cattle. Research in Veterinary Science, v.48, p.221-227, 1990.

WEST, H.J. Liver function of dairy cows in late pregnancy and early lactation. Research in Veterinary Science, v.46, p.231-237, 1989.

WILLIANSON, D.H.; MELANBY, J.; KREBS, H.A. Enzymatic determination of D(-)-bhydroxibutiric acid and acetoacetic acid in blood. Biochemistry Journal, v.82, p.90-96, 1962.

XU, S.; HARRISON, J.H.; CHLUPA, W.; SNIFFEN, C.; JULIEN, W.; SATO, H.; FUJIEDA, T.; WATANABE, K.; UEDA, T.; SUZUKI, H. Journal of Dairy Science, v.81, p.1062-1077, 1998.

YOUNGQUIST, R.S. Moléstias do Sistema Reprodutivo. In: SMITH, B.P. Tratado de Medicina Interna de Grandes Animais, II. São Paulo:Manole, 1994. cap. 41, p.1351-1363.

ZAMMIT, V.A. Ketogenisis in the liver of ruminants - adaptation to a challenge. Journal of Agriculture Science, Cambridge, v.115, p.155-162, 1990.

ZAMMIT, V.A. Role of insulin in hepatic fatty acid partitioning: emerging concepts. Biochemical Journal, v.314, p.1-14, 1996.

ZUREK, E.; FOXCROFT, G.R.; KENELLY, J.J. Metabolic status and interval to first ovulation in postpartum dairy cows. Journal of Dairy Science, v.78, p.1909-1920, 1995. 